\title{
PALEOTECTONIC AND PALEOGEOGRAPHIC CONDITIONS FOR THE ACCUMULATION OF THE LOWER RIPHEAN AI FORMATION IN THE BASHKIR UPLIFT (SOUTHERN URALS): THE TERRANECHRONE ${ }^{\circledR}$ DETRITAL ZIRCON STUDY
}

\author{
T. V. Romanyuk ${ }^{1,2,3}$, N. B. Kuznetsov ${ }^{4,1,2,3}$, E. A. Belousova ${ }^{3}$, \\ V. M. Gorozhanin ${ }^{5,6}$, E. N. Gorozhanina ${ }^{5}$ \\ ${ }^{1}$ O.Yu. Schmidt Institute of Physics of the Earth of RAS, Moscow, Russia \\ 2 I.M. Gubkin Russian State University of Oil and Gas (National Research University), Moscow, Russia \\ ${ }^{3}$ Australian Research Council Centre of Excellence for Core to Crust Fluid Systems/GEMOC, \\ Department of Earth and Planetary Sciences, Macquarie University, Sydney, Australia \\ ${ }^{4}$ Geological Institute of RAS, Moscow, Russia \\ ${ }^{5}$ Institute of Geology of the Ufa Federal Research Centre of RAS, Ufa, Russia \\ ${ }^{6}$ Bashkir State University, Ufa, Russia
}

\begin{abstract}
The TerraneChrone ${ }^{\circledR}$ (LA-ICP-MS) technique has been applied to carry out an integrated study of detrital zircons in sandstones sampled from the basal horizons of the stratotypical Riphean sequence in the Southern Urals, specifically the Navysh and Chudin suites of the Ai Formation of the Burzyan Group in the Bashkir Uplift. The concentrations of trace elements in the detrital zircons suggest that the role of oceanic or marginal-marine complexes among the primary sources of zircons was insignificant, and show a better agreement with the intra-continental rather than passive-margin origin of the Riphean basin, whose basal levels are composed by the Ai Formation. The U/Pb ages of zircons from samples K13-206 and M08-16-1 are generally similar: the Paleoproterozoic zircons predominate (the dominant peaks are actually coincident, 2063 and $2055 \mathrm{Ma}$ ), and only a few grains of the Archean age are present. Despite the similar $\mathrm{U} / \mathrm{Pb}$ ages of the detrital zircons, these two samples considerably differ in their Hf isotopic features and the concentrations of trace elements, which means that the zircons in the studied sandstones are of different geodynamic origin. The characteristics of these zircons can be explained by a model showing the Ai Formation in the Navysh graben that is a rift structure and a predecessor of the Kama-Belaya aulacogene in the inner Volga-Ural region of the Paleoproterozoic supercontinent Columbia. At the initial stage of rifting, the granitoid complexes with a lower total silicic acidity, which composed the graben walls, had been eroded; as a result of erosion, coarse clastic
\end{abstract}

\section{RESEARCH ARTICLE}

Handling Editor: D.P. Gladkochub

Received: November 1, 2017

Revised: February 10, 2018

Accepted: February 20, 2018

For citation: Romanyuk T.V., Kuznetsov N.B., Belousova E.A., Gorozhanin V.M., Gorozhanina E.N., 2018. Paleotectonic and paleogeographic conditions for the accumulation of the Lower Riphean Ai Formation in the Bashkir Uplift (Southern Urals): the TerraneChrone ${ }^{\circledR}$ detrital zircon study. Geodynamics \& Tectonophysics 9 (1), 1-37. doi:10.5800/GT-2018-9-1-0335.

Для цитирования: Романюк Т.В., Кузнецов Н.Б., Белоусова Е.А., Горожанин В.М., Горожанина Е.Н. Палеотектонические и палеогеографические обстановки накопления нижнерифейской айской свиты Башкирского поднятия (Южный Урал) на основе изучения детритовых цирконов методом «TerraneChrone ${ }^{\circledR}$ » // Геодинамика и тектонофизика. 2018. T. 9. № 1. C. 1-37. doi:10.5800/GT-2018-9$1-0335$.

On-line supplementary materials: Samples analysis data (samples_analysis_data.zip)

Дополнительные материалы (on-line): Данные анализа проб (samples_analysis_data.zip) 
rocks accumulated within the Navysh graben and formed the Navysh suite. A specific "carbonatitic" complex containing zircons (about 2.0, 2.5, 2.85 and $3.6 \mathrm{Ga}$ ) and the Palaeoarchean crustal material in the substrate of their parent rocks was also eroded. In the final stage of rifting, already at the initial stages of the development of the Kama-Belaya aulacogen (Chudin suite), the erosion products from the paleo-aquifers occupying vast areas began to be transported into the rift. The primary sources of clastics for the Chudin suite were both granitoids of the lower and normal silicic acidity. Besides, a specific "carbonatitic" complex containing juvenile zircons (about $2.05 \mathrm{Ga}$ ) was eroded. However, by that time, significant areas of the Archaean basement of the Volga-Ural region might have become hidden underneath a proto-cover and thus not eroded, so the Archean detritus in the Chudin suite is poorly represented in comparison with the Navysh suite, considering both the amounts and ages of detrital zircons. As of today, the Precambrian carbonatite rocks within both the Taratash complex (composing the basement of the Navysh graben) and the southeastern segment of the East-European Platform have not yet been described. The source of the "carbonatite" zircons remains unknown and can be discovered as more and more data on the basement rocks is accumulated.

Key words: Bashkir uplift; Lower Riphean; detrital zircons; TerraneChrone ${ }^{\circledR}$ technique; Navysh graben; Kama-Belaya aulacogen; carbonatites; supercontinent Columbia

\title{
ПАЛЕОТЕКТОНИЧЕСКИЕ И ПАЛЕОГЕОГРАФИЧЕСКИЕ ОБСТАНОВКИ НАКОПЛЕНИЯ НИЖНЕРИФЕЙСКОЙ АЙСКОЙ СВИТЫ БАШКИРСКОГО ПОДНЯТИЯ (ЮЖНЫЙ УРАЛ) НА ОСНОВЕ ИЗУЧЕНИЯ ДЕТРИТОВЫХ ЦИРКОНОВ МЕТОДОМ «TERRANECHRONE ${ }^{\circledR} »$
}

\author{
Т. В. Романюк ${ }^{1,2,3}$, Н. Б. Кузнецов ${ }^{4,1,2,3}$, Е. А. Белоусова 3 , \\ В. М. Горожанин ${ }^{5,6}$, Е. Н. Горожанина 5
}

${ }^{1}$ Институт физики Земли им. О.Ю. Шмидта РАН, Москва, Россия

2 Российский государственный университет нефти и газа (национальный исследовательский университет) им. И.М. Губкина, Москва, Россия

3 Университет Маквори / центр CCFS/GEMOK, Сидней, Австралия

${ }^{4}$ Геологический институт РАН, Москва, Россия

${ }^{5}$ Институт геологии УФимского научного центра РАН, УФа, Россия

${ }^{6}$ Башкирский государственный университет, Уфа, Россия

\begin{abstract}
Аннотация: В статье представлены результаты комплексного изучения по методике «TerraneChrone ${ }^{\circledR}$ » (LA-ICP-MS) детритных цирконов, выделенных из песчаников, слагающих базальные горизонты (навышская и чудинская подсвиты айской свиты бурзянской серии Башкирского поднятия) стратотипического разреза рифея на Южном Урале. Зафиксированные в цирконах содержания элементов-примесей свидетельствуют о малой роли комплексов океанического или окраинно-морского генезиса среди первичных источников цирконов и лучше согласуются с внутриконтинентальным, а не окраинно-континентальным расположением рифейского бассейна, базальные уровни которого выполнены айской свитой. U/Pb возрастные характеристики изученных цирконов в обеих пробах в общем схожи: преобладают палеопротерозойские цирконы (доминирующие пики фактически совпали - 2063 и 2055 млн лет), а архей представлен только немногочисленными зернами. При схожести U/Pb возрастных параметров детритных цирконов по Hf-изотопным признакам этих цирконов и содержаниям в них элементов-примесей зафиксированы существенные различия между пробами, свидетельствующие о том, что источниками цирконов для изученных песчаников были различные по геодинамической природе комплексы. Особенности характеристик цирконов в изученных пробах могут быть объяснены в рамках модели формирования айской свиты в рифтовой структуре - Навышском грабене предшественнике Камско-Бельского авлакогена во внутренней волго-уральской части палеопротерозойского суперконтинента Колумбия. На начальной стадии рифтогенеза в Навышском грабене накапливались грубообломочные породы (навышская подсвита), представляющие собой продукты размыва слагающих борта этого грабена гранитоидных комплексов пониженной валовой кремнекислотности. В размыв попал также комплекс, содержащий специфические «карбонатитовые» цирконы с возрастом около 2.0, 2.5, 2.85 и 3.6 млрд лет и с участием палеоархейского корового материала в субстрате материнских по отношению к ним пород. В завершающую стадию рифтогенеза, уже на начальных стадиях развития Камско-Бельского авлакогена (чудинская подсвита), в грабен стали попадать эрозионные продукты с палеоводосборов, занимающих более обширные площади, первичными источниками кластики для которых были гранитоиды как пониженной, так и нормальной кремнекислотности. В размыв попал также комплекс, содержащий специфические юве-
\end{abstract}


нильные «карбонатитовые» цирконы с возрастом около 2.05 млрд лет. Однако к этому времени значительные площади архейского фундамента Волго-Уралии, вероятно, были покрыты проточехлом и не дренировались, поэтому архейский детрит в навышской подсвите представлен скуднее по сравнению с чудинской подсвитой и по количеству, и по возрастным группам. До сих пор докембрийские карбонатитовые породы ни в тараташском комплексе, слагающем фундамент Навышского грабена, ни в юго-восточной части ВосточноЕвропейской платформы не описаны, и вопрос об источнике этих «карбонатитовых» цирконов остается открытым, но имеет перспективу быть решенным по мере накопления данных о фундаменте.

Ключевые слова: Башкирское поднятие; нижний рифей; детритовые цирконы; методика «TerraneChrone ${ }^{\circledR} » ;$ Навышский грабен; Камско-Бельский авлакоген; карбонатиты; суперконтинент Колумбия

\section{1. ВВЕДЕНИЕ}

На юге Западного Урала расположен обширный выход докембрийских пород (рис. 1), описываемый обычно как Башкирский антиклинорий [Puchkov, 2010; Maslov, 2004]. В его строении выделены две крупные тектонические единицы, разграниченные Зюраткульским разломом [Kuznetsov, 2009].

К западу от Зюраткульского разлома (в пределах западного крыла и осевой части Башкирского антиклинория) распространены фактически не метаморфизованные преимущественно осадочные (карбонатные, глинистые и обломочные) породы верхнего докембрия, которые с резким несогласием налегают на глубоко и неоднократно метаморфизованные раннедокембрийские породы тараташского гранито-метаморфического комплекса. Верхи верхнедокембрийского разреза в западной части Башкирского антиклинория с параллельным несогласием перекрыты палеозойскими толщами [Puchkov, 2010, Kuznetsov et al., 2014b, 2016 и ссылки в этих работах]. К востоку от Зюраткульского разлома (обычно эта часть Башкирского антиклинория рассматривается как его восточное крыло) распространены в разной степени (часто весьма существенно) метаморфизованные вулканогенные, вулканогенно-осадочные и осадочные образования верхнего докембрия, которые с резким несогласием перекрыты палеозойскими отложениями [Puchkov, 2010].

Далее мы будем называть ту часть Башкирского антиклинория, которая расположена к западу от Зюраткульского разлома, Башкирским поднятием (БП). Нижняя, значительная по стратиграфическому объему, часть верхнедокембрийских разрезов БП рассматривается как сводная стратотипическая (эталонная) последовательность рифея, в которой выделяются три серии (снизу вверх) - бурзянская, юрматинская и каратауская [Keller, Chumakov, 1983; Semikhatov et al., 2009; Puchkov, 2010; Maslov, 2004]. Эти серии являются эталонами (стратотипами) соответственно нижнего, среднего и верхнего рифея
Общей стратиграфической шкалы России [Sokolov, Zhamoida, 2002]. Нижнерифейская бурзянская серия наиболее полно представлена в северной части БП. Здесь на крыльях Тараташской антиклинали (в ядре которой на современную дневную поверхность выступает архейско-раннепротерозойский тараташский метаморфический комплекс) с резким несогласием и базальными конгломератами в основании залегает айская свита. Айская свита подразделяется на три подсвиты - навышскую, чудинскую и кисеганскую [Stratigraphic Schemes..., 1993]. В верхах разреза навышской подсвиты М.И. Гарань выделил липовскую толщу аркозовых песчаников мощностью до 100 м.

В статье приведены результаты комплексного изучения детритовых цирконов из чудинских песчаников айской свиты (проба К13-206, публикуются впервые), а также результаты изучения цирконов из навышских песчаников айской свиты (проба М0816-1), пилотные данные по изучению которых кратко опубликованы ранее в работах [Kuznetsov et al., 2013; Romanyuk et al., 2014]. Основная цель исследований - реконструкция геодинамической и палеогеографической обстановки на восточной (уральской) периферии Восточно-Европейской платформы (ВЕП) на момент формирования здесь айской свиты, а также тестирование представлений о возрасте и природе нижних уровней типового разреза рифея и получение информации о питающих провинциях, продуктами разрушения которых сложены песчаники самых низов рифея.

\section{2. ЛИТОЛОГИЧЕСКАЯ ХАРАКТЕРИСТИКА ПОРОД АЙСКОЙ СВИТЫ, СТРАТИГРАФИЧЕСКАЯ И ГЕОГРАФИЧЕСКАЯ ПРИВЯЗКА ПРОБ}

Для подстилающих айскую свиту кристаллических пород тараташского комплекса известны изотопные датировки, попадающие в основном в диапазон 1.78-2.70 млрд лет (см. сводки в работах 


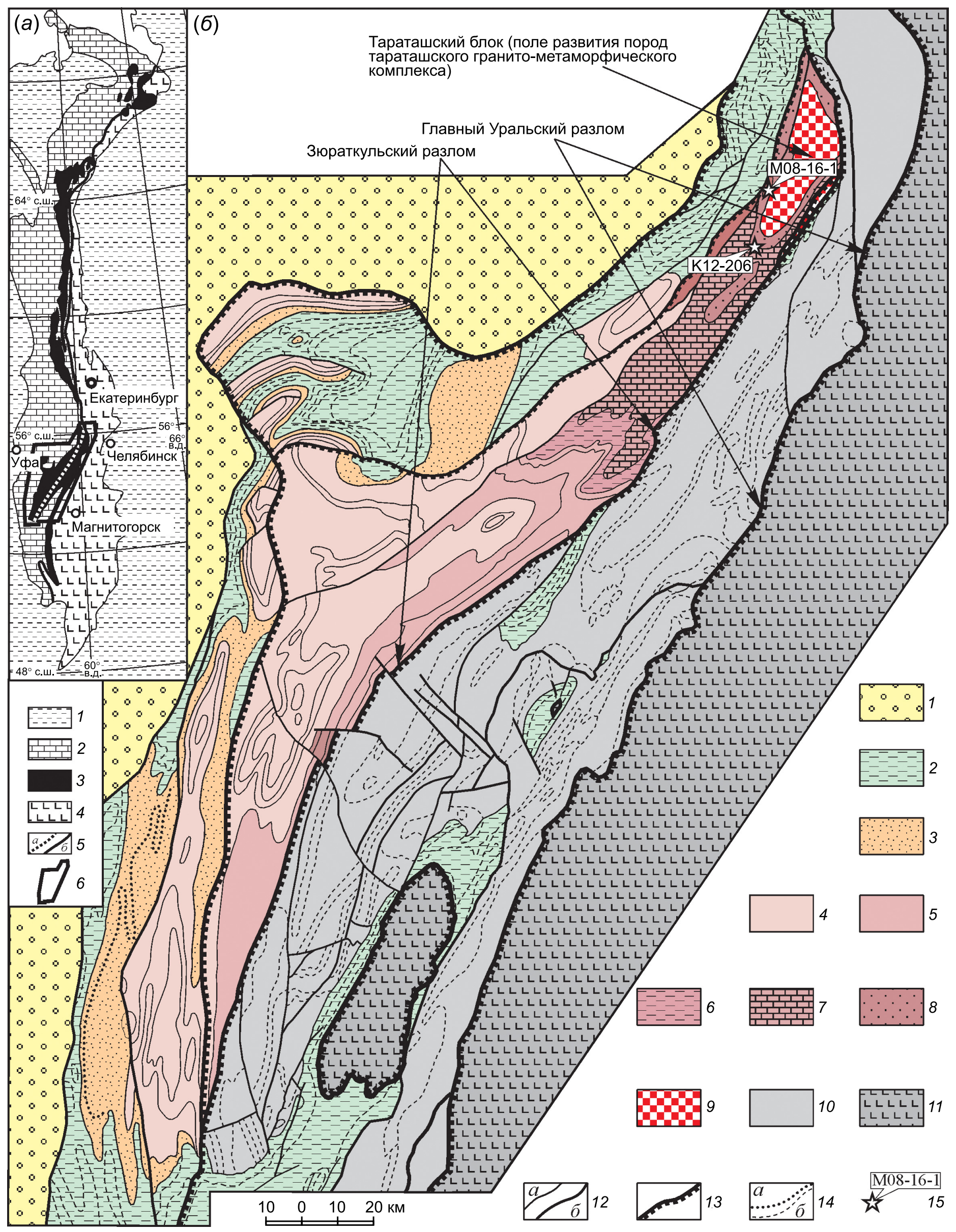


Рис. 1. Положение Башкирского поднятия в структуре Урала (a) и его внутреннее строение (б).

Схема (a): 1 - мезозойско-кайнозойский чехол Восточно-Европейской платформы, Печорской, Прикаспийской и Западно-Сибирской плит; 2-3 - Западно-Уральская мегазона; 2 - ордовикско-позднепалеозойские комплексы, 3 - доордовикские комплексы (протоуралиды-тиманиды зоны Центрально-Уральских поднятий); 4 - Восточно-Уральская мегазона; 5 - Зюраткульский разлом (а) и Главный Уральский разлом (б); 6 - контур геологической схемы (б). Схема (б): 1 - позднепалеозойские комплексы, выполняющие Предуральский краевой прогиб; 2-6 - докембрийские и палеозойские комплексы Западно-Уральской мегазоны: 2 - фаунистически охарактеризованные палеозойские толщи, 3-8 - нижнепалеозойские и докембрийские комплексы Башкирского поднятия: 3 - верхневендско-кембрийская ашинская серия, 4-8 - рифейские толщи стратотипической местности; 4 - верхний рифей (каратауская серия), 5 - средний рифей (юрматинская серия); 6-8 - нижний рифей (бурзянская серия): 6 - бакальская свита, 7 - саткинская свита, 8 - айская свита; 9 - раннедокембрийские метаморфические образования (тараташский комплекс); 10 - неравномерно метаморфизованные палеозойские и допалеозойские комплексы поднятия восточного борта Башкирского антиклинория и Уралтау; 11 - ранне- и среднепалеозойские комплексы Восточно-Уральской мегазоны и краевых аллохтонов (Кракинского и Тирлянского); 12 - разломы: а - нарушающие внутреннее строение тектонических элементов района, б - разграничивающие тектонические единицы в пределах зоны Уралтау; 13 - сместители крупных надвигов и подошвы шарьяжей; 14 - структурные линии: а - границы серий, свит, пачек в пределах показанных комплексов, б - положение куккараукских конгломератов в пределах поля развития пород ашинской серии; 15 - места отбора проб и их номера. Схема составлена с использованием материалов В.И. Козлова (мелкомасштабная геологическая карта, лист Уфа), а также иллюстраций из работ [Puchkov, 2010; Keller, Chumakov, 1983; Kuznetsov et al., 2013, 2014a].

Fig. 1. The Bashkir Uplift: its position in the structure of the Urals (a), and the internal structure (б).

Schematic map (a): 1 - Mesozoic-Cenozoic cover of the East European platform, Pechora, Precaspian and West Siberian plates; 2-3 - West Ural megazone: 2 - Ordovician - Late Paleozoic complexes, 3 - pre-Ordovician complexes (protouralides-tymanides of the Central Ural uplift zone); 4 - East Ural megazone; 5 - Zyuratkul (a) and Main Ural (б) faults; 6 - contour of the geological scheme (б). Geological scheme (б): 1 - Late Paleozoic complexes of the Pre-Ural marginal trough; 2-6 - Precambrian and Paleozoic complexes of the West Ural megazone: 2 - fauna-characterized Paleozoic strata, 3-8 - Lower Paleozoic and Precambrian complexes of the Bashkir Uplift: 3 - Upper Vendian - Cambrian Asha group, 4-8 - Riphean strata of the stratotype area: 4 - Upper Riphean (Karatau group), 5 - Middle Riphean (Jurmat group); 6-8 - Lower Riphean (Burzyan group): 6- Bakal formation, 7 - Satka formation, 8 - Ai formation; 9 - Early Precambrian metamorphic rocks (Taratash complex); 10 - unevenly metamorphosed Paleozoic and pre-Palaeozoic complexes in the uplift located at the eastern side of the Bashkir anticlinorium and Uraltau; 11 - Early and Middle Paleozoic complexes of the East Ural megazone and marginal allochthons (Kraki and Tirlyian); 12 - faults: a - disturbing the internal structure of the regional tectonic elements; $\sigma$ - bordering the tectonic units within the Uraltau zone; 13 - large thrusts and overthrusts; 14 - structural lines: a - boundaries of the rock groups, formations, suites and strata within the complexes; 6 -positions of the Kukkarauk conglomerates within the field of development of the Asha rocks; 15 - sampling sites and their numbers. This scheme uses the data from V.I. Kozlov's small-scale geological map (Ufa sheet) and figures in [Puchkov, 2010; Keller, Chumakov, 1983; Kuznetsov et al., 2013, 2014a].

[Tevelev et al., 2015, 2017]), а по некоторым оценкам достигающие значений 3.5 млрд лет [Ronkin et al., 2012]. Трансгрессивное налегание пород навышской подсвиты на тараташский комплекс надежно установлено по результатам изучения горных выработок, дорожных выемок и скважин. Детальная характеристика разрезов навышской подсвиты айской свиты приведена в статье [Gorozhanin et al., 2014]. Песчаники и конгломераты навышской подсвиты имеют признаки субконтинентального мелководного генезиса. Вулканогенные породы представлены лавами и лавовыми брекчиями, с прослоями крупно- и среднеобломочных туфов; субвулканические породы - дайками диабазов, реже дацитов [Tevelev et al., 2014]. Долгое время считалось (см. обзор [Khotylev, Tevelev, 2017]), что присутствующие в составе нижней части айской свиты (в навышской подсвите) вулканические породы имеют вендский возраст, затем был получен изотопный возраст $1615 \pm 45$ млн лет [Krasnobaev et al., 1992], однако сейчас для них появились и более древние $\mathrm{U} / \mathrm{Pb}$ датировки по цирконам из этих вулканитов - 1752 \pm 18 млн лет [Krasnobaev et al., 2013], которые ограничивают минимальный возраст айской свиты.

Песчано-гравийно-конгломератовая ассоциация основания навышской подсвиты айской свиты отнесена к фации подножий склонов и прибрежных полос. Гравийно-песчаные осадки отнесены к фации русел равнинных рек. Песчаники с косой однонаправленной слоистостью с алевритоглинистыми прослоями рассматриваются как пойменные образования. Светло-серые среднезернистые песчаники липовской толщи, слагающей верхи разреза навышской подсвиты, характеризуются косой слоистостью и наличием линз крупнозернистого и гравийного материала. Эта ассоциация пород формировалась в условиях прибрежно-аллювиальной равнины [Gorozhanin et al., 2014 и ссылки в этой работе]. Залегающая выше чудинская подсвита сложена конгломератами, песчаниками, алевролитами с прослоями углеродистых глинистых сланцев. Кисеганская подсвита (верхи разреза айской свиты) представлена углеродисто-глинистыми сланцами (углеродистыми алевроаргиллитами) с редкими прослоями алевропесчаников [Semikhatov, 1989]. 
T.V. Romanyuk et al.: Paleotectonic and paleogeographic conditions for the accumulation of the Lower Riphean Ai Formation...

Эти породы маркируют собой начало стадии погружения бассейна и трансгрессии.

Проба М08-16-1 (начальный вес 1.5 кг) отобрана из базальных уровней разреза навышской подсвиты в расчистке (в точке с координатами $55^{\circ} 32^{\prime} 34.74 " \mathrm{C}$ и 5941'54.84"В), расположенной на левом борту руч. Черного (правый приток р. Бол. Арша) и вскрывающей средне- и крупнозернистые олигомиктовые песчаники с заметной примесью лититовой компоненты. Проба К13-206 (начальный вес 1.5 кг) отобрана из среднезернистых песчаников чудинской («ефремовской» согласно работе [Semikhatov, 1989]) подсвиты айской свиты (в точке с координатами 55²1'56.77"С и 59³4'47.78"В) в юго-восточной части карьера, расположенного к северу от дороги Куса - Магнитка (в 2170 м к востоку от северо-восточного выезда из пос. Кусинские печи) на правом борту долины р. Бол. Навыш, невдалеке от места ее впадения в р. Куса.

\section{3. ТЕХНОЛОГИЯ ВЫДЕЛЕНИЯ ДЕТРИТОВЫХ ЦИРКОНОВ И МЕТОДИКА ИХ ИЗУЧЕНИЯ}

Методика «TeraneChrone ${ }^{\circledR}$ » состоит в изучении in situ и совместном анализе следующих трех характеристик индивидуальных зерен цирконов:

- U/Pb-изотопной системы циркона, что позволяет установить возраст кристаллизации циркона;

- Lu/Hf-изотопной системы циркона, что позволяет оценивать $\varepsilon_{\mathrm{Hf}}(\mathrm{t})$ и модельный возраст родительских пород циркона;

- содержаний элементов-примесей (редких и рассеянных, в том числе редкоземельных, элементов) в цирконе, что дает возможность прогнозировать тип родительских пород циркона.

Такой интегральный подход приводит к более надежной идентификации пород-источников детритовых цирконов и к реконструкции картины эволюции питающих провинций [Griffin et al., 2004, 2006; Veevers et al., 2005, 2006; Belousova et al., 2006], по сравнению с классическими $\mathrm{U} / \mathrm{Pb}$ возрастами детритовых цирконов.

Пробы дезинтегрированы вручную в чугунной ступке. Измельченный (до 0.3 мм) материал отмучен в проточной водопроводной воде и после просушки разделен в бромоформе. Зерна циркона, содержащиеся в полученных таким образом концентратах тяжелых (>2.89 г/ $\left.\mathrm{cm}^{3}\right)$ минералов, характеризуются разнообразными цветовыми оттенками и размерами (от мельчайших осколков до 300 мкм). Около 130 случайно отобранных (в университете Маквори, Сидней, Австралия) цирконов из пробы К13-206 и более 1000 случайно отобранных (в Стендфордском университете, Калифорния, США) цирконов из пробы M08-16-1 имплантированы в эпоксидные шашки и приполированы на половину толщины зерен. Цирконы из этих шашек были изучены в катодных лучах. Выбор цирконовых зерен и/или их частей, пригодных для изотопных и геохимических анализов, а также сами эти анализы выполнены в центре CCFS/GEMOC (университет Маквори, Сидней, Австралия).

Цирконы из пробы М08-16-1 преимущественно (примерно 90 \%) розовые и темно-розовые до вишневых, прозрачные и полупрозрачные кристаллы с матовой поверхностью. Их размер от 250 мкм и менее. Мелкие (<100 мкм) зерна - удлиненные довольно хорошо окатанные прозрачные кристаллы розового и, реже, желтого цвета. Большинство крупных зерен (>100 мкм) хорошо и весьма хорошо окатаны, имеют овальную или шаровидную форму. Кроме того, встречаются редкие крупные слегка удлиненные полупрозрачные опаловидные зерна с матовой поверхностью, а также - водяно-прозрачные или очень светло-розовые, изометричные слабоокатанные многогранные кристаллы с сильным алмазным блеском на гранях. Специфические группы однотипных цирконов далее для краткости именуются КВП (крупные вишневые прозрачные) и ПЖ (прозрачные желтые). Все цирконы из пробы К13-206 сильно окатаны, преимущественно мелкие (<150 мкм, обычно <100 мкм), чаще всего бесцветные, иногда светло-розовые или светло-желтые.

В обеих пробах нет правильно кристаллографически оформленных неокатанных зерен с четкой катодно-люминесцентной (далее для краткости CL) зональностью, т.е. нет зерен, которые можно было бы трактовать как первично-магматические зерна первого цикла седиментации. Зерна или их части очень различны по CL-светимости (от почти черных до ярко-белых) и также вариабельны по внутренней структуре. Встречаются зерна как с простой или сложной осциляторной структурой (зерна магматического происхождения), так и с почти монотонной светимостью в катодных лучах (метаморфически и/или гидротермально переработанные зерна или их фрагменты). Зерна часто состоят из двух (и более) разноразмерных частей, одна из которых - фрагмент кристалла с хорошей CL-зональностью, а другая - фрагмент кристалла фактически без CL-зональности. Это признаки того, что цирконы участвовали в магматической/метаморфической переработке [Corfu et al., 2003]. Почти все цирконы содержат инородные включения, метамиктные зоны, а местами нарушены трещинами.

Для изотопного датирования отобраны зерна, в которых удалось наметить области (диаметр $>40$ мкм) без явных нарушений и включений. Описание аппаратуры (LA-ICP-MS), а также технология измерений, методические приемы и константы, используемые для обработки первичных аналити- 
ческих данных, приведены в работах [Jackson et al., 2004; Yuan et al., 2008].

\section{4. АНАЛИЗ РЕЗУЛЬТАТОВ ИЗУЧЕНИЯ U/РВ-ИЗОТОПНОЙ СИСТЕМЫ ЦИРКОНОВ}

В существующих технологиях изучение $\mathrm{U} / \mathrm{Pb}$ изотопии циркона позволяет оценивать его возраст одновременно по двум независимым изотопным системам ${ }^{238} \mathrm{U} \rightarrow{ }^{206} \mathrm{~Pb}$ и ${ }^{235} \mathrm{U} \rightarrow{ }^{207} \mathrm{~Pb}$ (радиогенные изотопы свинца ${ }^{206} \mathrm{~Pb}$ и ${ }^{207} \mathrm{~Pb}$ являются конечными продуктами радиоактивного распада ${ }^{238 U}$ и

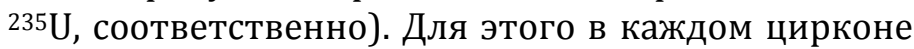
(или его части) измеряются содержания четырех изотопов свинца $\left({ }^{204} \mathrm{~Pb},{ }^{206} \mathrm{~Pb},{ }^{207} \mathrm{~Pb}\right.$ и $\left.{ }^{208} \mathrm{~Pb}\right)$, двух урана $\left(235 \mathrm{U}\right.$ и $\left.{ }^{238} \mathrm{U}\right)$ и одного тория $(232 \mathrm{Th})$. По измеренным отношениям ${ }^{206} \mathrm{~Pb} /{ }^{238} \mathrm{U}$ и ${ }^{207} \mathrm{~Pb} /{ }^{235} \mathrm{U}$ можно получить независимые оценки возраста циркона. Если две возрастные оценки находятся в хорошем согласии (конкордантный возраст циркона), то это свидетельствует о ненарушенности U/Th/Pbизотопной системы циркона и на диаграмме «206 $\mathrm{Pb} /{ }^{238} \mathrm{U} v s{ }^{207} \mathrm{~Pb} /{ }^{235} \mathrm{U} »$ фигуративные точки располагаются на линии, называемой конкордией. Если возрастные оценки сильно различаются, то точки далеко «отскакивают» от этой линии, а значения возраста классифицируются как дискордантные. Результаты каждого анализа характеризуются дискордантностью D - величиной, дающей оценку степени отклонения положения фигуративной точки от конкордии. Дискордантность D вычисляется по формуле:

$$
\begin{aligned}
& \mathrm{D}=100 \% \times \\
& \times\left[\text { возраст }\left(206 \mathrm{~Pb} /{ }^{238} \mathrm{U}\right) / \text { возраст }\left({ }^{207} \mathrm{~Pb} /{ }^{206} \mathrm{~Pb}\right)-1\right] .
\end{aligned}
$$

Обычно датировки, дискордантность которых попадает в интервал значений $10 \%>\mathrm{D}>-10 \%$ (т.е. $|\mathrm{D}|<10 \%)$, используются для дальнейшего рассмотрения и обсуждения, при этом возраст древних (>1 млрд лет) цирконов вычисляется по отношению ${ }^{206} \mathrm{~Pb} /{ }^{207} \mathrm{~Pb}$, а для молодых (<1 млрд лет) - по отношению ${ }^{206} \mathrm{~Pb} /{ }^{238} \mathrm{U}$. Для того чтобы визуализировать характер распределения значений возраста детритовых цирконов в полученных наборах, строятся гистограммы и кривые плотности вероятности (КПВ) возрастов [Ludwig, 2001; Vermeesch, 2012], которые используются для сравнения с таковыми, построенными для датировок цирконов из других проб, а также для сравнения с данными, характеризующими возраст кристаллических комплексов потенциальных областей эрозии. Датировки с $|\mathrm{D}|>10 \%$ не используются ни в гистограммах, ни в $K П В$, ни для интерпретации Lu/Hf-изотопной системы. Однако они могут быть использованы для построения дискордий и других приложений (решения частных специфических задач).

Возраст группы самых молодых цирконов с хорошей аналитической погрешностью и приемлемой дискордантностью иногда удается использовать для ограничения максимального возраста осадочной толщи, из которой была отобрана изученная проба.

По классификации [Andersen, 2005] при числе зерен в группе 0-5 \% от общего количества датированных зерен эта группа классифицируется как примесная (accessory), от 6 до $19 \%$ - как второстепенная (minor), от 20 до $49 \%$ - как значительная (major), от 50 до $79 \%$ - как существенная (large), от 80 до 100 \% - как доминирующая (dominant). Чем больше зерен датировано в пробе, тем выше статистическая значимость результатов. По оценкам [Vermeesch, 2004; Andersen, 2005] наработанный практический опыт и модельные статистические оценки свидетельствуют о том, что для пилотного исследования, которое должно охарактеризовать значительные, существенные и доминирующие группы цирконов, но может пропустить примесные и второстепенные группы, минимальное количество датированных зерен в пробе 35-70 (в зависимости от сложности возрастного распределения). Для фиксации примесных и второстепенных групп с достаточно высокой степенью вероятности (более $90 \%$ ) необходимое количество анализов (датировок) должно быть более 100, рекомендуемая величина - 117 датировок.

\section{5. ИЗУЧЕНИЕ И АНАЛИЗ LU/НF-ИЗОТОПНОЙ СИСТЕМЫ ЦИРКОНОВ}

Главным параметром, характеризующим Lu/Hfизотопную систему циркона, является величина $\varepsilon_{\mathrm{Hf}}(\mathrm{t})$ (далее чаще всего для краткости $-\varepsilon_{\mathrm{Hf}}$ ), которая представляет собой отклонение измеренного в цирконе отношения $\left({ }^{176} \mathrm{Hf} /{ }^{177} \mathrm{Hf}\right)_{\mathrm{Z}}$ в десятитысячных долях к аналогичному отношению в хондрите (валовый состав силикатной Земли) в данный момент времени. Положительные значения $\varepsilon_{\text {нf }}$ свидетельствуют о ювенильном (мантийном) происхождении магмы родительских пород циркона, существенно отрицательные значения $\varepsilon_{\mathrm{Hf}}<<0$ - о том, что в магму было вовлечено изотопно-зрелое вещество континентальной коры [Griffin et al., 2000, 2004, 2006; Belousova et al., 2006, 2010].

При изучении Lu/Hf-изотопной системы циркона измерялись содержания пяти изотопов: ${ }^{176} \mathrm{Hf}$, ${ }^{177} \mathrm{Hf},{ }^{176} \mathrm{Lu},{ }^{177} \mathrm{Lu}$ и ${ }^{176} \mathrm{Yb}$. Величина содержания ${ }^{176} \mathrm{Yb}$ используется для внешнего контроля измерений [Yuan et al., 2008]. Далее расчет $\varepsilon_{\mathrm{Hf}}(\mathrm{t})$ выполнялся по формуле: 
$\varepsilon_{\mathrm{Hf}}(\mathrm{t})=\left\{\left[\left(176 \mathrm{Hf} /{ }^{177} \mathrm{Hf}\right)_{\mathrm{Z}^{-}}\left({ }^{176} \mathrm{Hf} /{ }^{177} \mathrm{Hf}\right)_{\mathrm{Z}^{\times}}\right.\right.$

$\left.\times\left(\mathrm{e}^{\lambda \mathrm{t}}-1\right)\right] /\left[\left({ }^{176} \mathrm{Lu} /{ }^{177} \mathrm{Hf}\right)_{\mathrm{CH}^{-}}\left({ }^{176} \mathrm{Lu} /{ }^{177} \mathrm{Hf}\right)_{\mathrm{CH}} \times\right.$

$\left.\left.\left.\times\left(\mathrm{e}^{\lambda \mathrm{t}}-1\right)\right]-1\right]\right\} \times 10000$,

где $\mathrm{t}$ - возраст кристаллизации циркона, оценен-

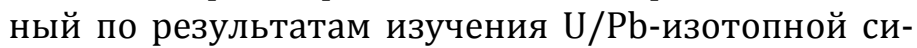
стемы циркона, $\left({ }^{176} \mathrm{Hf} /{ }^{177} \mathrm{Hf}\right)_{\mathrm{z}}$ и $\left({ }^{176} \mathrm{Lu} /{ }^{177} \mathrm{Hf}\right)_{\mathrm{Z}}-$ измеренные величины изотопных отношений в цирконе. Константа полураспада $\lambda$ для ${ }^{176} \mathrm{Lu}$ была принята $\lambda^{176} \mathrm{Lu}=1.867 \times 10^{-11}$ год $^{-1}$ [Scherer et al., 2001]. Coвременные отношения в хондрите $\left({ }^{176} \mathrm{Hf} /{ }^{177} \mathrm{Hf}\right)_{\mathrm{CH}}=$ $=0.282785 \pm 0.000011$ и $\left({ }^{176} \mathrm{Lu} /{ }^{177} \mathrm{Hf}\right)_{\mathrm{CH}}=0.0336 \pm 0.0001$ приняты по [Bouvier et al., 2008], в деплетированной мантии $\left(176 \mathrm{Hf} /{ }^{177} \mathrm{Hf}\right)_{\mathrm{DM}}=0.28325$ и $\left({ }^{176} \mathrm{Lu} /{ }^{177} \mathrm{Hf}\right)_{\mathrm{DM}}=$ 0.0384 - по [Griffin et al., 2000].

Для каждого зерна детритового циркона, исходя из его $\mathrm{U} / \mathrm{Pb}$-изотопного возраста и начального (инициального - initial) значения изотопного отношения $\left(176 \mathrm{Hf} /{ }^{177} \mathrm{Hf}\right)_{\mathrm{Z}}$ initial, может быть рассчитан модельный возраст корового субстрата $\mathrm{T}_{\mathrm{DM}}^{\mathrm{C}}$ в соответствии с линиями изотопной эволюции для средней континентальной коры [Belousova et al., 2010]. Модельный возраст корового субстрата $\mathrm{T}_{\mathrm{DM}}^{\mathrm{C}}$ (минимальная точность оценок $\sim 0.3$ млрд лет) позволяет оценить верхний лимит времени отделения от мантии корового субстрата родительских пород циркона. Оценки модельного возраста $\mathrm{T}_{\mathrm{DM}}^{\mathrm{C}}$, полученные по Lu/Hf-изотопной системе, сопоставимы с оценками модельного возраста по Sm/Ndизотопной системе.

Модельный возраст мантии Т страта $\mathrm{T}_{\mathrm{DM}}^{\mathrm{C}}$ (двухстадийная модель) оценивался по формулам:

$$
\begin{aligned}
& \mathrm{T}_{\mathrm{DM}}=1 / \lambda \times \ln \left\{1+\left[\left(176 \mathrm{Hf} /{ }^{177} \mathrm{Hf}\right)_{\mathrm{Z}}-\right.\right. \\
& \left.\left.-\left(176 \mathrm{Hf} /{ }^{177} \mathrm{Hf}\right)_{\mathrm{DM}}\right] /\left[\left({ }^{176} \mathrm{Lu} /{ }^{177} \mathrm{Hf}\right)_{\mathrm{Z}}-\left(176 \mathrm{Lu} /{ }^{177} \mathrm{Hf}\right)_{\mathrm{DM}}\right]\right\} \\
& \mathrm{T}_{\mathrm{DM}}^{\mathrm{C}}=\mathrm{T}_{\mathrm{DM}}-\left[\mathrm{T}_{\mathrm{DM}}-\mathrm{t}\right] \times\left[\left(\mathrm{F}_{\mathrm{C}}-\mathrm{F}_{\mathrm{Z}}\right) /\left(\mathrm{F}_{\mathrm{C}}-\mathrm{F}_{\mathrm{DM}}\right)\right] .
\end{aligned}
$$

Параметр $\mathrm{F}$ для средней коры (C), изученного циркона (Z) и деплетированной мантии (DM) вычислялся по формуле:

$$
\mathrm{F}_{\mathrm{C}, \mathrm{Z}, \mathrm{DM}}=\left\{\left[\left({ }^{176} \mathrm{Lu} /{ }^{177} \mathrm{Hf}\right)_{\mathrm{C}, \mathrm{Z}, \mathrm{DM}}\right] /\left[\left({ }^{176} \mathrm{Lu} /{ }^{177} \mathrm{Hf}\right)_{\mathrm{CH}}\right]-1\right\} \text {. }
$$

Значение ${ }^{176} \mathrm{Lu} /{ }^{177} \mathrm{Hf}$ для средней коры принималось равным 0.015, более подробно обоснование схемы расчетов изложено в работе [Liu et al., 2013].

Результаты расчетов представляются в виде диаграммы « $\varepsilon_{\mathrm{Hf}}(\mathrm{t})$ vs $\mathrm{U} / \mathrm{Pb}$-изотопный возраст циркона» (далее - «Диаграмма $\left.\varepsilon_{\mathrm{Hf}} »\right)$. На «Диаграмму $\varepsilon_{\mathrm{Hf}}$ » также наносится линия, характеризующая хондритовый резервуар (Chondritic Unfractionated Reservoir - CHUR) $\left.-\varepsilon_{\mathrm{Hf}}(\mathrm{t})=0\right)$, линия эволюции деплетированной мантии (DM) и реперные линии эволюции средней континентальной коры (возраст - 0.5, 1.0, 1.5, 2.0... млрд лет).

\section{6. АНАЛИЗ СОДЕРЖАНИЯ ЭЛЕМЕНТОВ-ПРИМЕСЕЙ В ЦИРКОНАХ}

Попытки определения характеристик отдельных зерен циркона (установление магматической или метаморфической/гидротермальной природы кристалла (или даже отдельно ядра/оболочки), прогноз типа родительских пород циркона, оценка температуры кристаллизации и др. по морфологическим особенностям кристалла и метамиктных зон в нем, оптическим, CL- и BSE-имиджам, содержаниям в цирконе элементов-примесей, составу газо-флюидных и инхеритных включений и другим данным) имеют очень длительную историю [Harrison, Watson, 1983; Vavra, 1990; Hinton, Upton, 1991; Halden et al., 1993; Watson, 1996; Hoskin, Ireland, 2000; Griffin et al., 2000, 2004; Poller et al., 2001; Fedo et al., 2003; Corfu et al., 2003; Hoskin, Schaltegger, 2003; Watson et al., 2006; Claiborne et al., 2006; Belousova et al., 2002, 2006, 2010; Grimes et al., 2007; Aranovich et al., 2017; и мн. др.]. Но в отличие от U/Pb датирования и изучения Hf-изотопии цирконов, где уже сложились хорошо работающие признанные в мировом сообществе технологии, в этом направлении изучения цирконов пока такой общепринятой технологии еще не выработано.

Однако к настоящему времени уже вполне надежно установлено, что для цирконов из некоторых типов пород фиксируются определенные статистические тенденции и заметные отличия в концентрациях элементов-примесей [Fedotova et al., 2008; Kostitsyn et al., 2015; Fershtater et al., 2012; Belousova et al., 2002, 2015; Grimes et al., 2015; Kaczmarek et al., 2008; Kirkland et al., 2015; и мн. др.]. Так, в целом, концентрации РЗЭ в цирконах увеличиваются от основных пород - базитов (габброидов и базальтоидов), где суммарные содержания РЗЭ высокие - сотни и первые тысячи г/т, к кремнекислым (к гранитоидам и их эффузивным аналогам), где суммарные содержания РЗЭ уже 5-15 тысяч г/т, а в цирконах из пегматитов могут достигать нескольких процентов (десятки тысяч г/т). Для таких пород, как кимберлиты, типичное суммарное содержание РЗЭ в цирконах обычно меньше 50 г/т. В цирконах из карбонатитов и лампроитов этот параметр может возрасти до 500 г/т [Belousova et al., 2002], но в среднем составляет 10-250 г/т [Hoskin, Ireland, 2000]. Нельзя при этом не отметить, что у циркона, кристаллизовавшегося в присутствии граната, могут также быть пониженные содержания тяжелых РЗЭ и Y, так как гранат конкурирует с цирконом по этим элементам. Однако такие случаи описаны пока только для цирконов высокотемпературного метаморфического происхождения [Rubatto, 2002; Rubatto, Hermann, 2007; Fedotova et al., 2008; Fornelli et al., 2014]. 
Важным индикатором является отношение Th/U (см. обзор [Kirkland et al., 2015]), которое в большинстве цирконов варьируется от 0.1 до 1.0. Низкие отношения $\mathrm{Th} / \mathrm{U}$ считаются статистически свойственными кристаллам циркона метаморфического происхождения, в отличие от цирконов магматического происхождения. Однако по величине «порогового» значения Th/U до сих пор нет консенсуса: в разных работах предлагаются величины от 0.5 до 0.1: в [Kirkland et al., 2015] - 0.5, в [Hoskin, Schaltegger, 2003] - 0.2, в [Teipel et al., 2004] 0.1 . Высокие отношения Th/U>1.5 вместе с другими характеристиками статистически присущи цирконам из мафических пород [Kaczmarek et al., 2008; Linnemann et al., 2011]. Нельзя при этом не отметить, что цирконы с высокими значениями $\mathrm{Th} / \mathrm{U}$ иногда формируются в обстановках высоких степеней метаморфизма [Wanless et al., 2011]. Для цирконов, кристаллизовавшихся в гранитах при низких температурах, характерны более высокие содержания U и пониженные Th, что в результате приводит и к пониженным величинам Th/U в низкотемпературных кристаллах [Harrison et al., 2007].

Очень низкие отношения U/Yb $(<0.1)$ фиксируются для цирконов из океанических базальтов. Более высокие величины не уникальны и могут быть присущи широкому спектру пород. Однако в целом увеличение отношения $\mathrm{U} / \mathrm{Yb}$, а также $\mathrm{Nb} / \mathrm{Yb}$ и содержаний Hf в цирконах свидетельствует о фракционировании их родительских магм и/или коровом загрязнении и отражает тенденции изменения состава магм в направлении от примитивного в сторону более обогащенного корового. Наиболее статистически действенными для отделения цирконов из океанических базальтов и цирконов континентального генезиса являются диаграммы «U/Yb vs $\mathrm{Hf} »$ и «U/Yb vs $\mathrm{Nb} / \mathrm{Yb} »[$ Grimes et al., 2015].

Важную информацию о цирконах несут нормированные спектры РЗЭ (мы используем значения для CI-хондрита по работе [McDonough, Sun, 1995], в г/т: $\mathrm{La}=0.237 ; \mathrm{Ce}=0.613 ; \mathrm{Pr}=0.0928 ; \mathrm{Nd}=0.457 ; \mathrm{Sm}=0.148$; $\mathrm{Eu}=0.0563 ; \mathrm{Gd}=0.199 ; \mathrm{Tb}=0.0361 ; \mathrm{Dy}=0.246 ; \mathrm{Ho}=$ $=0.0546 ; \mathrm{Er}=0.16 ; \mathrm{Yb}=0.161 ; \mathrm{Lu}=0.0246)$. Типичным для спектров РЗЭ цирконов является монотонное увеличение содержаний элементов от легких к тяжелым, которое осложнено двумя аномалиями: положительной Се и отрицательной Еu. Величины аномалий характеризуются отношением измеренного значения Се или Еu в цирконе, нормированного к хондриту (Се сІ или $\mathrm{Eu}_{\mathrm{CI}}$ ) к прогнозируемому как среднее геометрическое по содержаниям соседних

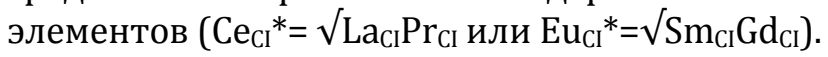

Спектры РЗЭ цирконов из гранитоидов весьма упорядочены в области тяжелых РЗЭ: в интервале от Dy до Lu наклон спайдер-диаграмм цирконов довольно устойчив, его величину характеризуют отношением $\mathrm{Yb} / \mathrm{Sm}$ (или Lu/Gd). Статистически циркон, который кристаллизовался в изверженной породе, имеет более крутой наклон для тяжелых PЗЭ (бо́льшие величины $\mathrm{Yb} / \mathrm{Sm}$ ), чем кристалл, образовавшийся в породах высоких степеней метаморфизма [Rubatto, 2002; Fedotova et al., 2008].

К настоящему времени уже накоплены большие объемы данных по содержанию элементов-примесей в цирконах магматического происхождения из магматических пород разных вещественных типов. На основе статистической обработки этих данных предприняты удачные попытки решения обратной задачи - по характеру распределения в цирконах элементов-примесей с достаточно высокой степенью вероятности прогнозировать некоторые специфические вещественные типы магматических пород, родительских по отношению к изученным цирконам. В частности, на этой основе разработан алгоритм CART, принцип работы которого - это многошаговая классификационная процедура в виде разветвляющегося бинарного «дерева»[Belousova et al., 2002]. На каждом шаге в точке ветвления классификационного «дерева» для определения дальнейшего пути продвижения по «дереву» используются полученные для циркона значения содержаний элементов-примесей. Каждая конечная ветвь «дерева» соответствует определенному типу пород (кимберлитам, базитам, нефелиновым сиенитам, карбонатитам и др.). Таким образом, на основе анализа данных о содержании в цирконе элементов-примесей прогнозируется вещественный тип родительских пород циркона.

Основная цель использования алгоритма CART первичное отделение магматогенных цирконов, родительскими породами для которых могли быть специфические редко встречающиеся породные комплексы, от цирконов из гранитоидов и их эффузивных вещественных аналогов, которые являются основными источниками цирконов. Последние в результате классификации подразделяются по кремнекислотности (т.е. по процентному содержанию $\mathrm{SiO}_{2}$ в породе) на три группы - породы с пониженной $\left(\mathrm{SiO}_{2}<65 \%\right)$, нормальной $\left(\mathrm{SiO}_{2}=65-75 \%\right)$ и повышенной $\left(\mathrm{SiO}_{2}>75 \%\right.$ кремнекислотностью. Далее для краткости эти группы называются «диориты», «граниты» и «лейкограниты», а соответствующие цирконы - «диоритные», «гранитные», «лейкогранитные» и т.п. Классификационным признаком разделения наиболее часто встречающихся цирконов из «гранитов» и «диоритов» является содержание $\mathrm{Yb}=501$ г/т.

Поскольку прогноз типа родительских пород носит статистический характер, прогноз для индивидуального циркона пока не очень надежен. В связи с этим содержательно интерпретируются только валовые параметры кремнекислотности для боль- 
T.V. Romanyuk et al.: Paleotectonic and paleogeographic conditions for the accumulation of the Lower Riphean Ai Formation...

ших групп цирконов («граниты»и «диориты») и статистически представительные группы специфических цирконов, родственность происхождения которых по особенностям содержания элементовпримесей подтверждается также сходством U-Pb значений возраста или Hf-изотопией.

\section{7. АНАЛИТИЧЕСКИЕ РЕЗУЛЬТАТЫ ИЗУЧЕНИЯ ДЕТРИТОВЫХ ЦИРКОНОВ МЕТОДОМ «ТЕRRANEСНRONЕ®» ИЗ ЧУДИНСКОЙ (ПРОБА К13-206) И НАВЫШСКОЙ (ПРОБА М08-16-1) ПОДСВИТ НИЖНЕРИФЕЙСКОЙ Айской свитЫ}

Для цирконов из пробы К13-206 на первом этапе проведено одновременное изучение $\mathrm{U} / \mathrm{Pb}$-изотопной системы и определение содержаний в них элементов-примесей, а на втором - изучение Lu/Hfизотопной системы этих же зерен цирконов.

Для цирконов из пробы М08-16-1 сначала проведено изучение $\mathrm{U} / \mathrm{Pb}$-изотопной системы (в том числе для двух морфологических типов цирконов: 7 из группы ПЖ и 9 из группы КВП), а затем проведено выборочное доизучение содержаний элементов-примесей и Lu/Hf-изотопной системы в зернах всех возрастных групп (в том числе 5 из группы ПЖ и 6 из группы КВП).

Измерения параметров U/Pb-изотопной системы в цирконах проводились с использованием цирконовых стандартов Ред-ДжиДжей (Red JG) для калибровки, а Мад-Танк (Mud Tank) и 91500 как измеряемых цирконов для контроля. Во время измерений были получены средние значения возраста Мад-Танк $=741 \pm 5,91500=1060 \pm 5$ и Ред-ДжиДжей= $=626 \pm 15$ млн лет, что согласуется с возрастом этих стандартов [Jackson et al., 2004; Liu et al., 2013].

Измерение содержания элементов-примесей в детритовых цирконах выполнялось для 22 элементов, внешний контроль проводился с использованием стандарта NIST.

Измерения Lu/Hf-изотопной системы контролировались по цирконовым стандартам Мад-Танк и Темора II (Temora II). Во время измерений среднее

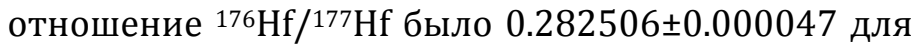
Мад-Танк и $0.282715 \pm 0.000015$ для Темора II, что находится в согласии со значениями для цирконовых стандартов [Jackson et al., 2004; Liu et al., 2013].

Проба К13-206 (чудинская подсвита). Изучение $\mathrm{U} / \mathrm{Pb}$ изотопной системы цирконов и определение содержания элементов-примесей в них было выполнено для 71 зерна. Во многих цирконах просматривались области, которые можно трактовать как фрагменты ядер и оболочек. Однако либо маленький размер областей, либо наличие нарушений не позволили уместить два кратера в одном зерне, чтобы попытаться получить возраст ядер и оболочек в одном цирконе. Изучалась только бо́льшая по размеру область. Циркон № 77 представлял собой игольчатый осколок магматического кристалла с видимой CL-зональностью с шириной $\sim 20$ мкм и очень толстую метаморфическую оболочку без CL-зональности; была изучена только метаморфическая оболочка.

Сильно дискордантные (+10 \%>D>-10 \%) значения $\mathrm{U} / \mathrm{Pb}$-изотопного возраста получены для 11 зерен (рис. 2), остальные 60 значений использованы для построения гистограммы и КПВ (рис. $3, a$ ). Максимальный возраст $2699 \pm 18$ млн лет $(\mathrm{D}=0.37 \%)$ показал циркон № 17, минимальный возраст $1793 \pm 87$ млн лет (D=3.15 \%) - циркон № 79. На КПВ фиксируется единственный доминирующий пик 2055 млн лет. В архейском возрастном диапазоне зафиксированы единичные цирконы и только второстепенное пиковое значение 2705 млн лет подкреплено двумя датировками.

При измерении содержаний элементов-примесей кондиционные результаты получены для всех зерен (рис. 4-12). Для зерна № 20 содержания $\mathrm{Pr}$, a для зерен № 40, 71 и 121 - содержания La оказались ниже предела обнаружения 1 . Цирконы № 79, 112 и 38 высокотитанистые (содержания Ті выше, чем в хондрите). Цирконы № 79 и 95 показали повышенные содержания фосфора - вероятно, в абляционный кратер попали небольшие включения апатита. В зерне № 79, показавшем большую аналитическую погрешность при определении $\mathrm{U} / \mathrm{Pb}$ возраста, также зафиксировано сильное обогащение легкими РЗЭ.

Для 63 зерен, размер которых допускал второй кратер размером 40 мкм и оценки $\mathrm{U} / \mathrm{Pb}$ возраста показали приемлемую дискордантность, была изучена Lu/Hf-изотопная система. Для бо́льшей части цирконов получены положительные значения величин $\varepsilon_{\text {Hf }}$ с максимальным значением $+10.4 \pm 2.5$ (№ 88). Среди отрицательных значений минимальное $-12.5 \pm 0.4$ (№ 79). Оценки модельного возраста корового субстрата $\mathrm{T}_{\mathrm{DM}}^{\mathrm{C}}$ - распределены в диапазоне 1.99 - 3.27 млрд лет (рис. 13, a).

Проба М08-16-1 (навышская подсвита). Изучение $\mathrm{U} / \mathrm{Pb}$-изотопной системы выполнено для 89 цирконов. Для 13 из них датированы и центральные, и краевые части. Всего, таким образом, было получено 102 набора изотопных данных. Из них 89 анализов характеризуются приемлемой степенью дискордантности и охватывают диапазон от $3625 \pm 53$

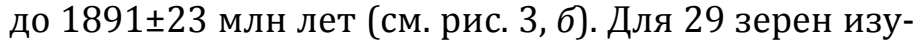
чено содержание элементов-примесей, все анализы кондиционные (см. рис. 4-12).

\footnotetext{
${ }^{1}$ В дальнейшем при расчете величин Се-аномалий содержания La для этих цирконов принимались равными 0.01 г/т.
} 


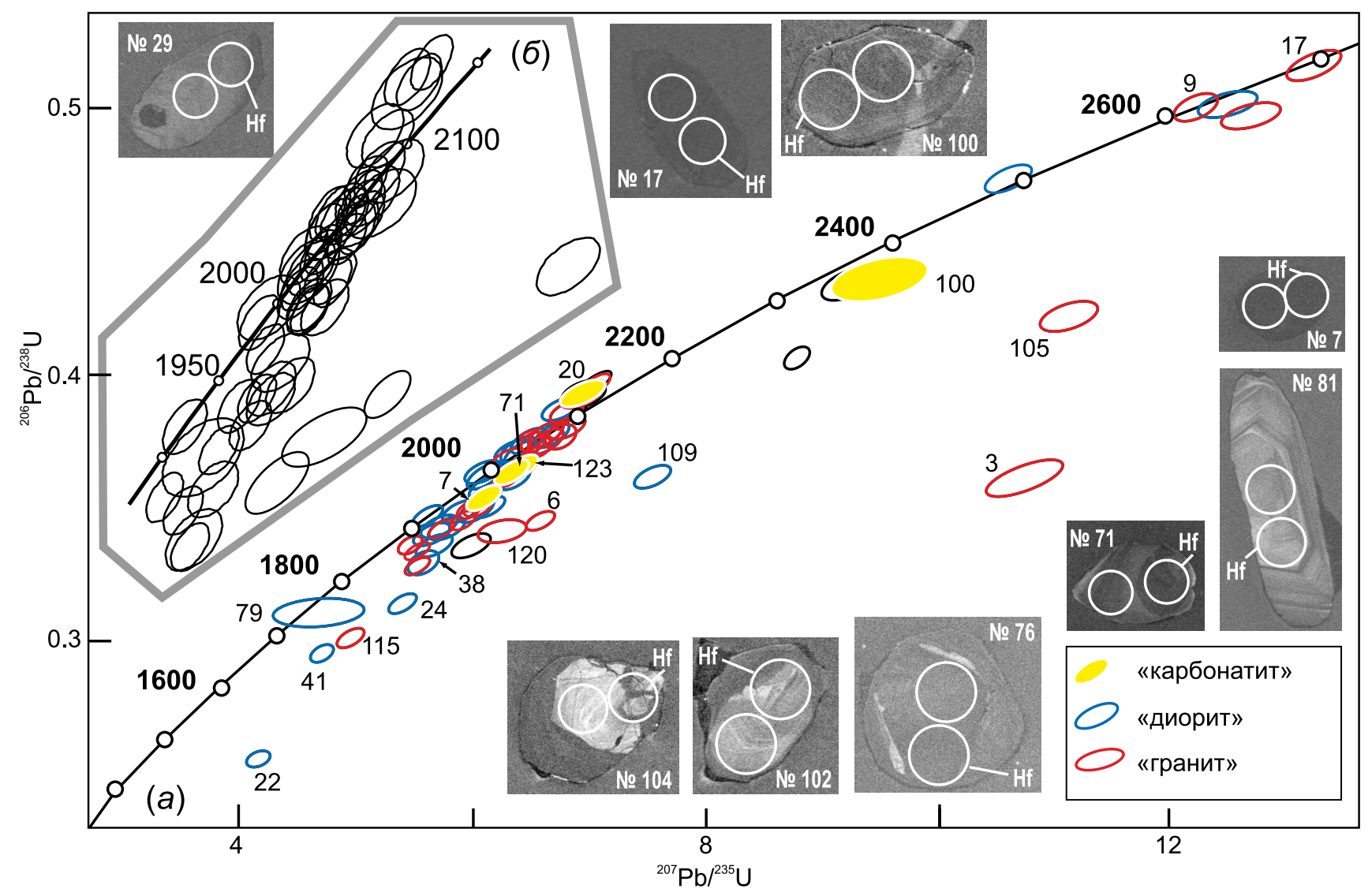

Рис. 2. Результаты изучения U/Th/Pb-изотопной системы детритовых цирконов из пробы К13-206. (a) - конкордия и эллипсы (некоторые с номерами анализов), показывающие 95\%-ный доверительный интервал измерений для всех анализов; (б) - увеличенный фрагмент конкордии. На этом и некоторых следующих рисунках в виде врезок показаны CL-имиджи некоторых цирконов, диаметр кратеров абляции - 40 мкм.

Fig. 2. The U/Th/Pb-isotope system of detrital zircons (sample K13-206): the study results. (a) - concordia and ellipses (several assays numbers are given) showing $95 \%$ confidence interval of the measurements for all the assays; (б) - zoomedin concordia fragment. In this and some of the following figures, the insets show CL-images of some zircons; the diameter of ablation craters is $40 \mu \mathrm{m}$.

Для 41 зерна, оценки $\mathrm{U} / \mathrm{Pb}$ возраста которых показали приемлемую дискордантность, доизучена $\mathrm{Lu} / \mathrm{Hf}-$ изотопная система (рис. 13, б) и получены величины $\varepsilon_{\text {Hf }}$ от $+7.1 \pm 0.6$ до $-20.2 \pm 0.5$. Рассчитанный модельный возраст корового субстрата $\left(\mathrm{T}_{\mathrm{DM}}^{\mathrm{C}}\right)$ показал значения от 2.25 до 3.95 млрд лет.

\section{8. ОБСУЖДЕНИЕ И ИНТЕРПРЕТАЦИЯ ПОЛУЧЕННЫХ АНАЛИТИЧЕСКИХ ДАННЫХ}

Самый молодой из исследованных в пробе M08-16-1 цирконов показал U/Pb-изотопный возраст $1891 \pm 23$ млн лет. Это означает, что в настоящее время возраст навышской подсвиты ограничен геохронологическими датировками между $1752 \pm 18$ млн лет $(\mathrm{U} / \mathrm{Pb}$-изотопный возраст цирконов из трахибазальтов [Krasnobaev et al., 2013], залегающих выше по разрезу айской свиты) и $1891 \pm 23$ млн лет (возраст самого молодого детритового циркона в песчаниках этой подсвиты).

Для пробы К13-206 минимальный возраст $1793 \pm 87$ млн лет получен для циркона № 79, для которого при приемлемой дискордантности $(\mathrm{D}=3.15 \%)$ получена большая аналитическая погрешность. Хотя CL-изображение циркона без видимых нарушений (см. рис. 4), некоторые особенности содержаний элементов-примесей (повышенное содержание фосфора, титана и легких РЗЭ) свидетельствуют о том, что циркон, скорее всего, метамиктный с нарушенной U/Pb-изотопной системой и возможной потерей свинца. Все это ставит под сомнение надежность возраста этого зерна и препятствует его использованию для ограничения возраста изученной толщи. Следующее по возрасту (в сторону удревнения) значение $1921 \pm 25$ млн лет (№ 29, $D=0.37 \%$ ) - не противоречит стратиграфическому возрасту чудинской 

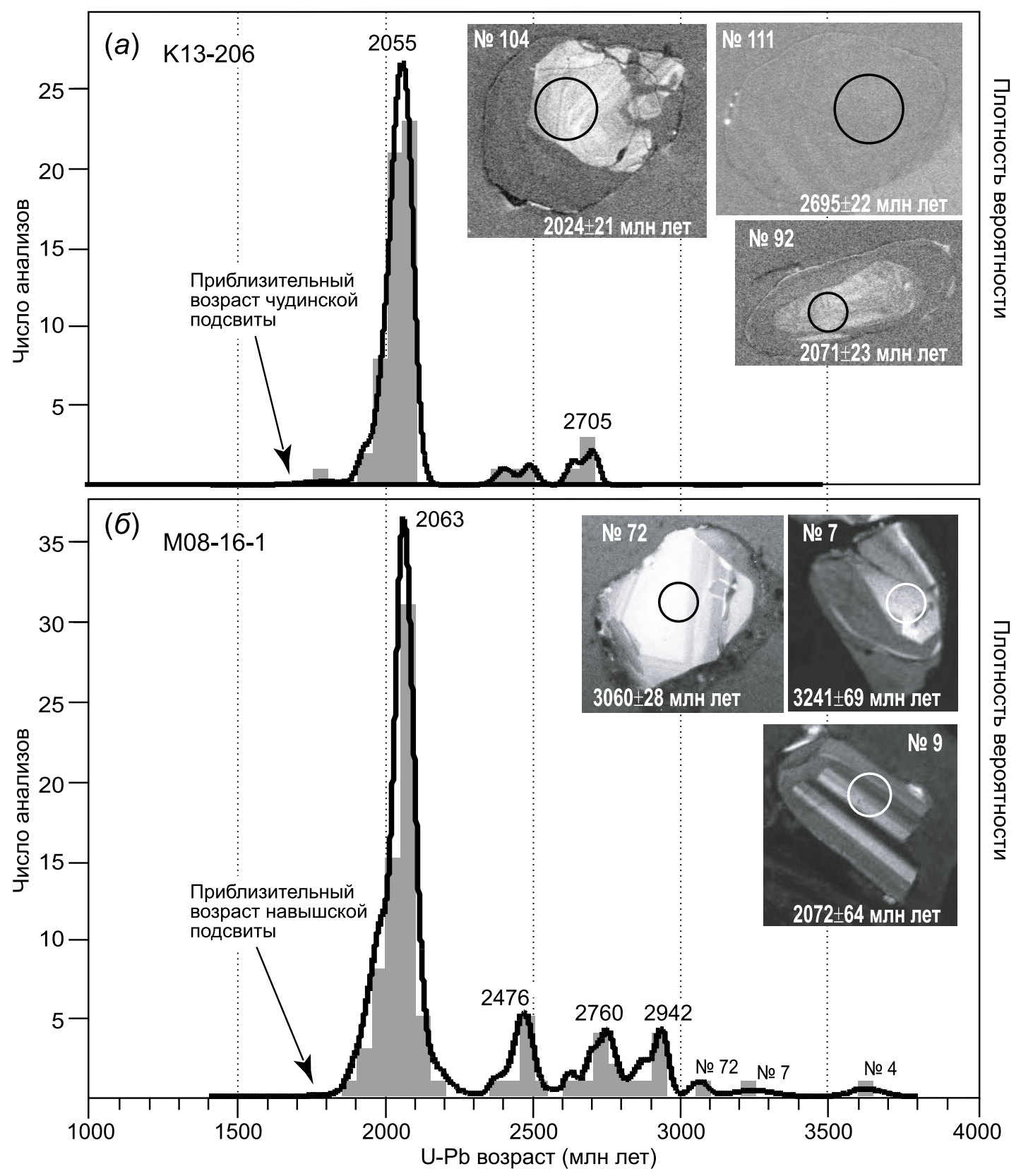

Рис. 3. Гистограмма и кривая плотности вероятности U/Pb значений возраста детритовых цирконов с дискордантностью $-10 \% \leq \mathrm{D} \leq+10 \%$ для проб К13-206 (а) и М08-16-1 (б).

Fig. 3. The histogram and the probability density curve of the detrital zircon $U / P b$ ages. Discordance $-10 \% \leq D \leq+10 \%$ for samples K13-206 (a) and M08-16-1 (б).

подсвиты айской свиты, но и не может его уточнить.

Сопоставление возрастных характеристик цирконов из проб К13-206 и М08-16-1 (см. рис. 3) показывает, в целом, их схожесть: в обеих пробах преобладают палеопротерозойские цирконы, при этом доминирующие пики фактически совпали - 2063 и 2055 млн лет. Архей представлен немногочисленными зернами, но в пробе М08-16-1 он все же более представителен, и, в частности, присутствуют три очень древних циркона с возрастом древнее 3 млрд лет - 3060 28 (№ 72), $3241 \pm 69$ (№ 7) и $3625 \pm 53$ (№ 4) млн лет. Однако комплексные изотопногеохимические различия цирконов из изученных проб весьма существенные (рис. 13). Прежде всего, параметры Lu/Hf-изотопной системы архейских цирконов в пробах М08-16-1 и К13-206 кардинально различаются. Для пробы К13-206 $\varepsilon_{\mathrm{Hf}}$ цирконов положительные, что не оставляет сомнений в ювенильном происхождении субстрата их родительских пород. В пробе М08-16-1 - представлены как ювенильные цирконы, так и цирконы с 


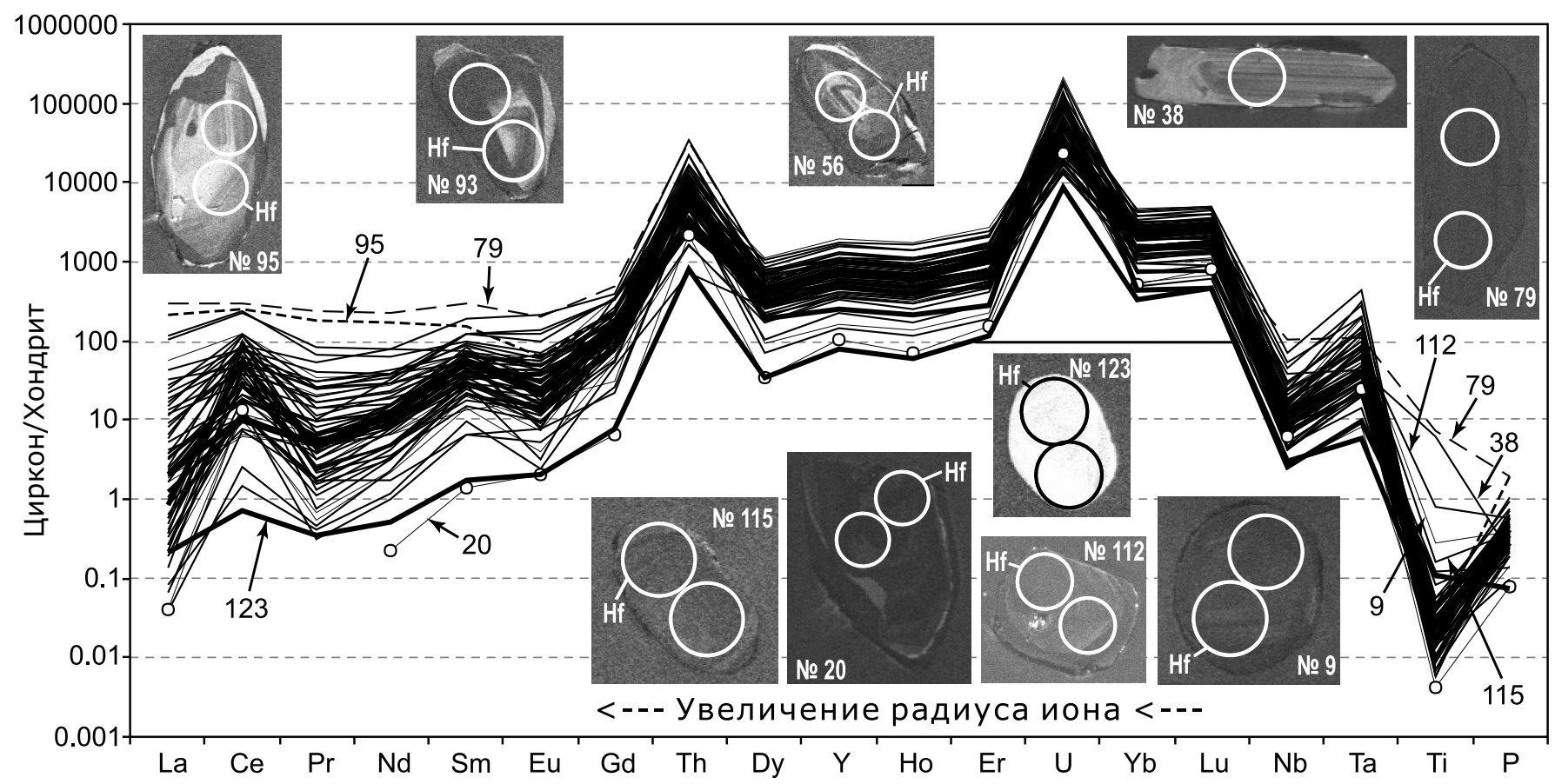

Рис. 4. Хондрито-нормализованные (CI-хондрит по [McDonough, Sun, 1995]) содержания элементов-примесей в детритовых цирконах из пробы К13-206.

Fig. 4. Chondrite-normalized contents (CI-chondrite after [McDonough, Sun, 1995]) of trace elements in the detrital zircons (sample K13-206).

примесью древнего материала континентальной коры.

В пяти цирконах из пробы М08-16-1 (см. рис. 11, б) отношение Th/U>1.5, что может свидетельствовать о их происхождении из мафических пород. Однако ни во внешнем виде этих цирконов, ни по другим характеристикам не удалось выявить какой-либо дополнительной схожести их между собой, поэтому мы не выделяем эти цирконы в отдельную группу и этот факт не интерпретируем.

Только в одном случае - циркон № 77 из пробы К13-206, в котором была изучена оболочка, - отношение Th/U существенно ниже 0.1 (см. рис. 11, a), что подтверждает метаморфическую природу оболочки. Хотя во многих случаях изученные части цирконов также имели метаморфический облик (не видно CL зональности), для всех остальных анализов Th/U>0.1, что подразумевает магматическое происхождение изученных частей цирконов, поэтому для первичной оценки типа родительских пород цирконов была использована классификация CART2000 [Belousova et al., 2002]. Для цирконов из пробы К13-206 выявлено (см. рис. 5), что большинство цирконов, наиболее вероятно, имели своими родительскими породами гранитоиды, причем более половины (37 зерен, или 52 \%) - это цирконы из «диоритов», а остальные (32 зерна, или 45 \%) - из «гранитов». Для двух зерен (№ 100 и № 123) прогнозный тип родительских пород - «карбонатиты». Для пробы М08-16-1 аналогичная классификация, показала, что среди родительских пород цирконов доминировали (22 зерна, или 81 \% всех исследованных цирконов из этой пробы) «диориты», второстепенную роль играли «карбонатиты» (5 зерен, или 19 \%, при этом для зерна № 82 как «карбонатитовые» классифицированы и ядро, и оболочка). Таким образом, цирконы из проб К13-206 и М08-16-1 существенно отличаются: в пробе М08-16-1 не зафиксировано ни одного циркона, гранитоидными родительскими породами для которых были «граниты», прогнозируются только «диориты» и «карбонатиты», в то время как в пробе К13-206 почти для половины цирконов родительскими породами были «граниты».

В обеих пробах, помимо наиболее типичных родительских пород цирконов - «гранитов» и «диоритов», классификация CART2000 спрогнозировала зерна, происходящие из «карбонатитов». Именно выявление немногочисленных, иногда единичных цирконов, произошедших из специфических родительских пород, является наиболее интересным и важным результатом для идентификации источников сноса. Но, в отличие от цирконов из «гранитоидов», которые формируют большие группы («граниты» или «диориты»), определяются и интерпретируются статистически, идентификация специфи- 


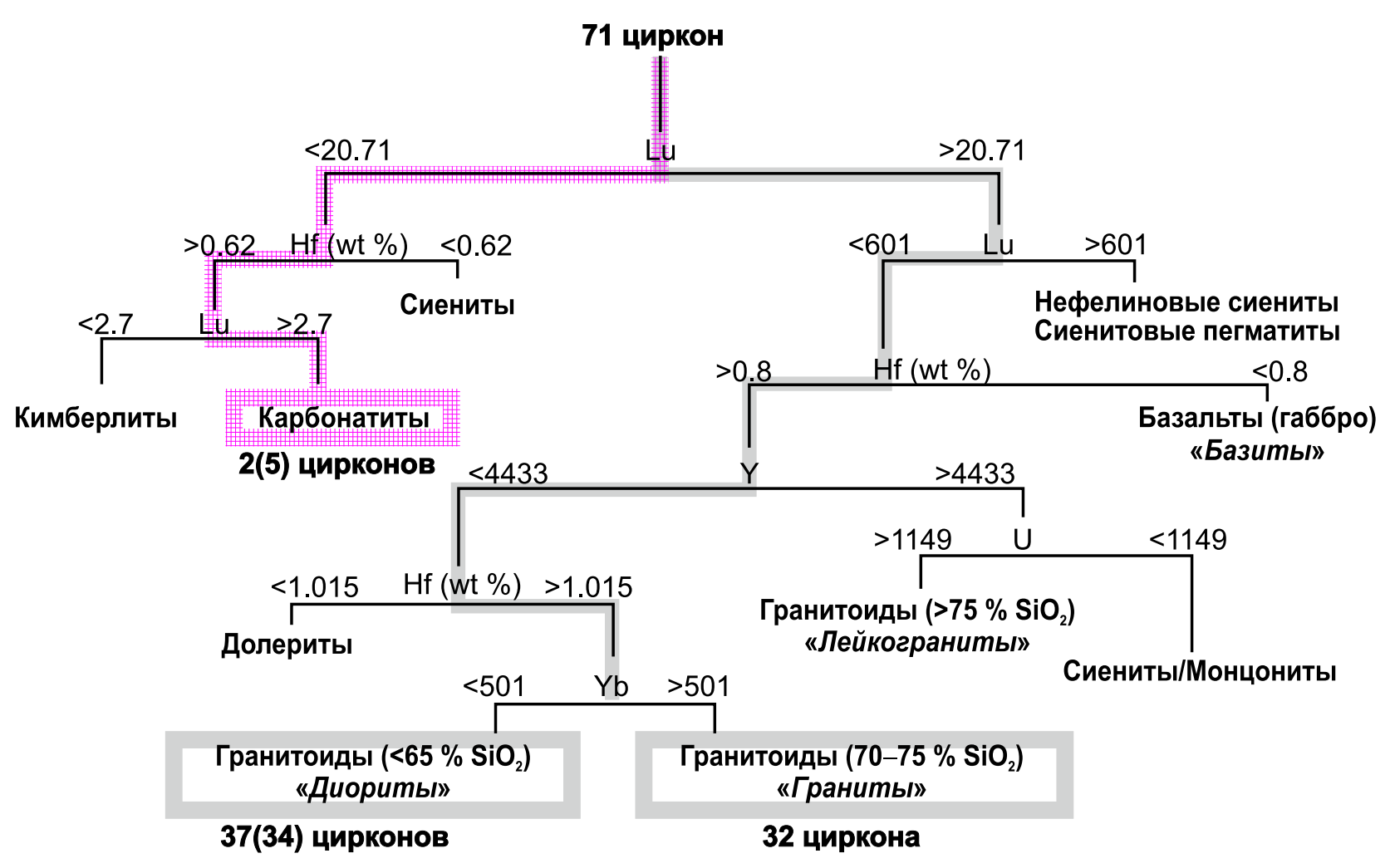

Рис. 5. Классификационное дерево алгоритма CART2000 (по [Belousova et al., 2002]), использованное для первичного статистического прогнозирования типа родительских пород изученных цирконов из пробы К13-206. Серая линия показывает путь по дереву, в соответствии с которым тип родительских пород для подавляющего числа цирконов был классифицирован как «диориты» или «граниты». Красная штриховая линия соответствует пути по дереву для двух цирконов, родительские породы которых были классифицированы как «карбонатиты». В скобках приведено число цирконов по окончательной классификации после «ручной» проверки, характеристики всех «карбонатитовых» цирконов приведены в таблице.

Fig. 5. The CART2000 classification tree (after [Belousova et al., 2002]) used for the initial statistical prediction of the types of mother rocks of zircons (sample K13-206). The grey line shows the path along the tree for distinguishing between the types of mother rocks ("diorites" / "granites") for the major number of zircons. The red dashed line shows the path for the two zircons whose parent rocks are classified as "carbonatites". In brackets, the number of zircons is given according to the final classification after "manual" screening. The characteristics of all "carbonite" zircons are given in Table.

ческих цирконов требует дополнительной «ручной» проверки и доводки, прежде всего - проверки случаев попадания измеренных концентраций в пограничные значения или аномальных «выбросов» для концентраций элементов, по которым работает алгоритм CART2000, визуальной проверки спектров РЗЭ и др.

Для отделения магматических цирконов из кимберлитов/карбонатитов/сиенитов от цирконов из других типов родительских пород наиболее статистически действенным/эффективным критерием является содержание Lu в цирконе ниже порогового значения 20.71 г/т (см. рис. 5). Пониженные содержания РЗЭ вместе с умеренными концентрациями Hf (>0.62 \%) и 2.7 г/т < Lu < 20.71 г/т в классификации CART2000 являются типоморфными («фирменными») признаками цирконов из «карбонатитов». При низких концентрациях Lu обычно и концентра- ции остальных РЗЭ (и суммы РЗЭ) в этом цирконе оказываются пониженными. И действительно, суммарные содержания РЗЭ (см. рис. 6) для всех цирконов, классифицированных как «карбонатитовые», оказываются невысокими (менее 300 г/т), за исключением циркона № 100 (360 г/т) из пробы К13206 и циркона № 24 (465 г/т) из пробы М08-16-1. Спектры РЗЭ (см. рис. 7) для этих цирконов показывают слегка повышенные значения в средней (от Sm до Но) и легкой части спектра РЗЭ, а также очень пологие наклоны спектров в области тяжелых РЗЭ. Это вместе с повышенными значениями суммы РЗЭ и содержаний Y понижает надежность классификации этих цирконов как происходящих из «карбонатитов». Возможно, что они являются продуктом высокотемпературного метаморфизма в присутствии граната. С другой стороны, еще три зерна (№ 7, 20 и 123) из пробы К13-206 и шесть зерен (№ 4, 17, 21, 


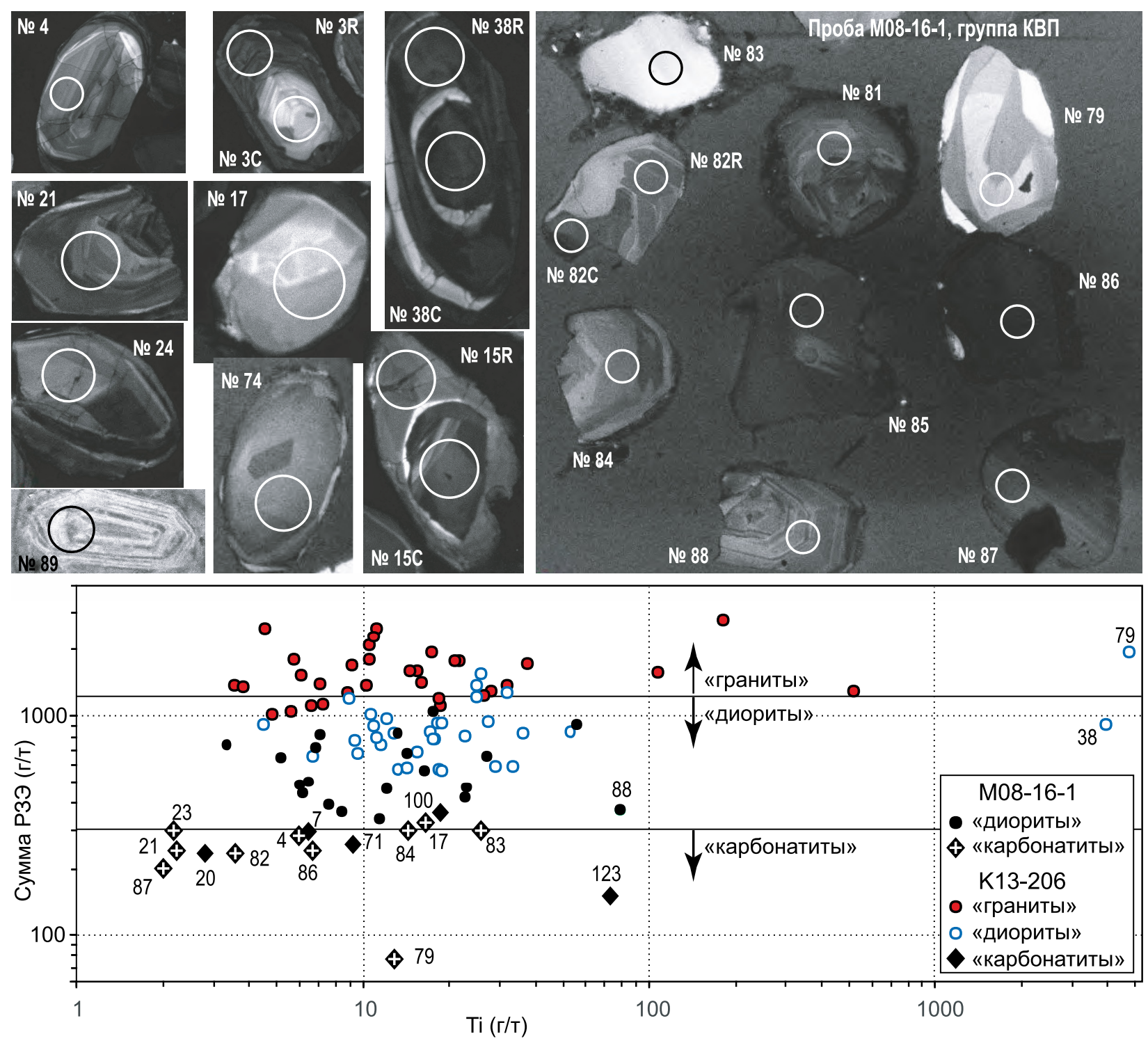

Рис. 6. Диаграмма «Сумма РЗЭ vs Ті» в детритовых цирконах из проб K13-206 и M08-16-1. Cверху - CL-имиджи некоторых цирконов из пробы М08-16-1, справа - из группы КВП (крупные вишневые прозрачные), № 89 - опаловый серый, № 74 - из группы ПЖ (прозрачные желтые).

Fig. 6. REE sum vs Ti diagram for the detrital zircons from samples K13-206 and M08-16-1. Top - CL-images of some zircons from sample M08-16-1; right - large-size transparent cherry-colour zircons, No. 89 - opal-gray zircons, No. 74 - transparent yellow zircons.

23, 83 и 84) из пробы М08-16-1 показали концентрации Lu лишь немного выше порогового значения, но пониженные содержания всех РЗЭ, что позволяет классифицировать их как «карбонатитовые» (таблица). Таким образом, все шесть изученных цирконов группы КВП классифицировались как «карбонатиты». «Карбонатитовые» цирконы также уверенно отделяются от «диоритовых» и «гранитных» по низким содержаниям Y (см. рис. 10), а также Та и $\mathrm{Nb}$ (см. рис. 12), хотя содержания этих элементов в цирконах не использовались при классификации.

«Карбонатитовые» цирконы в обеих пробах демонстрируют совершенно различные изотопно-гео- химические тенденции. В «карбонатитовых» цирконах из пробы К13-206 очень слабо проявлена Се-аномалия (первые единицы, за исключением № 20, где $\left.\mathrm{Ce} / \mathrm{Ce}^{*}=40\right)$, в то время как в пробе M08-16-1 - величины аномалий от более 10 до 100, за исключением № 17 и 24 (см. рис. 11).

В пробе К13-206 четыре циркона из пяти (за исключением № 100) - это внешне не похожие цирконы (у № 123 CL-изображение очень яркое, а у № 20 темное; в № 7 и 71 фиксируется CL-зональность, а у остальных нет), но с близким возрастом (совпадающим в пределах ошибки) и положительными или

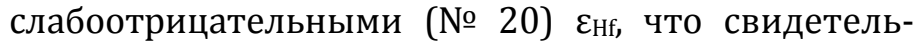



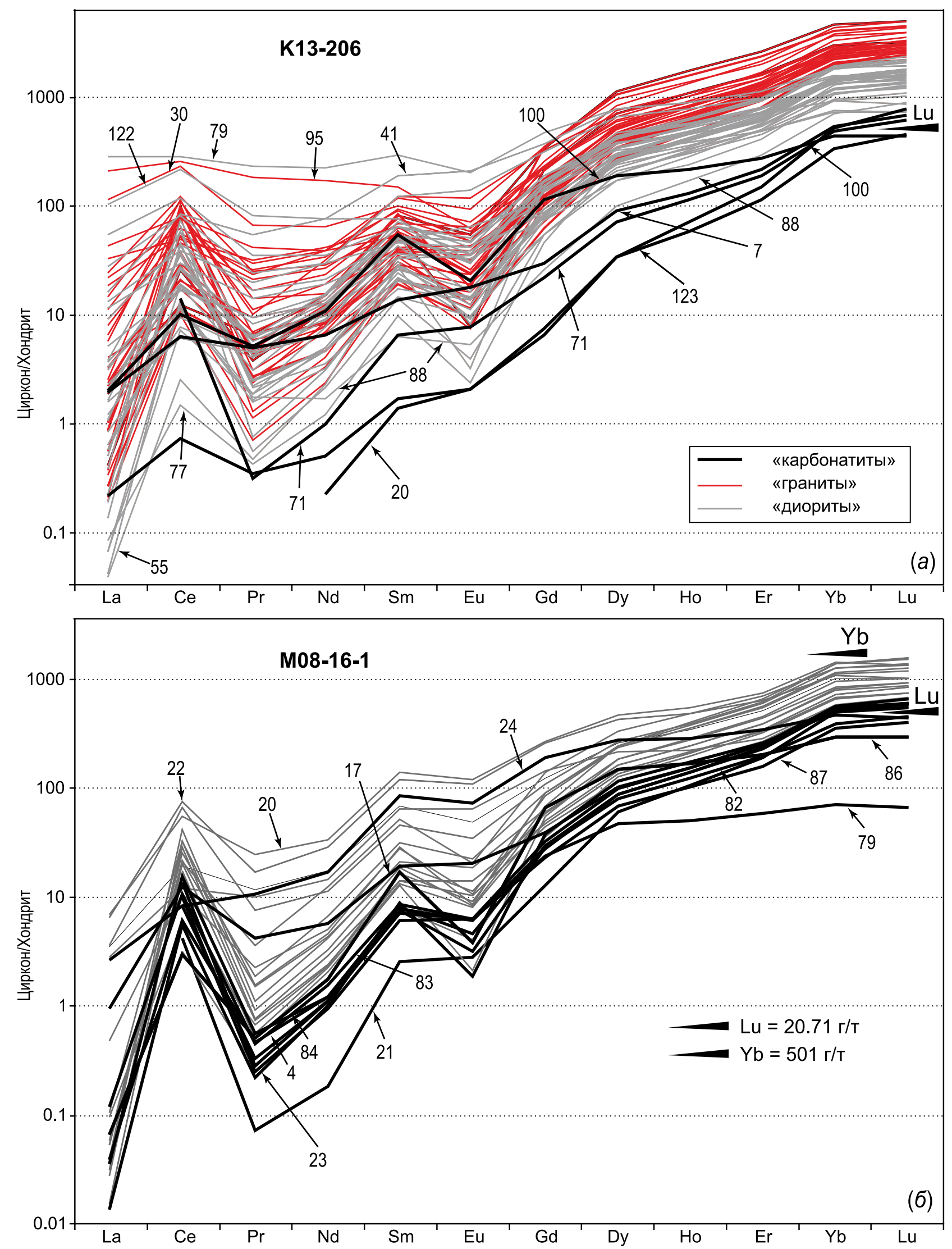

Рис. 7. Хондрито-нормализованные (CI-хондрит по [McDonough, Sun, 1995]) содержания редкоземельных элементов в детритовых цирконах из пробы К13-206 (a) и пробы M08-16 (б).

Fig. 7. Chondrite-normalized contents (CI-chondrite after [McDonough, Sun, 1995]) of REE elements in the detrital zircons from sample K13-206 (a) and sample M08-16 (б). 


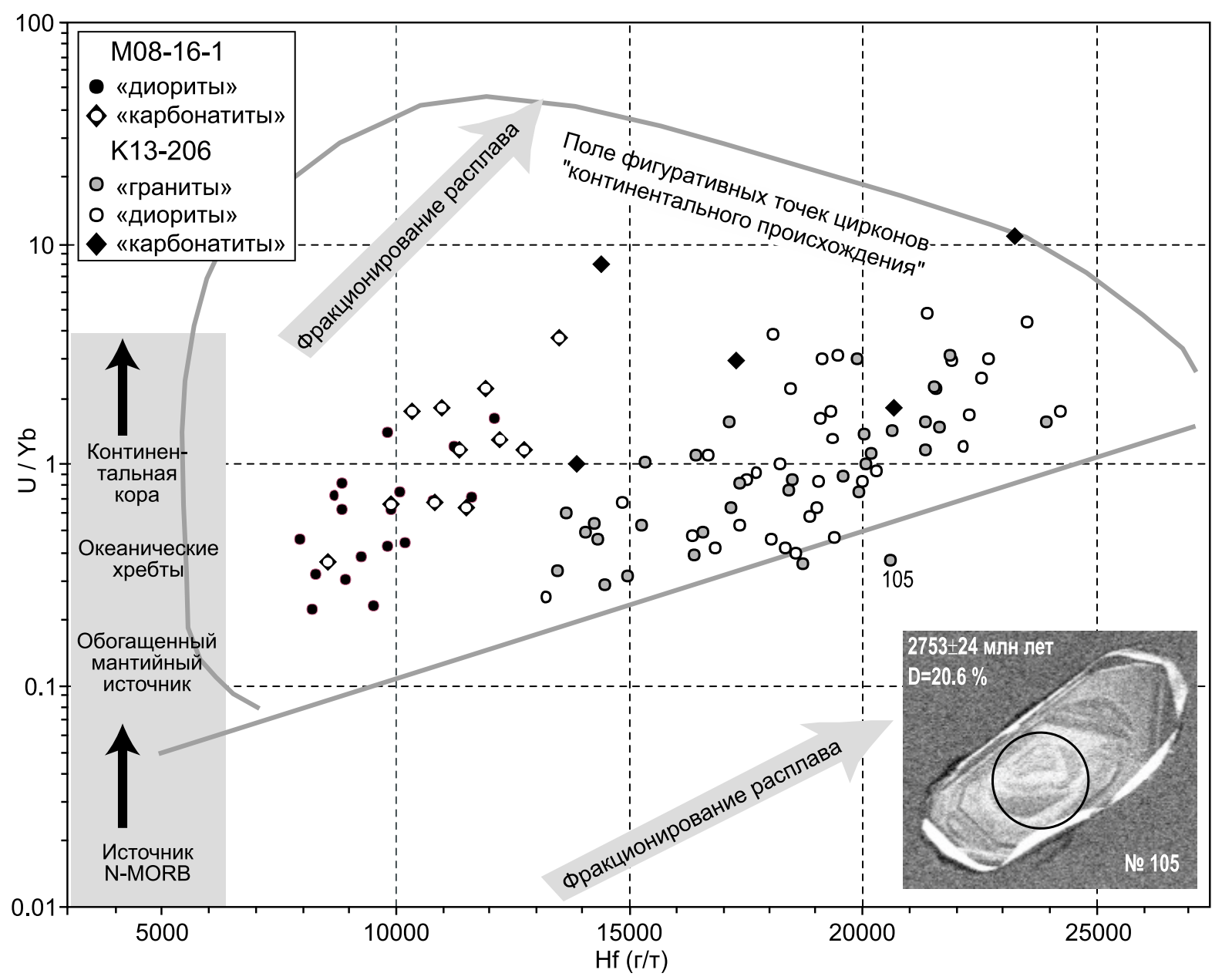

Рис. 8. Диаграммы отношений «U/YbvsHf» в детритовых цирконах из проб К13-206 и М08-16-1. Поля фигуративных точек, стрелки и надписи - по работе [Grimes et al., 2015, рис. 2].

Fig. 8. U/Yb vs Hf diagrams for the detrital zircons from samples K13-206 and M08-16-1. The fields of figurative points, arrows and legend after Fig. 2 in [Grimes et al., 2015].

ствует о преимущественно мантийном происхождении субстрата родительских пород этих цирконов, без существенной примеси изотопно-зрелого корового вещества, то есть в пробу К13-206 попали продукты разрушения карбонатитового комплекса с мантийным типом субстрата, активного около 2.05 млрд лет назад. В пробе М08-16-1 шесть «карбонатитовых» цирконов из группы КВП внешне очень похожи. Два из них (№ 83 и 84) имеют палеопротерозойский возраст ( 2.05 млрд лет), с учетом точности измерений фактически совпадающий с возрастом «карбонатитовых» цирконов из пробы К13-206. Остальные четыре циркона группы КВП № 79, 82, 86 и 87 вместе с «карбонатитовыми» цирконами № 4 и 21 формируют тренд с очень древними $\mathrm{T}_{\mathrm{DM}}^{\mathrm{C}}$, от 3.2 до 3.9 млрд лет, свидетельствующими о том, что в субстрате, из которого на рубежах около 3.6, 2.85, 2.5 и 2.05 млрд лет выплавлялись карбонатитовые магмы, родительские по отношению к этим цирконам, участвовал палеоархейский коровый материал.
В свете того, что по некоторым проблемам генезиса карбонатитов и их идентификации/классификации до сих пор не достигнут консенсус [Woolley, 2003; Mitchell, 2005; Woolley, Church, 2005; Woolley, Kjarsgaard, 2008; Sklyarov et al., 2009; Ernst, Bell, 2009; Jones et al., 2013; Rukhlov et al., 2015], а в некоторых работах даже сам принцип использования содержаний элементов-примесей в цирконах для прогнозирования типа родительских пород цирконов вообще ставится под сомнение [Hoskin, Ireland, 2000], совсем не лишним будет упомянуть о работе [Savva et al., 2010], в которой сообщается о результатах анализа содержаний 20 элементов-примесей (включая РЗЭ) в более чем 100 цирконах из карбонатитовых комплексов разного возраста по всему миру. Хотя среди изученных цирконов встречались цирконы с характеристиками, сильно отличными от «карбонатитовых» по классификации CART2000, все же почти половина проанализированных цирконов (45 \%) удовлетворила критериям CART2000. 


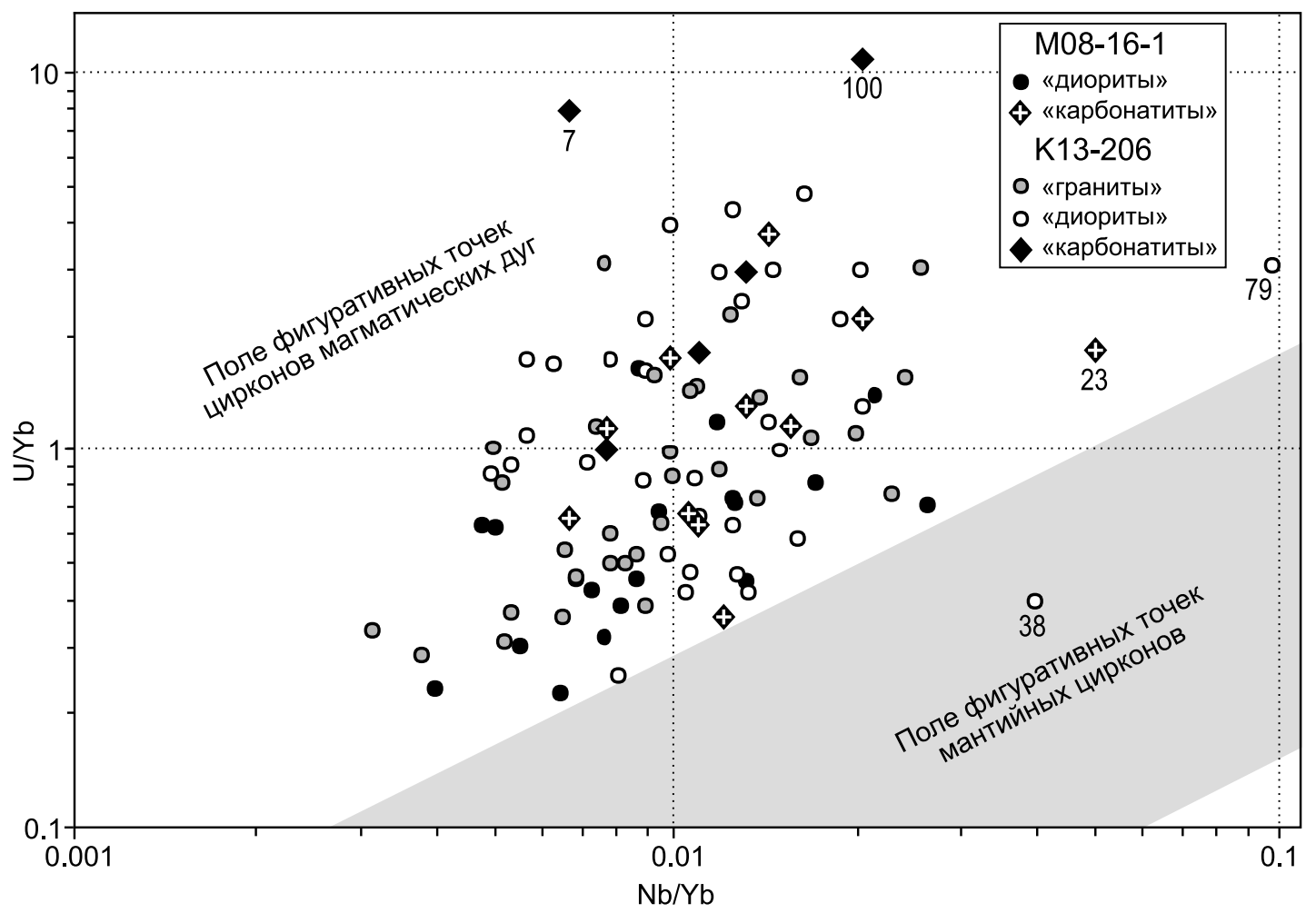

Рис. 9. Диаграммы отношений «U/YbvsNb/Yb» в детритовых цирконах из проб К13-206 и М08-16-1. Поля фигуративных точек - по работе [Grimes et al., 2015, рис. 6, c].

Fig. 9. U/Yb vs Nb/Yb diagrams for the detrital zircons from samples K13-206 and M08-16-1. The fields of figurative points after Fig. 6c in [Grimes et al., 2015].

И это очень хорошая статистика, так как критерии CART2000 разрабатывались для первичных магматических карбонатитов, сгенерированных из мантийных расплавов, а в протестированной коллекции были цирконы из очень разнообразных карбонатитовых пород, в том числе возможно подверженных коровой контаминации и вторичной метаморфической/гидротермальной переработке (цирконы с включениями, с метаморфическими оболочками, без CL-зональности и др.), т.е. процессам, которые могли сильно изменить первичные содержания элеменов-примесей в цирконе.

В обеих пробах по содержаниям элементовпримесей как «карбонатитовые» идентифицированы не единичные цирконы, а группы цирконов, схожесть которых между собой подтверждается также одинаковым возрастом (№ 7, 20, 71 и 123 в пробе К13-206) либо внешней схожестью и уникально древними $\mathrm{T}_{\mathrm{DM}}^{\mathrm{C}}$ (проба M08-16-1, группа КВП); это делает интерпретацию гораздо более надежной. Во всяком случае, нет сомнений в происхождении этих двух групп цирконов из двух различных очень специфических источников, даже если ставить под сомнение их «карбонатитовый» тип.

Буквально до недавнего времени не были известны карбонатитовые комплексы с возрастом древнее 2.7 млрд лет [Woolley, Kjarsgaard, 2008; Jones et al., 2013], однако сейчас этот рубеж уже 3.01 млрд лет (см. [Rukhlov et al., 2015]). К возрасту 2.0 и 2.5 млрд лет «карбонатитовых» цирконов из пробы К13-206 близок возраст карбонатитов из таких известных комплексов, как Фалаборва (Phalaborwa), Бушвельд, Каапвальский кратон ( 2.06 млн лет [Wu et al., 2011], Тикшеозеро (Tiksheozero) и Сиилинярви (Siilinjärvi), Карелия, Балтийский щит ( 2.0 и 2.6 млрд лет млрд лет [Corfu et al., 2011; Tichomirowa et al., 2012]), кратона Слэйв ( 2.6 млрд лет [Villeneuve, Relf, 1998]). При этом фиксируются хорошие соответствия не только возраста, но и параметров Hf изотопии, в то время как для «карбонатитовых» цирконов из пробы М08-16-1 совпадений даже по возрасту с известными данными нет (рис. 14). Таким образом, «карбонатитовые» цирконы с возрастом около 2.85 и 3.6 млрд лет - это косвенные следы очень древних эпизодов карбонатитового магматизма, хотя сами комплексы, возможно, не сохранились или пока неизвестны.

Из пяти цирконов группы ПЖ (все классифицированные как «диоритовые») два имеют архейский возраст 2.1 и 2.85 млрд лет, а три - близкий палеопротерозойский 2.1 млрд лет. Два палеопротерозойских циркона показали существенно поло- 


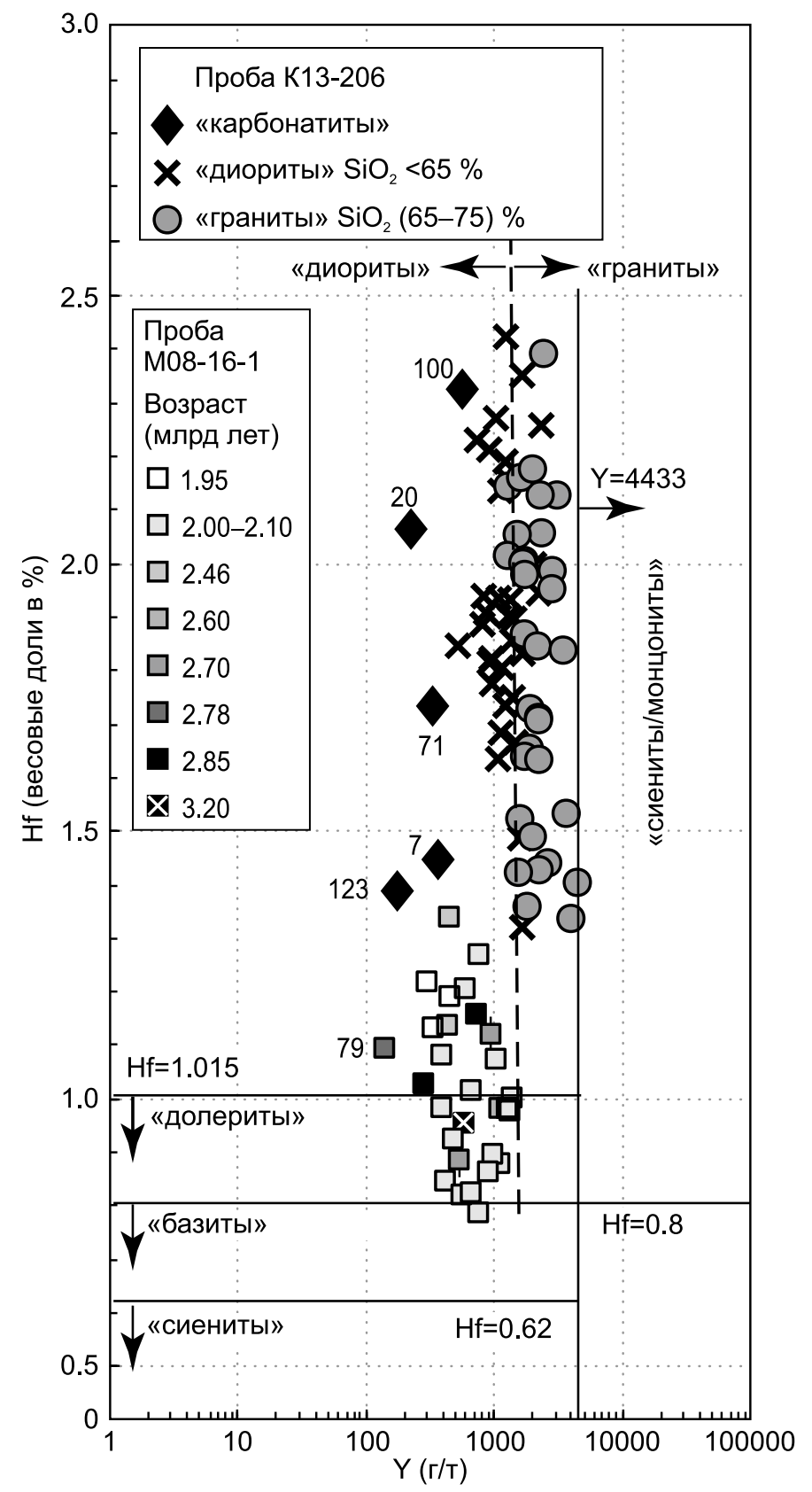

Рис. 10. Диаграммы содержаний «Hf vs Y» в детритовых цирконах из проб К13-206 и М08-16-1. Все цирконы из пробы М08-16-1 классифицированы как происходящие из «диоритов» или «карбонатитов», для них специальными значками показан U/Pb возраст.

Fig. 10. Diagrams of Hf vs Y concentrations in the detrital zircons from samples K13-206 and M08-16-1. All the zircons from sample M08-16-1 are classified as originating from diorites or carbonatites. Their $\mathrm{U} / \mathrm{Pb}$ ages are shown by special symbols.

жительные величины $\varepsilon_{\mathrm{Hf}}$ и $\mathrm{T}_{\mathrm{DM}}^{\mathrm{C}} \sim 2.25$ млрд лет, а фигуративные точки для трех других цирконов на диаграмме $\varepsilon_{\mathrm{Hf}}$ формируют тренд с $\mathrm{T}_{\mathrm{DM}}^{\mathrm{C}} \sim 3.2$ млрд лет (внутри общего тренда архейских «некарбонатитовых» цирконов $\mathrm{T}_{\mathrm{DM}}^{\mathrm{C}} \sim 2.8-3.4$ млрд лет). Нельзя исключить того, что тренд - это не случайность, и именно специфический мезоархейский материал, который вовлекался в магматический субстрат на рубежах около 3.1, 2.85 и 2.1 млрд лет, когда выплавлялись родительские магмы цирконов, ответствен за желтый цвет и прозрачность цирконов группы ПЖ.

На классификационной диаграмме, позволяющей отличать цирконы из океанических базальтов от цирконов из пород континентального генезиса (см. рис. 8), только один циркон - № 105 из пробы К13-206 - отчетливо выпал из поля цирконов «континентального происхождения». Все остальные цирконы, наиболее вероятно, имеют внутриконтинентальное или окраинно-континентальное происхождение. На классификационной диаграмме, позволяющей отличать мантийные цирконы от цирконов из океанических дуг (см. рис. 9), только один циркон - № 38 из пробы К13-206 - попал в поле «мантийных цирконов».

Четкое отличие между пробами фиксируется по содержаниям Hf в цирконах (см. рис. 8 и 10): в цирконах из пробы К13-206 содержания Hf от 1.3 до $2.4 \%$, в то время как в цирконах из пробы М08-16-1 - от 0.8 до $1.45 \%$. Все это указывает на то, что в пробе М08-16-1, по сравнению с пробой К13-206, бо́льшую роль играют цирконы, произошедшие из менее кремнекислых и/или щелочных/сиенитовых родительских пород.

Цирконы из «диоритов»и «гранитов» разделяются не только по сумме РЗЭ (см. рис. 6 и 7), но также довольно хорошо по содержанию Y (пограничное значение 1200 г/т) (см. рис. 10 и 12).

По классификационным параметрам Th/U (cм. рис. $11, a, \sigma)$, величинам Се- и Еu-аномалий (см. рис. $11,8,2)$, отношениям $\mathrm{Yb} / \mathrm{Sm}$ (см. рис. $12, a$, б) заметных отличий между цирконами из проб К13-206 и м08-16-1 не выявлено, на всех диаграммах их поля фактически перекрываются. Лишь в пробе К13-206 фиксируется наличие группы цирконов с относительно повышенными содержаниями $\mathrm{Nb}$ и Та (cм. рис. 12, в, г) по сравнению с пробой М08-16-1. Попытка выявить какие-либо зависимости или тренды между содержаниями элементов-примесей и возрастом цирконов в обеих пробах не привела к успеху. Примеры таких диаграмм показаны для цирконов из пробы М08-16-1 (см. рис. 10-12).

Сопоставление фигуративных точек на «диа-

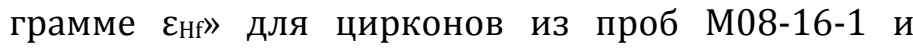
К13-206 с известными значениями возраста и изотопно-геохимическими признаками кристаллических комплексов волго-уральской части ВЕП (см. рис. 13) выявило следующее.

(1) Фигуративные точки ни в пробе К13-206, ни в пробе М08-16-1 не показали статистически значимых совпадений с полями комплексов Бакалин- 

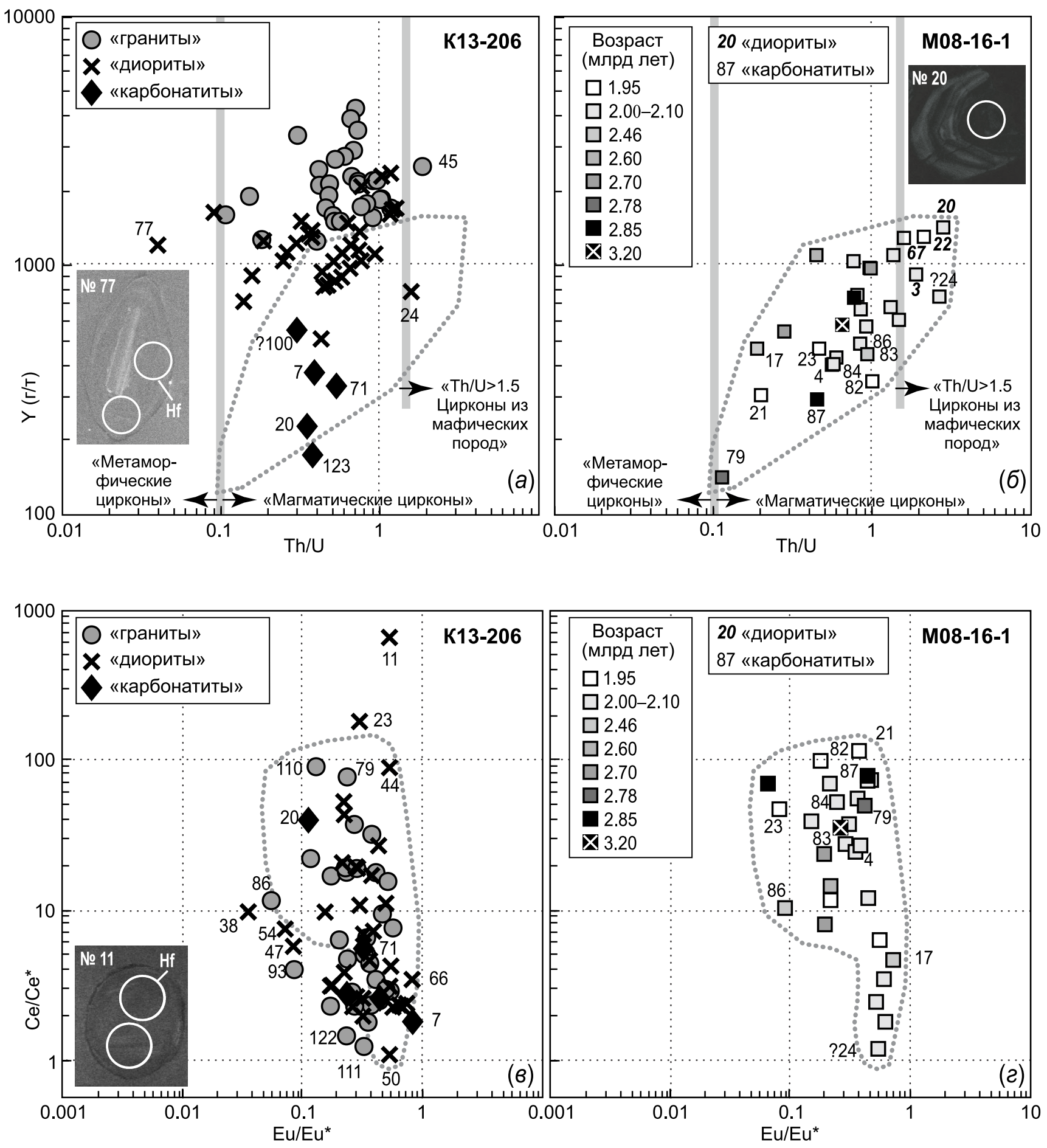

Рис. 11. Диаграммы содержаний «Y vs $\mathrm{Th} / \mathrm{U} »\left(a\right.$, б) и «Ce/Ce* vs $\mathrm{Eu} / \mathrm{Eu}^{*} »(8,2)$ в детритовых цирконах из проб К13-206 и M08-16-1. Для пробы М08-16-1 все цирконы классифицированы как происходящие из «диоритов» или «карбонатитов». Для облегчения сопоставления данных по пробам точечная серая линия, оконтуривающая поля значений для пробы М08-16-1, показана и на диаграммах для пробы К13-206.

Fig. 11. Diagrams of $\mathrm{Y}$ vs $\mathrm{Th} / \mathrm{U}(a, \sigma)$ and $\mathrm{Ce} / \mathrm{Ce}^{*}$ vs $\mathrm{Eu} / \mathrm{Eu}^{*}(b, 2)$ concentrations in the detrital zircons from samples K13-206 and M08-16-1. All the zircons from sample M08-16-1 are classified as originating from diorites or carbonatites. To facilitate the data comparison between the samples, the grey dotted contour of the field of values for sample M08-16-1 is also shown in the diagrams for sample K13-206.

ского блока (комплексы Ташлярский, Бак-1, Бак-2, Актанышский), а также с колыванскими эндербитами.
(2) Многие фигуративные точки для пробы К13-206 близки или попали в поле изотопных параметров пород южной части Волго-Сарматского 

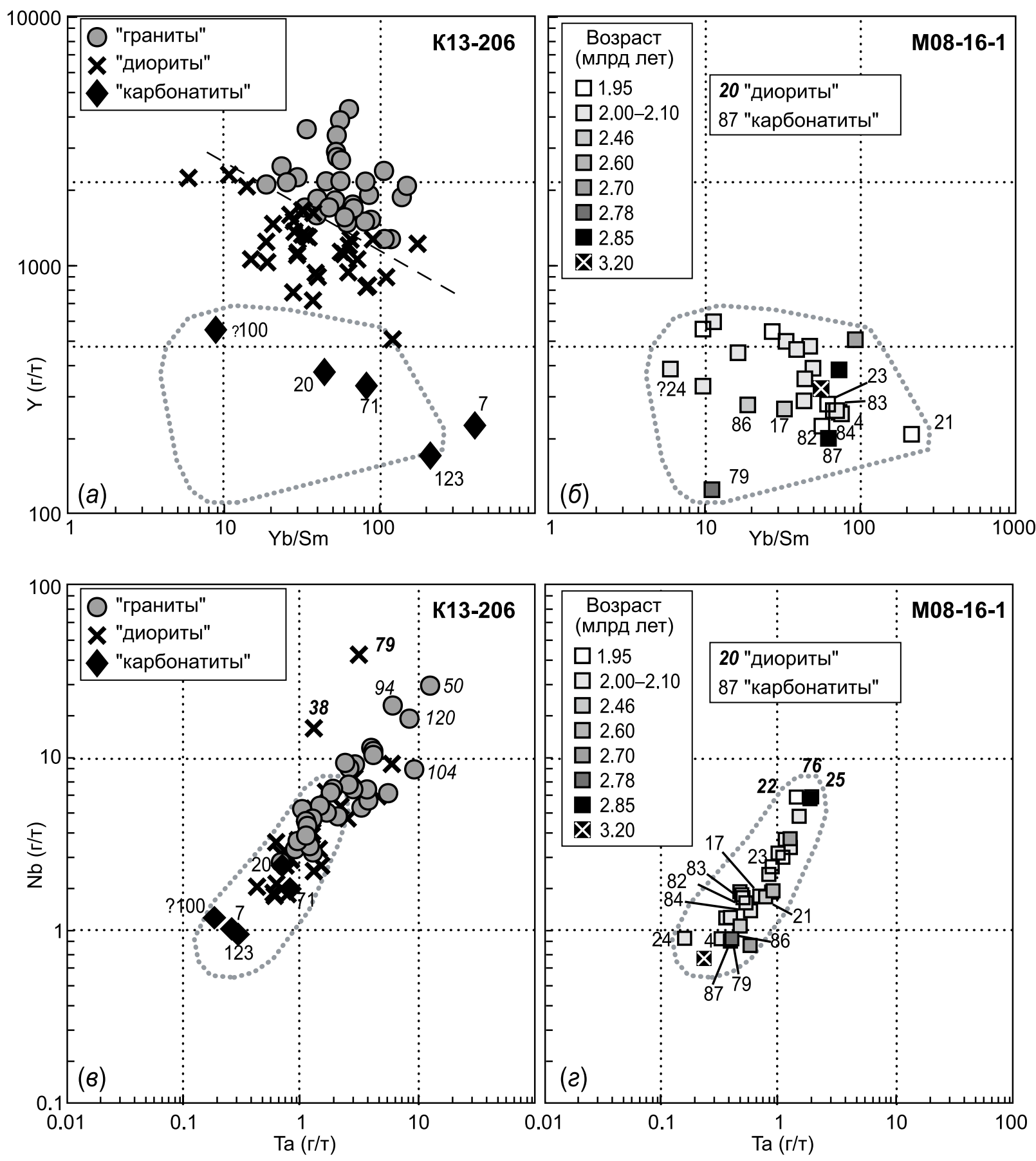

Рис. 12. Диаграммы содержаний «Nb vs Ta» и «Y vs $\mathrm{Yb} / \mathrm{Sm} »$ в детритных цирконах из пробы K13-206 (a, в) и пробы M08-16-1 (б, 2). Для пробы М08-16-1 все цирконы классифицированы как происходящие из «диоритов» или «карбонатитов». Для облегчения сопоставления данных по пробам точечная серая линия, оконтуривающая поля значений для пробы М08-16-1, показана на диаграммах для пробы К13-206. Пунктирная линия на (a) разделяет «граниты» и «диориты».

Fig. 12. Diagrams of $\mathrm{Nb} v s \mathrm{Ta}$ and $\mathrm{Y} v s \mathrm{Yb} / \mathrm{Sm}$ concentrations in the detrital zircons from samples $\mathrm{K} 13-206(a, 8)$ and M08-16-1 $(6,2)$. All the zircons from sample M08-16-1 are classified as originating from diorites or carbonatites. For an easier comparison between the samples, the grey dotted contour of the field of values for sample M08-16-1 is also shown in the diagrams for sample K13-206. In Fig. 12 (a), the dashed line separates granites and diorites.

коллизионного орогена (далее «поле ВСО»), а несколько фигуративных точек цирконов из пробы М08-16-1 попали в нижнюю часть «поля ВСО».
(3) Фигуративные точки, соответствующие палеопротерозойскому возрасту 1.9-2.2 млрд лет, с размахом изменений значений $\varepsilon_{\mathrm{Hf}}$ от максималь- 

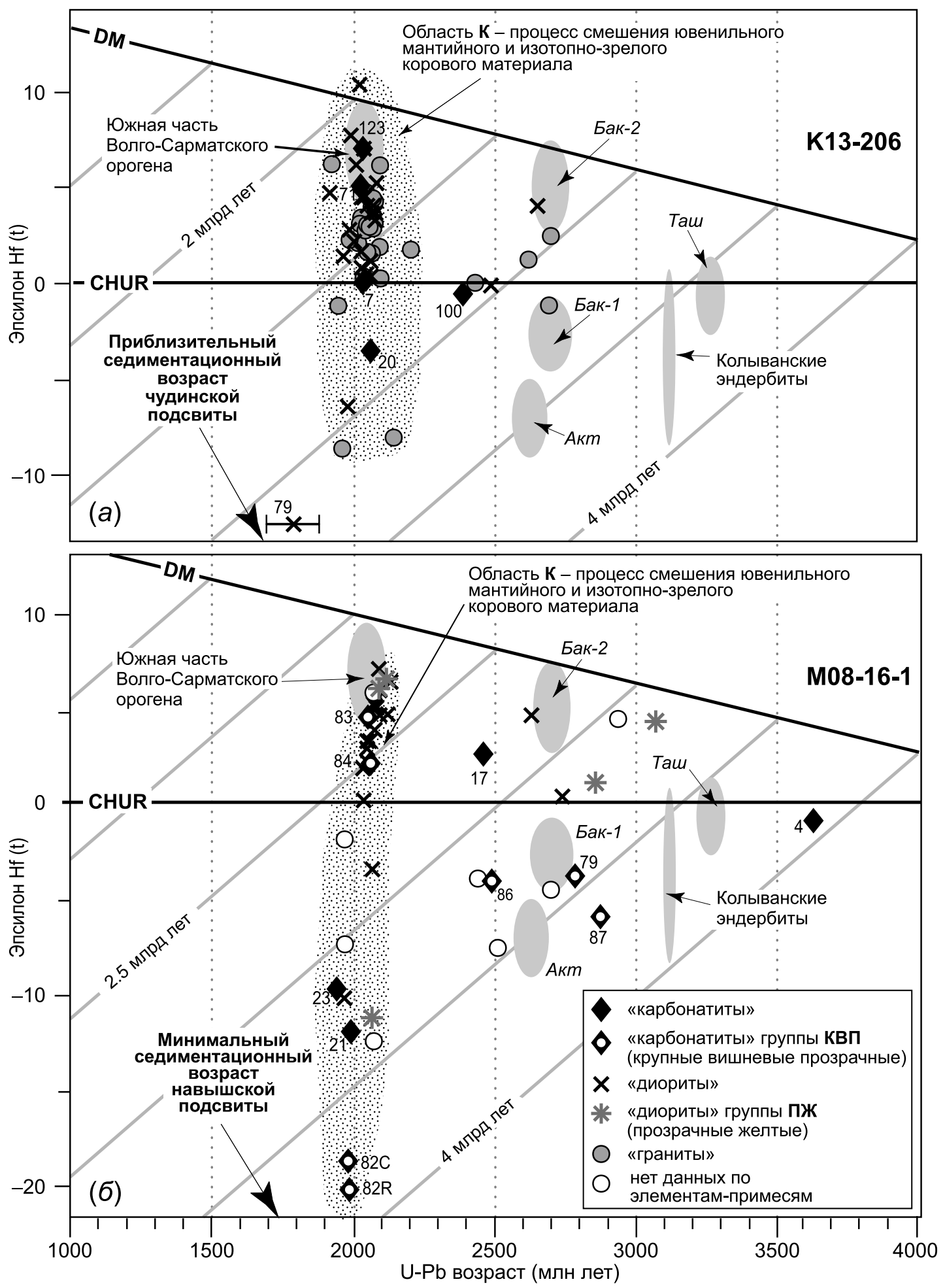

Рис. 13. Диаграммы $\varepsilon_{\mathrm{Hf}}$ для пробы К13-206 (a) и M08-16-1 (б). Серые эллипсы - поля фигуративных точек возрастов и $\mathrm{T}_{\mathrm{DM}}$, оцененных по Sm/Nd изотопной системе, для Бакалинского блока Волго-Уралии (комплексы: Таш - Ташлярский, Бак-1, Бак-2 и Акт - Актанышский) по [Bogdanova et al., 2010], для южной части Волго-Сарматского орогена, спаявшего Волго-Уралию и Сарматию («поле ВСО») - по [Bibikova et al., 2009]), для колыванских эндербитов - по [Bogdanova et al., 2013].

Fig. 13. Diagrams $\varepsilon_{\mathrm{Hf}}$ for sample K13-206 (a) and sample M08-16-1 (б). Grey ellipses show the fields of figurative points of ages and $\mathrm{T}_{\mathrm{DM}}$ estimated from the $\mathrm{Sm} / \mathrm{Nd}$ isotopic system for the Bakalin block of the Volga-Ural region (Taw - Tashlyar, Бак-1, Бак-2, and Акт - Aktanysh complexes) after [Bogdanova et al., 2010], the southern part of the Volga-Sarmatia orogen that joined the Volga-Ural and Sarmatia regions, (BCO field) - after [Bibikova et al., 2009]), and the Kolyvan enderbites after [Bogdanova et al., 2013]. 
Сводка характеристик цирконов, классифицированных как «карбонатитовые»

The characteristics of 'carbonatite' zircons

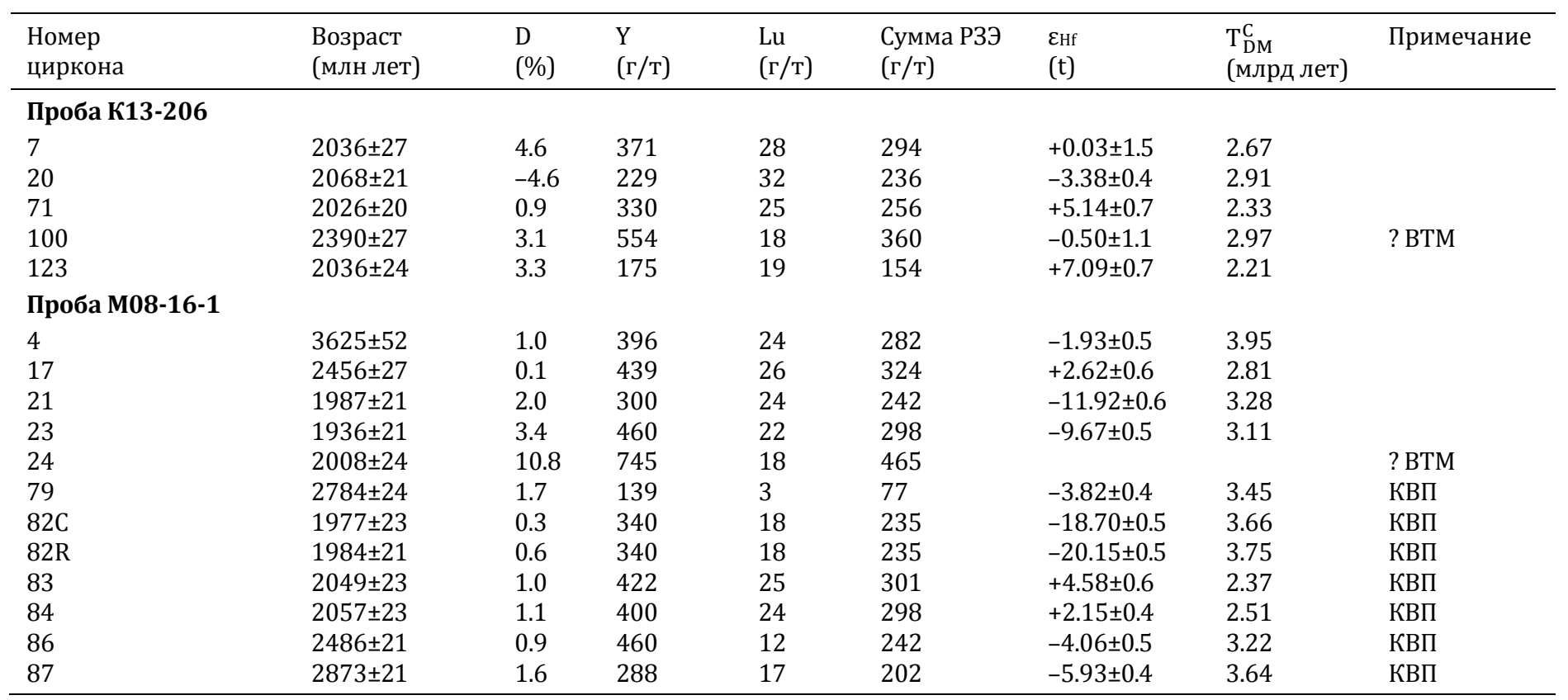

П р и м е ч а н и е. КВП - однотипные (крупные вишневые прозрачные) цирконы. ? ВТМ - неуверенная классификация, возможно, что эти цирконы - продукт высокотемпературного метаморфизма в присутствии граната.

N o t e. КВП - large-size transparent cerise-colour zircons. ? BTM - classified with uncertainty: these zircons may be a product of high-temperature metamorphism in the presence of garnet.

ных положительных - линия DM - до отрицательных значений, соответствующих модельному возрасту до 3.2 млрд лет для пробы К13-206 (рециклинг мезоархейской коры) и до 3.9 млрд лет для пробы М08-16-1 (рециклинг палеоархейской коры), выстраиваются в вертикально вытянутые области (ряды) - далее области К. Области К интерпретируются как отражающие результат смешения в разных пропорциях ювенильного и изотопно-зрелого корового материала, которое может происходить в длительно действующих вулканических дугах на окраинах континентов и/или в коллизионных орогенах. В данном случае орогены палеопротерозойские. Очевидно, что в областях К могут быть представлены не только цирконы, сгенерированные в орогенах.

(4) Попадание фигуративных точек из проб К13206 и М08-16-1 в «поле ВСО», а самого «поля ВСО» в области К позволяет соотносить области К с ВСО.

\section{9. ГЕОДИНАМИЧЕСКАЯ И ПАЛЕОГЕОГРАФИЧЕСКАЯ ИНТЕРПРЕТАЦИЯ ПОЛУЧЕННЫХ ДАННЫХ}

Развитие рифейского осадочного бассейна, реликты которого представлены в современной структуре БП и приняты за стратотип рифея, соответствует заключительным стадиям существова- ния и распада суперконтинента Колумбия (в некоторых работах - Нуна (Nuna), Гудзонлэнд (Hudsonland), Прото-Родиния (Proto-Rodinia) и др. [Roger, Santosh, 2002; Meert, 2002; Zhao et al., 2002; Evans, Mitchell, 2011]), сформированного в палеопротерозое из архейских блоков (протократонов) (рис. 15). Неопределенность палеомагнитных данных и небольшое количество изотопных датировок, которые составляли основу позиционирования протократонов в ранних реконструкциях Колумбии, приводили к их различной позиции в суперконтиненте. Так, в некоторых реконструкциях территория, где в настоящее время располагается БП, оказывалась пассивной окраиной Колумбии [Zhao et al., 2004], в других конфигурациях она была внутренней частью Колумбии [Pesonen et al., 2003]. Однако в последнее время стремительно возросший объем высокоточных геохронологических датировок (в том числе датирование даек) внес существенные ограничения на возможные взаимные расположения протократонов в составе Колумбии, и в современных в гораздо большей степени обоснованных моделях Колумбии волго-уральский сегмент Балтики располагается во внутренней части Колумбии [Evans, Mitchell, 2011; Zhang et al., 2012; Pisarevsky et al., 2014; Ernst et al., 2016].

На классификационной диаграмме (см. рис. 8) все фигуративные точки для изученных цирконов 


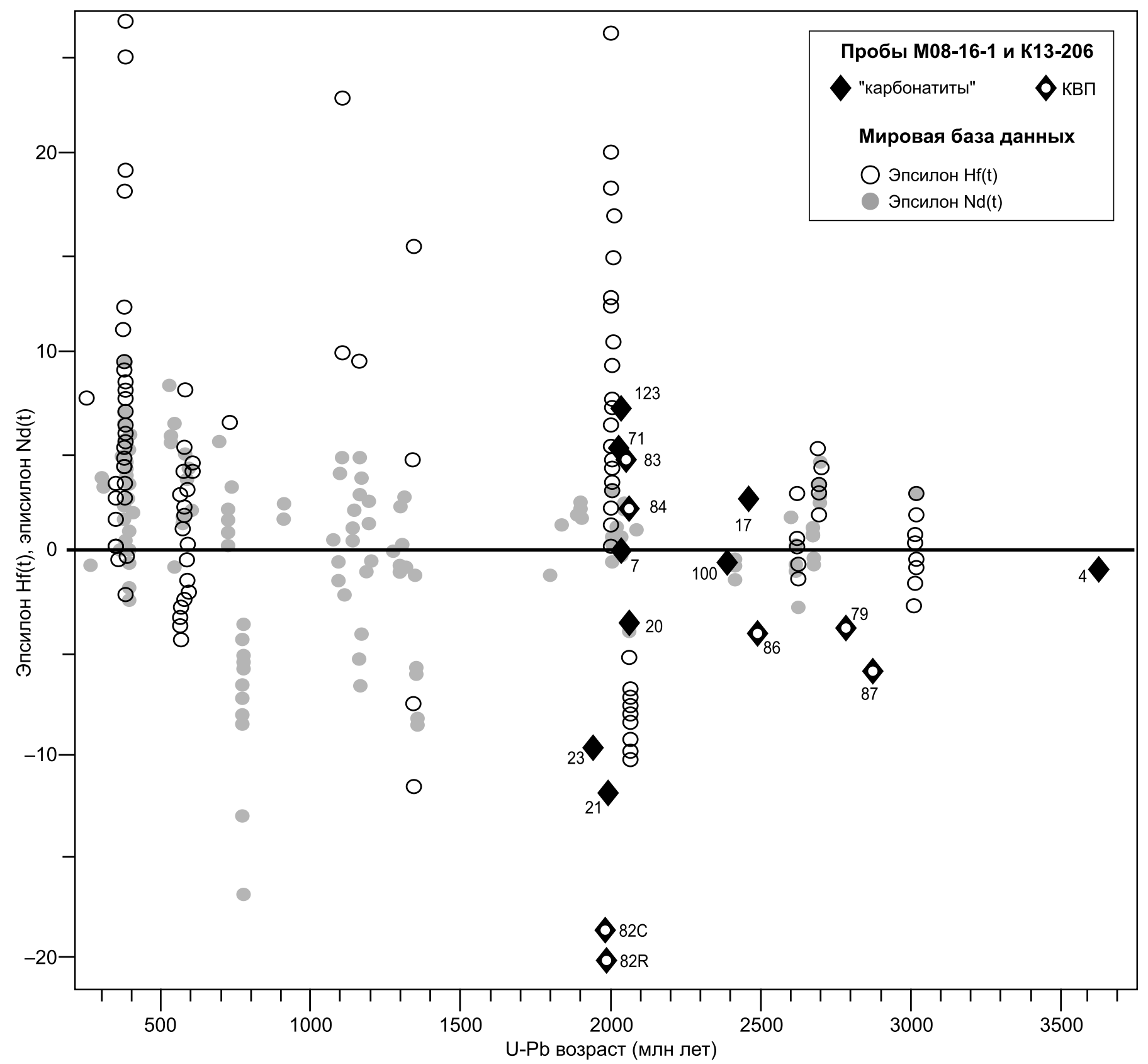

Рис. 14. Диаграмма «U/Pb-изотопный возраст - Эпсилон $\mathrm{Hf}(\mathrm{t})$ и Эпсилон $\mathrm{Nd}(\mathrm{t}) »$ мировой базы данных по карбонатитам по [Rukhlov et al., 2015] с упрощениями (показаны только карбонатиты древнее 250 млн лет), на которую добавлены данные по «карбонатитовым» цирконам из проб К13-206 и М08-16-1.

Fig. 14. The $\mathrm{U} / \mathrm{Pb}$-isotope age - Epsilon $\mathrm{Hf}(\mathrm{t})$ and Epsilon $\mathrm{Nd}(\mathrm{t})$ diagram. The world database on carbonatites after $[$ Rukhlov et al., 2015] (modified, only carbonatites older than $250 \mathrm{Ma}$ are shown). The data on "carbonatite" zircons from samples K13-206 and M08-16-1 are added.

из айской свиты, за исключением одной, располагаются в поле цирконов «континентального происхождения». Это свидетельствует о малой роли комплексов океанического или окраинно-морского генезиса среди первичных источников цирконов, т.е. наши данные лучше согласуются с внутриконтинентальным, а не окраинно-континентальным расположением рифейского бассейна, базальные уровни которого выполнены айской свитой.
В «протобалтийскую» часть Колумбии входили, по данным корреляции палеопротерозойских складчатых поясов и результатам палеомагнитных исследований, протократоны Кола, Карелия, Сарматия и Волго-Уралия и сформированный в начале раннего протерозоя Свеко-Фенский блок (рис. 16). За счет их последовательного сутурирования коллизионными орогенами в палеопротерозое сформировалась кратоническая часть фундамента ВЕП 


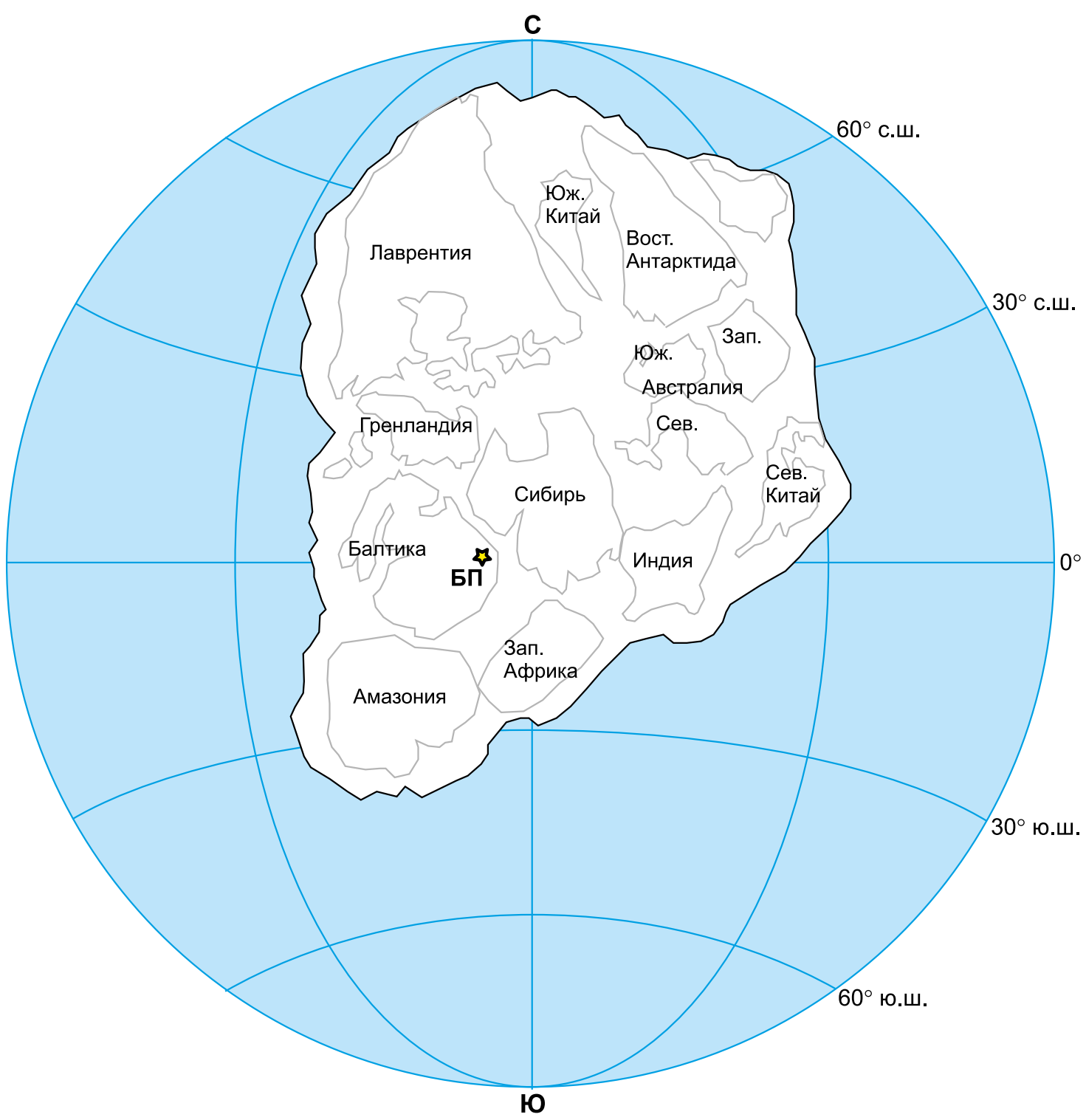

Рис. 15. Одна из реконструкций суперконтинента Колумбия на временной рубеж 1.59 млрд лет (по [Evans, Mitchel, 2011], с упрощениями). Примерное положение Башкирского поднятия (БП) показано звездочкой.

Fig. 15. A reconstruction of the supercontinent Colombia (1.59 Ga) (modified after [Evans, Mitchel, 2011]). The star marks an approximate position of the Bashkir Uplift (БП).

[Bogdanova et al., 2008], причем Волго-Уралия и Сарматия сутурированы Волго-Сарматским коллизионным орогеном (ВСО), спаявшим их в ВолгоСарматию приблизительно 2.1-2.0 млрд лет назад [Bibikova et al., 2009; Terentiev et al., 2016].

Результаты многолетних геолого-геофизических исследований Южного Урала и прилегающих регионов ВЕП не оставляют сомнений в том, что тараташский комплекс - это часть кристаллического основания ВЕП и в тектоническом смысле трактуется как «выступ Волго-Уралии» [Puchkov, 2010]. Судя по стратиграфическому характеру налегания айской свиты на тараташский комплекс, именно волгоуральская часть ВЕП, определенно, должна была быть источником кластики для слагающих ее песчаников.

Полученные в самое последнее время тектонические, геохимические и геохронологические данные свидетельствуют о том, что в тараташском комплексе активно проявлены палеопротерозойские метаморфические преобразования и посткинематические гранитоиды (см. обзор в [Tevelev et $a l ., 2015])$. Вместе с анализом характеристик детритовых цирконов из рифейских толщ БП это позволило интерпретировать тараташский комплекс как реликт палеопротерозойского Тараташского орогена (T0) [Kuznetsov et al., 2017]. Этот ороген в структуре Колумбии мог включать коровые блоки 


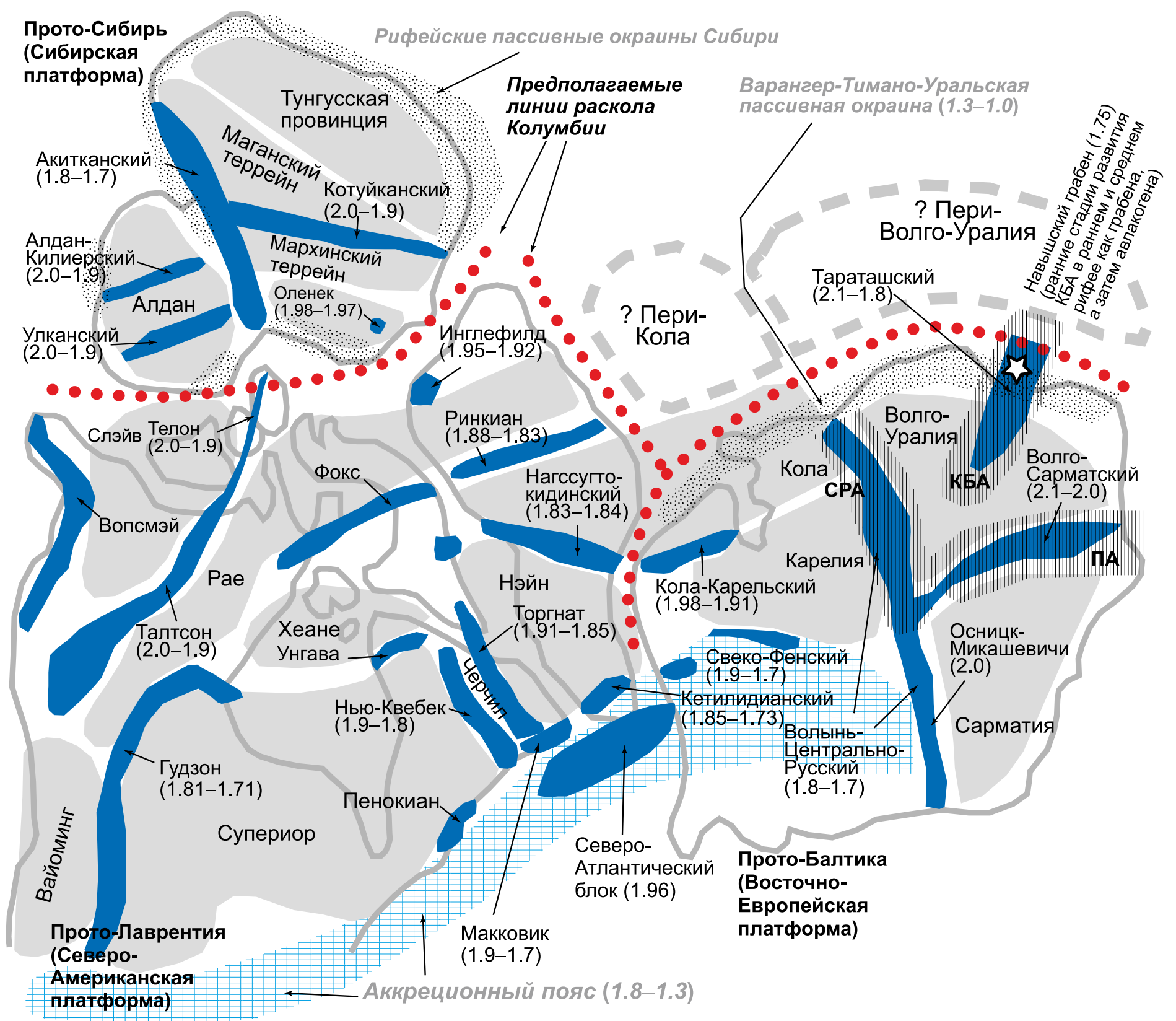

Рис. 16. Фрагмент компоновки архейских блоков/протократонов (светло-серые области), спаянных палеопротерозойскими орогенами (темно-синие области) в суперконтиненте Колумбия (рубеж палео-и мезопротерозоя), включающий Прото-Балтику, Прото-Лаврентию и Прото-Сибирь (основа рисунка по [Zhao et al., 2004]). Цифры - возраст, млрд лет. Примерное положение Башкирского поднятия показано звездочкой. Авлакогены (показаны вертикальной штриховкой): ПА - Пачелмский, КБА - Камско-Бельский, СРА - Среднерусский. Все палеопротерозойские орогены, за исключением ВСО и ТО, характеризуются датировками <2.0 млрд лет, и только для ВСО и ТО, которые являются старейшими из этих орогенов и ближайшими к БП, получен возраст 2.1-2.0 млрд лет.

Fig. 16. Pattern of the Archaean blocks/protocratons (light gray areas) joined by the Paleo-Proterozoic orogens (dark blue areas) in the supercontinent Columbia (at the boundary of the Paleo- and Meso-Proterozoic), including Proto-Baltic, ProtoLaurentia and Proto-Siberia (based on the figure from [Zhao et al., 2004 ]). Numbers show ages (Ga). The star marks an approximate position of the Bashkir Uplift (БП). Aulacogenes (marked by vertical hatching): ПА - Pachelma, КБА - КаmaBelaya, CPA - Sredne-Russky. The Paleo-Proterozoic orogens (except BCO and TO) are <2.0 Ga old. Orogens BCO and TO are the oldest: $2.1-2.0 \mathrm{Ga}$.

в составе Волго-Уралии и гипотетического конгломерата континентальных коровых блоков, названного Пери-Волго-Уралия (рис. 16). Большинство на- дежных изотопных датировок, которые так или иначе можно соотносить с ТО, заключены в диапазоне 2.1-1.8 млрд лет [Tevelev et al., 2015, 2017]. 
Древнее ядро волго-уральской части фундамента ВЕП (протократон Волго-Уралия) сложено преимущественно раннепротерозойскими и архейскими комплексами, диапазон значений возраста которых от 2.1 до 3.5 млрд лет [Mints et al., 2010; Bogdanova et al., 2008], а с учетом структур обрамления Волго-Уралии совокупный диапазон возраста кристаллических комплексов всей юго-восточной (волго-уральской) части фундамента ВЕП охватывает период от $\sim 1.75$ до 3.5 млрд лет. При этом возраст в диапазоне 2.2-2.4 млрд лет очень редкий как для волго-уральской части, так и для всей ВЕП. Хотя изотопно-геохимические характеристики отдельных кристаллических комплексов фундамента волго-уральской части ВЕП не показали очевидных совпадений с таковыми изученных детритовых цирконов (что позволило бы идентифицировать эти комплексы как локальные источники), в целом диапазон наиболее древних возрастов обломочных цирконов из изученных проб К13-206 и М08-16-1 соответствует возрастному диапазону известных кристаллических комплексов протократона ВолгоУралия.

Сам по себе $\mathrm{U} / \mathrm{Pb}$-изотопный возраст архейских цирконов не позволяет идентифицировать, какой именно протократон был их источником. Однако наши данные по изотопии Hf в детритовых цирконах зафиксировали уникальный очень древний (>3.5 и до 3.95 млрд лет) модельный возраст корового субстрата материнских по отношению к изученным детритовым цирконам пород (см. рис. 13) и позволяют с высокой степенью вероятности идентифицировать в качестве основного поставщика архейских цирконов в айскую свиту именно волго-уральскую и соседние с ней части ВЕП. Аналогичный вывод был сделан и для цирконов из верхнерифейских песчаников БП [Romanyuk et al., 2013].

Доминирование среди изученных цирконов зерен с раннепалеопротерозойским возрастом (с пиковыми значениями $\sim 2055$ и 2064 млн лет) указывает на то, что среди кристаллических комплексов, первичных источников обломочного материала, продукты разрушения которых попали в раннерифейский осадочный бассейн, где накапливались песчаники айской свиты, преобладали раннепалеопротерозойские образования. К настоящему времени накоплен уже большой объем геохронологических датировок кристаллических пород палеопротерозойских орогенов в пределах протосибирской, протолаврентийской и протобалтийской частей Колумбии, которые свидетельствуют о том, что все они характеризуются возрастом <2.0 млрд лет (рис. 16). И только для ВСО и ТО, которые являются старейшими из этих орогенов и ближайшими к БП, получен возраст 2.1-2.0 млрд лет. По- скольку в песчаниках из айской свиты доминируют раннепротерозойские зерна с возрастом >2 млрд лет, есть все основания считать ВСО и ТО их наиболее вероятными источниками.

Айская свита формировалась более чем через 200 млн лет после пика активности ВСО и ТО. К этому времени орогены уже не существовали как высокостоящие горные сооружения, а их реликты (кристаллические комплексы их глубинных частей) стали частью фундамента ВЕП. Однако палеопротерозойские цирконы в пробах К13-206 и M08-16-1 доминируют по сравнению с продуктами разрушения архейских доменов фундамента ВЕП. Это свидетельствует о том, что айская свита определенно формировалась не только за счет непосредственного размыва кристаллических комплексов фундамента ВЕП, но и за счет перемыва осадочных отложений, включая молассу раннепалеопротерозойских орогенов, в которых был аккумулирован значительный объем первичных продуктов их разрушения.

Начавшийся на рубеже 1.75-1.70 млрд лет распад Колумбии привел в конечном итоге к вычленению из нее Прото-Балтики и заложению на ВЕП авлакогенов, пространственно наследующих раннепротерозойские коллизионные орогены [Bogdanova et al., 2008]. В частности, вдоль ВСО заложился Пачелмский авлакоген, а вдоль ТО стал развиваться Камско-Бельский авлакоген, который начал свое развитие как Навышский грабен [Gorozhanin et al., 2014].

Особенности и схожесть набора возрастов цирконов в пробах К13-206 и М08-16-1, а также существенные геохимические и Hf-изотопные отличия в характеристиках цирконов из проб К13-206 и М08-16-1 могут быть объяснены в рамках модели формирования айской свиты в Навышском грабене. На самой начальной стадии рифтогенеза (рис. $17, a$ ) в Навышском грабене формировалась толща грубообломочных пород (навышская подсвита, охарактеризованная пробой М08-16-1), накопление которых происходило на фоне и в результате обрушения и размыва образовавшихся тектонических уступов, с последующим разносом кластики временными потоками и реками. В основную стадию рифтогенеза, в условиях аллювиально-прибрежного мелководья, произошли мощные трещинные излияния щелочных базальтов. В завершающую стадию рифтогенеза (рис. 17, б) формировались песчаники липовской толщи, конгломераты и песчаники чудинской подсвиты (проба К13-206) и углеродистые сланцы верхов разреза чудинской и кисеганской подсвит, заполнившие и перекрывшие грабен. Чудинская и кисеганская подсвиты формировались, по-видимому, уже на начальных стадиях развития Камско-Бельского авлакогена. Общая по- 


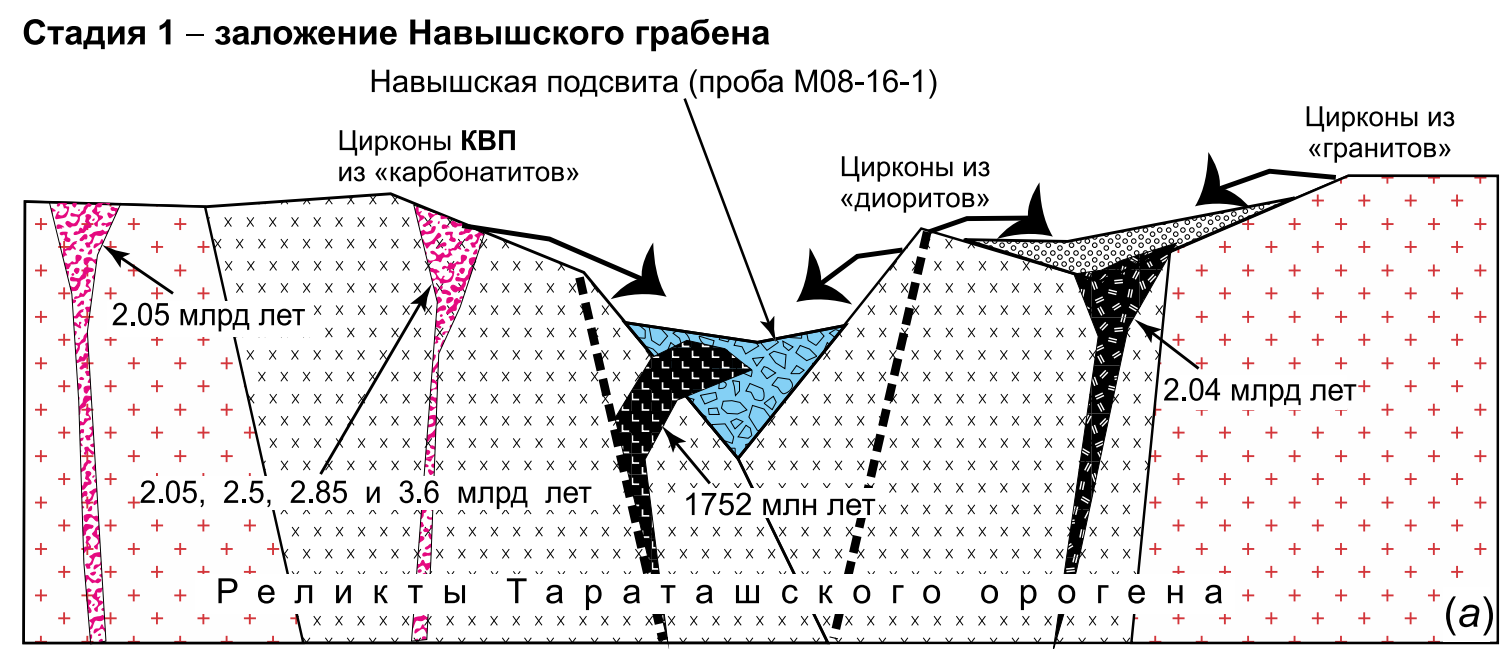

\section{Стадия 2 - расширение Навышского грабена и заложение Камско-Бельского авлакогена}

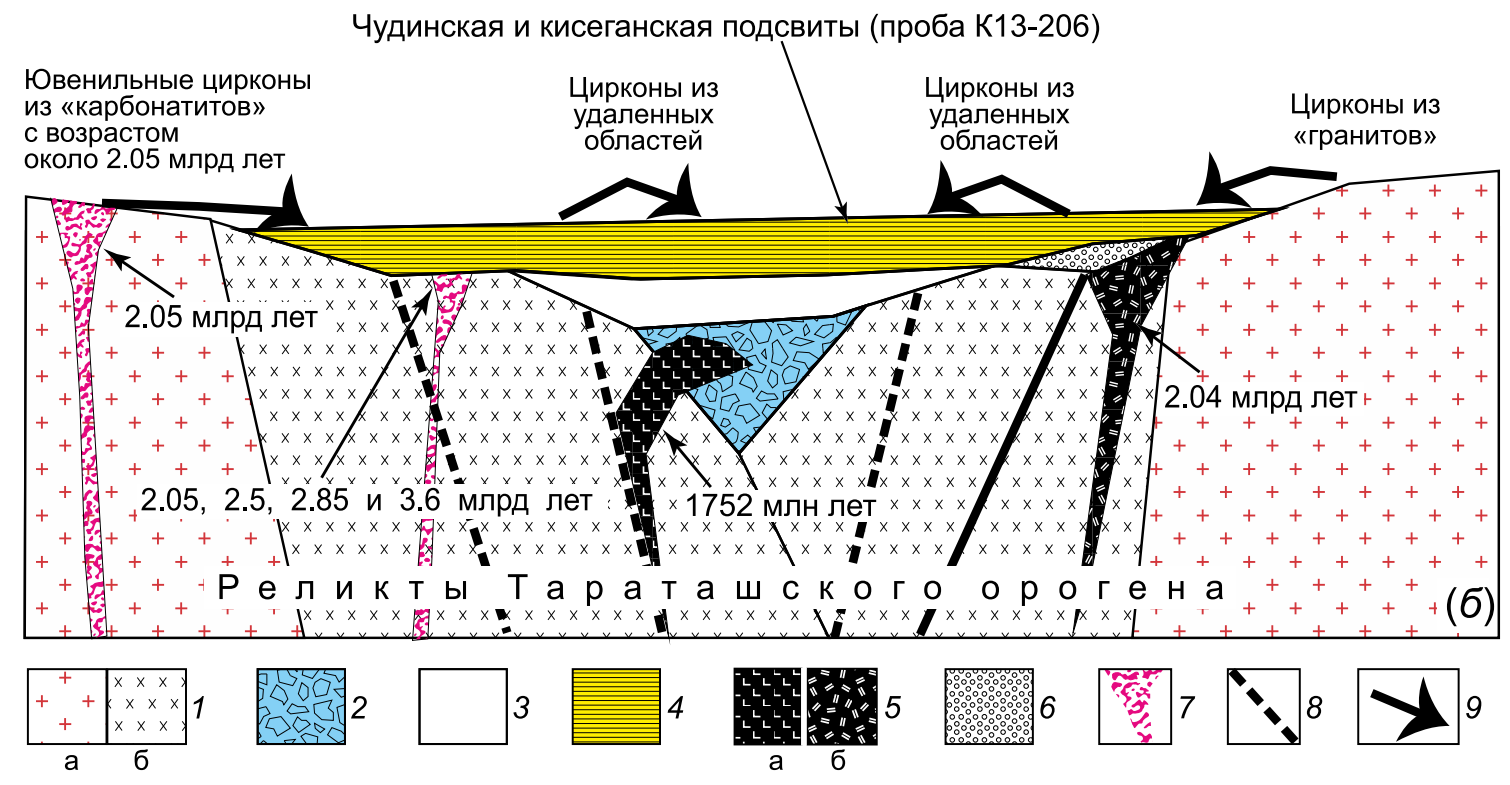

Рис. 17. Концептуальная внемасштабная схема формирования и заполнения Навышского грабена и начальных стадий образования Камско-Бельского авлакогена.

1 - блоки консолидированной коры протократона Волго-Уралия с реликтами комплексов Тараташского орогена: (а) - с нормальной (65-75 \% $\mathrm{SiO}_{2}$ в породах) и (б) - с пониженной (менее 65 \% $\mathrm{SiO}_{2}$ в породах) валовой кремнекислотностью пород; 2 навышская подсвита - базальные конгломераты (выполнение базальных уровней Навышского грабена); 3 - липовская подсвита - аллювиальные отложения; 4 - чудинская и кисеганская подсвиты - прибрежно-дельтовые гравелито-песчаные и углистоглинистые отложения; 5 - магматиты: а - субщелочные вулканиты айской свиты с возрастом 1752 млн лет, б - плутонические породы в тараташском комплексе с возрастом около 2.05 млрд лет; 6 - моласса раннепалеопротерозойских орогенов; 7 - реликты пород карбонатитового магматизма; 8 - разломы, ограничивающие на схеме $(a)$ Навышский грабен; 9 - перемещение эрозионных продуктов. КВП - цирконы группы КВП (крупные вишневые прозрачные, объяснения см. в тексте).

Fig. 17. A conventional scheme showing the formation and filling of the Navysh Graben and the initial stages of the formation of the Kama-Belaya aulacogene.

1 - consolidated crust blocks of the Volgo-Uralia protocraton with the relicts of the Taratash orogen's complexes: (a) with normal (65-75\% SiO 2 in the rocks) and (б) reduced (less than $65 \% \mathrm{SiO}_{2}$ in the rocks) total silicic acidity of the rocks; 2 - Navysh formation - basal conglomerates (basal levels of the Navysh Graben); 3 - Lipov formation - alluvial deposits; 4 - Chudin and Kisekan formation - coastaldelta gravel-sandy and carbonaceous-argillaceous deposits; 5 - magmatites: a - subalkaline volcanics of the Ai formation (1752 Ma), 6 plutonic rocks in the Taratash complex (about $2.05 \mathrm{Ga}$ ); 6 - molasses of Early Paleo-Proterozoic orogens; 7 - relics of carbonatite magmatic rocks; 8 - faults bordering the Navysh graben, see scheme $(a) ; 9$ - displacement of erosion products. КВП - large-size transparent cerise-colour zircons (see the explanations in the text). 
следовательность смены осадков от пролювиально-аллювиальных к пойменным и прибрежно-морским указывает на трансгрессивный характер смены осадконакопления в условиях конседиментационной рифтогенной впадины.

Первичным источником архейских цирконов (в том числе и с очень древним возрастом - более 3 млрд лет и модельным возрастом до 3.9 млрд лет), наиболее вероятно, были комплексы фундамента Волго-Уралии, в сложении которого участвовал мезоархейский и палеоархейский коровый материал. Генерация специфических «карбонатитовых» цирконов КВП может быть объяснена либо вовлечением древнего материала в магматический субстрат во время эпизодов карбонатитового магматизма на рубежах около 3.6, 2.85, 2.5 и 2.05 млрд лет, либо повторным плавлением без существенной контаминации на рубежах около 2.85, 2.5 и 2.0 млрд лет карбонатитового вещества, первично сгенерированного около рубежа 3.6 млрд лет. Карбонатитовые породы весьма редкие и слагают, как правило, малообъемные тела, существенно уступающие по размерам телам, сложенным гранитоидами и их эффузивными аналогами (источники «диоритовых», «гранитных» и «лейкогранитных» цирконов). Этим может быть объяснено доминирующее количество «гранитоидных» детритовых цирконов и подчиненное количество «карбонатитовых» детритовых цирконов в кластике. Соответственно чрезвычайно маловероятно, что разновозрастные, но однотипные по своим морфологическим (цвет и размер), Нf-изотопным и геохимическим (пониженным содержаниям РЗЭ) характеристикам цирконы группы КВП попали в пробу M08-16-1 из разных первичных источников за счет многократного рециклирования обломочного материала. Гораздо более вероятно, что «карбонатитовые» цирконы группы КВП происходят из единого первичного источника (который был локальным источником для детритовых цирконов, содержащихся в песчаниках пробы М08-16-1) и попали в пробу непосредственно за счет его размыва.

В пробе К13-206 обнаружены четыре «карбонатитовых» циркона с возрастом около 2.05 млрд лет и мантийным типом субстрата. Отметим, что по данным, приведенным в работах [Ronkin et al., 2012; Tevelev et al., 2015], цирконы из кристаллических пород, отобранных из разных блоков тараташского комплекса, показали возраст 2055 $45,2052 \pm 41$, $2020 \pm 17$ и 2044ะ4 млн лет (верхнее пересечение конкордии и дискордии), что свидетельствует об эпизоде тектономагматической активности, проявленной здесь в комплексе примерно около рубежа 2.04 млрд лет назад, идеально совпадающей с возрастом «карбонатитовых» цирконов. Однако до сих пор докембрийские карбонатитовые породы ни в тараташском комплексе, ни в юго-восточной части ВЕП не описаны и вопрос об источнике этих «карбонатитовых» цирконов - открытый, но имеет перспективу быть решенным по мере накопления данных о фундаменте.

Палеопротерозойские цирконы были массово генерированы в аккреционно-коллизионных палеопротерозойских орогенах, сутурировавших протократоны. Впоследствии верхние горизонты палеопротерозойских орогенов были эродированы, а продукты их разрушения перемешаны в разных пропорциях с продуктами разрушения протократонов и аккумулированы в палеопротерозойской молласе, которая представляла собой вторичный источник как палеопротерозойских, так и архейских цирконов.

В пробе К13-206 палеопротерозойские цирконы примерно в равных пропорциях представлены цирконами из «гранитов» и «диоритов», исключая вышеупомянутые «карбонатитовые» цирконы. Такой сигнал ожидаем при размыве молассы (синорогенного комплекса обломочных пород, сложенных продуктами разрушения этого орогена). Однако в пробе M08-16-1 все цирконы, кроме «карбонатитовых», классифицированы как цирконы, происходящие из «диоритов», т.е. как цирконы из гранитоидов с пониженной кремнекислотностью или их эффузивных аналогов. Ни один циркон не был классифицирован как «гранитный», хотя именно породы с нормальной/повышенной кремнекислотностью являются основным массовым генератором цирконов. Отсутствие в пробе М08-16-1 цирконов, родительскими породами которых были «граниты», свидетельствует о том, что ни гранитоидные массивы, ни осадочный комплекс, содержащий продукты их разрушения, не экспонировались (не обнажались) в пределах палеоводосборов во время накопления обломочных пород навышской подсвиты. Здесь нельзя не отметить, что в тараташском метаморфическом комплексе на современном эрозионном срезе гранитоиды нормальной и повышенной кремнекислотности широко распространены. Наряду с идентификацией «карбонатитового» массива как локального источника для пробы М08-16-1 это свидетельствует о том, что базальные уровни выполнения Навышского грабена (навышская подсвита) в месте отбора пробы М08-16-1 наиболее вероятно формировались за счет размыва очень ограниченных по площади палеоводосборов. В основном это были только комплексы, экспонированные в непосредственной близости от Навышского грабена - на его бортах.

На более поздних - завершающих - этапах заполнения Навышского грабена, когда формировалась чудинская подсвита (проба К13-206), уже началось общее обширное прогибание, приведшее впоследствии к формированию Камско-Бельского 
T.V. Romanyuk et al.: Paleotectonic and paleogeographic conditions for the accumulation of the Lower Riphean Ai Formation...

авлакогена. В это время в грабене начали аккумулироваться эрозионные продукты, попадавшие сюда с палеоводосборов более обширной площади. Размываемые молассовые отложения содержали перемешанный материал разрушения палеопротерозойских орогенов и архейских протократонов. Однако к этому времени значительные площади архейского фундамента Волго-Уралии, вероятно, были покрыты проточехлом и не дренировались, поэтому архейский детрит в пробе К13-206 представлен скуднее по сравнению с пробой М08-16-1 и по количеству, и по возрасту. Родительские породы архейских цирконов из пробы К13-206 более ювенильные по Hf признакам, а среди гранитоидных цирконов - в равной степени представлены цирконы из пород с пониженной и нормальной кремнекислотностью, в то время как в пробе М08-16-1 только с пониженной.

\section{0. ЗАКЛЮЧЕНИЕ}

В статье приведены результаты комплексного (метод «TerraneChrone ${ }^{\circledR}$ ) ) изучения детритовых цирконов из навышских (проба М08-16-1) и чудинских (проба К13-206) песчаников нижнерифейской айской свиты БП. Сопоставление U/Pb-изотопных возрастных характеристик цирконов показывает, в целом, их схожесть: в обеих пробах преобладают палеопротерозойские цирконы, при этом доминирующие пики фактически совпали - 2063 и 2055 млн лет. Архей представлен немногочисленными зернами, но в пробе М08-16-1 архей все же более представителен и, в частности, присутствуют три очень древних циркона с возрастом более 3 млрд лет $-3060 \pm 28,3241 \pm 69$ и $3625 \pm 53$ млн лет.

Зафиксированные в цирконах отношения $\mathrm{Th} / \mathrm{U}>0.1$ (за исключением одного зерна) позволяют классифицировать их как «магматические». На классификационной диаграмме «U/Yb vs Hf», отделяющей цирконы из океанических базальтов от цирконов из пород континентального генезиса, за исключением одной фигуративной точки, все располагаются в поле цирконов «континентального происхождения». Это свидетельствует о малой роли комплексов океанического или окраинно-морского генезиса среди первичных источников цирконов и лучше согласуется с внутриконтинентальным, а не окраинно-континентальным расположением рифейского бассейна, базальные уровни которого выполнены айской свитой.

При схожести U/Pb-изотопных возрастных параметров по Нf-изотопным признакам и содержаниям элементов-примесей в детритовых цирконах в изученных пробах зафиксированы следующие наиболее важные различия, свидетельствующие о том, что первичными источниками цирконов для двух проб были существенно различные по геодинамической природе кристаллические комплексы.

(1) В обеих изученных пробах обнаружены специфические по содержаниям элементов-примесей (низкие содержания РЗЭ - <300 г/т и Lu 3 г/T<Lu<33 г/т вместе с умеренными содержаниями Hf>0.62 \%) цирконы, которые классифицированы как цирконы, произошедшие из карбонатитовых пород. Однако по Нf-изотопным признакам магмогенерирующий субстрат, из которого выплавились породы, материнские по отношению к этим цирконам, был различным. В пробе К13-206 зафиксированы четыре ювенильных «карбонатитовых» циркона с возрастом около 2.05 млрд лет и модельным возрастом субстрата $\mathrm{T}_{\mathrm{DM}}^{\mathrm{C}}$ 2.2-2.9 млрд лет, а в М08-16-1 - 11 «карбонатитовых» цирконов с возрастом около 3.6, 2.85, 2.5 и 2.0 млрд лет. Среди последних шесть схожи по внешнему виду - крупные вишневые прозрачные (группа КВП) - и образуют тренд на диаграмме $\varepsilon_{\mathrm{Hf}}$ с очень древним модельным возрастом $\mathrm{T}_{\mathrm{DM}}^{\mathrm{C}}-3.2-3.9$ млрд лет. «Карбонатитовые» цирконы с возрастом 2.85 и 3.6 млрд лет мы интерпретируем как косвенные следы эпизодов карбонатитового магматизма, хотя сами комплексы, возможно, не сохранились, так как карбонатитовые комплексы с таким возрастом в настоящее время не известны.

(2) В цирконах из пробы М08-16-1 зафиксированы систематически более низкие содержания Hf по сравнению с пробой К13-206, что вместе с пониженными содержаниями РЗЭ позволяет классифицировать родительские породы цирконов как «диориты» (гранитоиды и их эффузивные аналоги пониженной кремнекислотности) и вышеупомянутые «карбонатиты». В пробе К13-206, помимо «карбонатитов», в качестве родительских пород цирконов в равных количествах прогнозируются «диориты» и «граниты» (гранитоиды и их эффузивные аналоги нормальной кремнекислотности). Таким образом, в пробе М08-16-1 по сравнению с пробой К13-206, бо́льшую роль играют цирконы, произошедшие из менее кремнекислотных и/или щелочных/сиенитовых родительских пород.

(3) В пробе К13-206 архейские цирконы имеют положительные или близнулевые значения $\varepsilon_{\mathrm{Hf}}$, что не оставляет сомнений в ювенильном происхождении субстрата родительских пород этих цирконов; в пробе М08-16-1 представлены как ювенильные архейские цирконы, так и архейские цирконы с существенно отрицательными значениями $\varepsilon_{\mathrm{Hf}}$, что свидетельствует об участии в субстрате их родительских пород изотопно-зрелого мезоархейского и палеоархейского материала.

Выявленные особенности возрастных, Нf-изотопных и геохимических характеристик цирконов 
из песчаников двух стратиграфических уровней айской свиты могут быть объяснены в рамках модели формирования этой свиты в рифтовой структуре - в Навышском грабене - предшественнике КамскоБельского авлакогена в пределах суперконтинента Колумбия. На самой начальной стадии рифтогенеза в Навышском грабене формировалась толща грубообломочных пород (навышская подсвита, охарактеризованная пробой М08-16-1). Эти породы формировались за счет накопления продуктов размыва очень ограниченных по площади палеоводосборов в основном это были только комплексы непосредственно из бортов Навышского грабена, в том числе и комплекс, содержащий специфические «карбонатитовые» цирконы КВП с участием древнейшего палеоархейского корового материала. Первичными источниками цирконов в пробе М08-16-1 были только расположенные поблизости карбонатиты и гранитоидные комплексы пониженной кремнекислотности. В завершающую стадию рифтогенеза, уже на начальных стадиях развития Камско-Бельского авлакогена, в грабен стали попадать эрозионные продукты с палеоводосборов более обширной площади, где были распространены первичные источники кластики, представленные в равной степени гранитоидами пониженной и нормальной кремнекислотности. В чудинскую подсвиту также попадали «карбонатитовые» ювенильные цирконы с возрас- том около 2.05 млрд лет (в пробе К13-206 установлено четыре таких зерна). Однако к этому времени значительные площади развития архейских кристаллических комплексов Волго-Уралии, вероятно, были перекрыты проточехлом и не дренировались, поэтому архейский детрит в пробе К13-206 представлен скуднее по сравнению с пробой М08-16-1 по количеству цирконов, и по значениям возраста.

\section{1. БЛАГОДАРНОСТИ}

Статья подготовлена в соответствии с планами фундаментальных исследований ГИН и ИГ УНЦ PAH. The analytical data were obtained using instrumentation funded by DEST Systemic Infrastructure Grants, ARC LIEF, NCRIS/AuScope, industry partners and Macquarie University and support of grant ARC FT110100685 (E.A Belousova). This is contribution 1080 from the ARC Centre of Excellence for Core to Crust Fluid Systems (http://www.ccfs.mq.edu.au) and 1207 in the GEMOC Key Centre (http://www.gemoc. mq.edu.au). Обработка данных проведена за счет средств РНФ (проект № 14-27-00058), материалы по строению Урала и ВЕП собраны в соответствии с задачами гранта 14.Z50.31.0017 МOH РФ, подготовка публикации проведена при поддержке РФФИ (проект № 16-05-00259).

\section{2. ЛИТЕРАTУРA / REFERENCES}

Andersen T., 2005. Detrital zircons as tracers of sedimentary provenance: limiting conditions from statistics and numerical simulation. Chemical Geology 216 (3-4), 249-270. https://doi.org/10.1016/j.chemgeo.2004.11.013.

Aranovich L.Y., Bortnikov N.S., Zinger T.F., Borisovskiy S.E., Matrenichev V.A., Pertsev A.N., Sharkov E.V., Skolotnev S.G., 2017. Morphology and impurity elements of zircon in the oceanic lithosphere at the Mid-Atlantic ridge axial zone $\left(6^{\circ}-13^{\circ} \mathrm{N}\right)$ : Evidence of specifics of magmatic crystallization and postmagmatic transformations. Petrology 25 (4), 339-364. https://doi.org/10.1134/S0869591117040026.

Belousova E.A., Gonzalez J.M., Graham J.I., Griffin W.L., O'Reilly S.Y., Pearson N.J., Martin L., Craven S., Talavera C., 2015. The enigma of crustal zircons in upper-mantle rocks: Clues from the Tumut ophiolite, southeast Australia. Geology 43 (2), 119-122. https://doi.org/10.1130/G36231.1.

Belousova E., Griffin W.L., O'Reilly S.Y., Fisher N.L., 2002. Igneous zircon: trace element composition as an indicator of source rock type. Contributions to Mineralogy and Petrology 143 (5), 602-622. https://doi.org/10.1007/s00410002-0364-7.

Belousova E.A., Griffin W.L., O'Reilly S.Y., 2006. Zircon crystal morphology, trace element signatures and Hf isotope composition as a tool for petrogenetic modeling: examples from eastern Australian granitoids. Journal of Petrology 47 (2), 329-353. https://doi.org/10.1093/petrology/egi077.

Belousova E.A., Kostitsyn Y.A., Griffin W.L., Begg G.C., O'Reilly S.Y., Pearson N.J., 2010. The growth of the continental crust: constraints from zircon Hf-isotope data. Lithos 119 (3-4), 457-466. https://doi.org/10.1016/j.lithos.2010. 07.024 .

Bibikova E.V., Bogdanova S.V., Postnikov A.V., Popova L.P., Kirnozova T.I., Fugzan M.M., Glushchenko V.V., 2009. SarmatiaVolgo-Uralia junction zone: Isotopic-geochronologic characteristic of supracrustal rocks and granitoids. Stratigraphy and Geological Correlation 17 (6), 561-573. https://doi.org/10.1134/S086959380906001X.

Bogdanova S.V., Belousova E.A., De Waele B., Postnikov A.V., 2013. Zircon from Mesoarchean enderbites of Volgo-Uralia: $\mathrm{U}-\mathrm{Pb}$ age, REE, Hf and O-isotope compositions. Mineralogical Magazine 77 (5), 727. https://doi.org/10.1180/ minmag.2013.077.5.2.

Bogdanova S.V., Bingen B., Gorbatschev R., Kheraskova T.N., Kozlov V.I., Puchkov V.N., Volozh Yu.A., 2008. The East European Craton (Baltica) before and during the assembly of Rodinia. Precambrian Research 160 (1-2), 23-45. https://doi.org/10.1016/j.precamres.2007.04.024. 
Bogdanova S.V., De Waele B., Bibikova E.V., Belousova E.A., Postnikov A.V., Fedotova A.A., Popova L.P., 2010. Volgo-Uralia: the first U-Pb, Lu-Hf and Sm-Nd isotopic evidence of preserved Paleoarchean crust. American Journal of Science 310 (10), 1345-1383. https://doi.org/10.2475/10.2010.06.

Bouvier A., Vervoort J.D., Patchett P.J., 2008. The Lu-Hf and Sm-Nd isotopic composition of CHUR: constraints from unequilibrated chondrites and implications for the bulk composition of terrestrial planets. Earth and Planetary Science Letters 273 (1-2), 48-57. https://doi.org/10.1016/j.epsl.2008.06.010.

Claiborne L.E., Miller C.F., Walker B.A., Wooden J.L., Mazdab F.K., Bea F., 2006. Tracking magmatic processes through $\mathrm{Zr} / \mathrm{Hf}$ ratios in rocks and $\mathrm{Hf}$ and Ti zoning in zircons: An example from the Spirit Mountain batholith, Nevada. Mineralogical Magazine 70 (5), 517-543. https://doi.org/10.1180/0026461067050348.

Corfu F., Bayanova T., Shchiptsov V., Frantz N., 2011. U-Pb ID-TIMS age of the Tiksheozero carbonatite: expression of 2.0 Ga alkaline magmatism in Karelia, Russia. Open Geosciences 3 (3), 302-308. https://doi.org/10.2478/s13533011-0029-z.

Corfu F., Hanchar J.M., Hoskin P.-W.O., Kinny P., 2003. Atlas of zircon textures. Reviews in Mineralogy and Geochemistry 53 (1), 469-500. https://doi.org/10.2113/0530469.

Ernst R.E., Bell K., 2009. Large igneous provinces (LIPs) and carbonatites. Mineralogy and Petrology 98 (1-4), 55-76. https://doi.org/10.1007/s00710-009-0074-1.

Ernst R.E., Hamilton M.A., Söderlund U., Hanes J.A., Gladkochub D.P., Okrugin A.V., Kolotilina T., Mekhonoshin A.S., Bleeker W., LeCheminant A.N., Buchan K.L., Chamberlain K.R., Didenko A.N., 2016. Long-lived connection between southern Siberia and northern Laurentia in the Proterozoic. Nature Geoscience 9 (6), 464-469. https://doi.org/10.1038/ NGEO2700.

Evans D.A.D., Mitchell R.N., 2011. Assembly and breakup of the core of Paleoproterozoic-Mesoproterozoic supercontinent Nuna. Geology 39 (5), 443-446. https://doi.org/10.1130/G31654.1.

Fedo C.M., Sircombe K.N., Rainbird R.H., 2003. Detrital zircon analysis of the sedimentary record. Reviews in Mineralogy and Geochemistry 53, 277-303. https://doi.org/10.2113/0530277.

Fedotova A.A., Bibikova E.V., Simakin S.G., 2008. Ion-microprobe zircon geochemistry as an indicator of mineral genesis during geochronological studies. Geochemistry International 46 (9), 912-927. https://doi.org/10.1134/S001670 290809005X.

Fershtater G.B., Krasnobaev A.A., Bea F., Montero P., 2012. The geochemistry of zircon from the Urals igneous and metamorphic rocks. Litosfera (Lithosphere) (4), 13-29 (in Russian) [Ферштатер Г.Б., Краснобаев А.А., Беа Ф., Монтеро П. Геохимия циркона из магматических и метаморфических пород Урала // Литосфера. 2012. № 4. C. 13-29].

Fornelli A., Langone A., Micheletti F., Pascazio A., Piccarreta G., 2014. The role of trace element partitioning between garnet, zircon and orthopyroxene on the interpretation of zircon U-Pb ages: an example from high-grade basement in Calabria (Southern Italy). International Journal of Earth Sciences 103 (2), 487-507. https://doi.org/ 10.1007/s00531-013-0971-8.

Gorozhanin V.M., Puchkov V.N., Gorozhanina E.N., Sergeeva N.D., Romanyuk T.V., Kuznetsov N.B., 2014. Navysh grabenrift at the Southern Urals as a fragment of the Early Riphean aulacogen. Doklady Earth Sciences 458 (1), 1052 1057. https://doi.org/10.1134/S1028334X1409013X.

Griffin W.L., Belousova E.A., Shee S.R., Pearson N.J., O'Reilly S.Y., 2004. Archean crustal evolution in the northern Yilgarn Craton: U-Pb and Hf-isotope evidence from detrital zircons. Precambrian Research 131 (3-4), 231-282. https:// doi.org/10.1016/j.precamres.2003.12.011.

Griffin W.L., Belousova E.A., Walters S.G., O'Reilly S.Y., 2006. Archean and Proterozoic crustal evolution in the Eastern Succession of the Mt Isa district, Australia: U-Pb and Hf-isotope studies of detrital zircons. Australian Journal of Earth Sciences 53 (1), 125-149. https://doi.org/10.1080/08120090500434591.

Griffin W.L., Pearson N.J., Belousova E., Jackson S.E., O'Reilly S.Y., van Achterberg E., Shee S.R., 2000. The Hf isotope composition of cratonic mantle: LAM-MC-ICPMS analysis of zircon megacrysts in kimberlites. Geochimica et Cosmochimica Acta 64 (1), 133-147. https://doi.org/10.1016/S0016-7037(99)00343-9.

Grimes C.B., John B.E., Kelemen P.B., Mazdab F.K., Wooden J.L., Cheadle M.J., Hanghoj K., Schwartz J.J., 2007. Trace element chemistry of zircons from oceanic crust: A method for distinguishing detrital zircon provenance. Geology 35 (7), 643-646. https://doi.org/10.1130/G23603A.1.

Grimes C.B., Wooden J.L., Cheadle M.J., John B.E., 2015. "Fingerprinting" tectono-magmatic provenance using trace elements in igneous zircon. Contributions to Mineralogy and Petrology 170 (5-6), Article 46. https://doi.org/ 10.1007/s00410-015-1199-3.

Halden N.M., Hawthorne F.C., Campbell J.L., Teesdale W.J., Maxwell J.A. Higuchi D., 1993. Chemical characterization of oscillatory zoning and overgrowths in zircon using $3 \mathrm{MeV} \mu$-PIXE. Canadian Mineralogist 31 (3), 637-647.

Harrison T.M., Watson E.B., 1983. Kinetics of zircon dissolution and zirconium diffusion in granitic melts of variable water content. Contributions to Mineralogy and Petrology 84 (1), 66-72. https://doi.org/10.1007/BF01132331.

Harrison T.M., Watson E.B., Aikman A.B., 2007. Temperature spectra of zircon crystallization in plutonic rocks. Geology 35 (7), 635-638. https://doi.org/10.1130/G23505A.1. 
Hinton R.W., Upton B.G.J., 1991. The chemistry of zircon: Variations within and between large crystals from syenite and alkali basalt xenoliths. Geochimica et Cosmochimica Acta 55 (11), 3287-3302. https://doi.org/10.1016/00167037(91)90489-R.

Hoskin P.O., Ireland T.R., 2000. Rare earth element chemistry of zircon and its use as a provenance indicator. Geology 28 (7), 627-630. https://doi.org/10.1130/0091-7613(2000)28<627:REECOZ>2.0.CO;2.

Hoskin P.W., Schaltegger U., 2003. The composition of zircon and igneous and metamorphic petrogenesis. Reviews in Mineralogy and Geochemistry 53 (1), 27-62. https://doi.org/10.2113/0530027.

Jackson S.E., Pearson N.J., Griffin W.L., Belousova E.A., 2004. The application of laser ablation-inductively coupled plasma-mass spectrometry to in situ U-Pb zircon geochronology. Chemical Geology 211 (1-2), 47-69. https://doi.org/ 10.1016/j.chemgeo.2004.06.017.

Jones A.P., Genge M., Carmody L., 2013. Carbonate melts and carbonatites. Reviews in Mineralogy \& Geochemistry 75 (1), 289-322. https://doi.org/10.2138/rmg.2013.75.10.

Kaczmarek M.A., Müntener O., Rubatto D., 2008. Trace element chemistry and U-Pb dating of zircons from oceanic gabbros and their relationship with whole rock composition (Lanzo, Italian Alps). Contributions to Mineralogy and Petrology 155 (3), 295-312. https://doi.org/10.1007/s00410-007-0243-3.

Keller B.M., Chumakov N.M. (Eds.), 1983. Stratotype of the Riphean. Stratigraphy. Geochronology. Nauka, Moscow, 184 p. (in Russian) [Стратотип рифея. Стратиграфия. Геохронология / Ред. Б.М. Келлер, Н.М. Чумаков. М.: Наука, 1983. 184 с.].

Khotylev A.O., Tevelev A.V., 2017. Geochemical features of volcanics of the Early Riphean Navysh complex (Southern Urals). Bulletin of the Moscow University. Series 4: Geology (6), 28-34 (in Russian) [Хотылев А.О., Тевелев А.В. Геохимические особенности вулканитов раннерифейского навышского комплекса (Южный Урал) // Вестник Московского университета. Серия 4: Геология. 2017. № 6. С. 28-34].

Kirkland C.L., Smithies R.H., Taylor R.J.M., Evans N., McDonald B., 2015. Zircon Th/U ratios in magmatic environs. Lithos 212-215, 397-414. https://doi.org/10.1016/j.lithos.2014.11.021.

Kostitsyn Y.A., Belousova E.A., Silant'ev S.A., Bortnikov N.S., Anosova M.O., 2015. Modern problems of geochemical and $\mathrm{U}-\mathrm{Pb}$ geochronological studies of zircon in oceanic rocks. Geochemistry International 53 (9), 759-785. https:// doi.org/10.1134/S0016702915090025.

Krasnobaev A.A., Bibikova E.V., Ronkin Yu.L., Kozlov V.I., 1992. The geochronology of the volcanic rocks of the Ai formation and the isotope age of the lower boundary of the Riphean. Izvestiya AN, Seriya Geologicheskaya (6), 25-40 (in Russian) [Краснобаев А.А., Бибикова Е.В., Ронкин Ю.Л., Козлов В.И. Геохронология вулканитов айской свиты и изотопный возраст нижней границы рифея // Известия AH, серия геологическая. 1992. № 6. С. 25-40].

Krasnobaev A.A., Puchkov V.N., Kozlov V.I., Sergeeva N.D., Busharina S.V., Lepekhina E.N., 2013. Zirconology of Navysh volcanic rocks of the Ai Suite and the problem of the age of the Lower Riphean boundary in the Southern Urals. Doklady Earth Sciences 448 (2), 185-190. https://doi.org/10.1134/S1028334X13020050.

Kuznetsov N.B. Maslov A.V., Belousova E.A., Romanyuk T.V., Krupenin M.T., Gorozhanin V.M., Gorozhanina E.N., Seregina E.S., Tselmovich V.A., 2013. The first U-Pb (LA-ICP-MS) isotope data of detrital zircons from the basal levels of the Riphean stratotype. Doklady Earth Sciences 451 (1), 724-728. https://doi.org/10.1134/S1028334X1307026X.

Kuznetsov N.B., 2009. Protouralides-Tymanide Complexes and the Late Precambrian - Early Paleozoic Evolution of the Eastern and Northeastern Frame of the East European Platforms. Brief PhD Thesis (Doctor of Geology and Mineralogy). IPE RAS, Moscow, 51 p. (in Russian) [Кузнецов Н.Б. Комплексы протоуралид-тиманид и позднедокембрийско-раннепалеозойская эволюция восточного и северо-восточного обрамления Восточно-Европейской платформы: Автореф. дис. ... докт. геол.-мин. наук. М.: ИФЗ РАН, 2009. 51 с.].

Kuznetsov N.B., Belousova E.A., Degtyarev K.E., Pyzhova E.S., Maslov A.V., Gorozhanin V.M., Gorozhanina E.N., Romanyuk T.V., 2016. The first results of the U/Pb dating of detrital zircons from the Later Ordovician sandstones of the Bashkir Uplifts (the Southern Urals). Doklady Earth Sciences 467 (2), 325-330. https://doi.org/10.1134/S1028334X16 040103.

Kuznetsov N.B., Belousova E.A., Romanyuk T.V., Degtyarev K.E., Maslov A.V., Gorozhanin V.M., Gorozhanina E.N., Pyzhova E.S., 2017. The first results of $\mathrm{U} / \mathrm{Pb}$ dating detrital zircons from sandstones of zigalga Formation (Middle Riphean, the South Urals. Doklady Earth Sciences 475 (2), 863-867. https://doi.org/10.1134/S1028334X17080244.

Kuznetsov N.B., Meert J.G., Romanyuk T.V., 2014a. Ages of detrital zircons (U/Pb, LA-ICP-MS) from the Latest Neoproterozoic - Middle Cambrian(?) Asha Group and Early Devonian Takaty Formation, the Southwestern Urals: A test of an Australia-Baltica connection within Rodinia. Precambrian Research 244, 288-305. https://doi.org/10.1016/ j.precamres.2013.09.011.

Kuznetsov N.B., Romanyuk T.V., Shatsillo A.V., Orlov S.Yu., Gorozhanin V.M., Gorozhanina E.N., Seregina E.S., Ivanova N.S., Meeret J., 2014b. The first results of the U/Pb-dating (LA-ICP-MS) of the detrital zircons from sandstones of the Upper Emsian Takata Formation, the Western Urals (with a problem of an ultimate sources of the Uralian diamond placers). Doklady Earth Sciences 455 (2), 370-375. https://doi.org/10.1134/S1028334X14040084.

Linnemann U., Ouzegane K., Drareni A., Hofmann M., Becker S., Gärtner A., Sagawe A., 2011. Sands of West Gondwana: an archive of secular magmatism and plate interactions - a case study from the Cambro-Ordovician section of the Tassili Ouan Ahaggar (Algerian Sahara) using U-Pb-LA-ICP-MS detrital zircon ages. Lithos 123 (1-4), 188-203. https://doi.org/10.1016/j.lithos.2011.01.010. 
Liu J., Liu F., Ding Z., Yang H., Liu C., Liu P., Xiao L., Zhao L., Geng J., 2013. U-Pb dating and Hf isotope study of detrital zircons from the Zhifu Group, Jiaobei Terrane, North China Craton: Provenance and implications for Precambrian crustal growth and recycling. Precambrian Research 235, 230-250. https://doi.org/10.1016/j.precamres.2013. 06.014 .

Ludwig K.R., 2001. Users Manual for Isoplot/Ex rev. 2.49. A Geochronological Toolkit for Microsoft Excel. Berkeley Geochronology Center Special Publication, vol. 1a, p. 1-55.

Maslov A.V., 2004. Riphean and Vendian sedimentary sequences of the Timanides and Uralides, the eastern periphery of the East European Craton. In: D.G. Gee, V. Pease (Eds.), The Neoproterozoic Timanide orogen of Eastern Baltica. Geological Society, London, Memoirs, vol. 30, p. 19-35. https://doi.org/10.1144/GSL.MEM.2004.030.01.03.

McDonough W.F., Sun S.S., 1995. The composition of the Earth. Chemical Geology 120 (3-4), 223-253. https://doi.org/ 10.1016/0009-2541(94)00140-4.

Meert J.G., 2002. Paleomagnetic evidence for a Paleo-Mesoproterozoic supercontinent Columbia. Gondwana Research 5 (1), 207-215. https://doi.org/10.1016/S1342-937X(05)70904-7.

Mints M.V., Suleimanov A.K., Babayants P.S., Belousova E.A., Blokh Yu.I., Bogina M.M., Bush W.A., Dokukina K.A., Zamozhniaya N.G., Zlobin V.L., Kaulina T.V., Konilov A.N., Mikhailov V.O., Natapov L.M., Piip V.B., Stupak V.M., Tikhotsky S.A., Trusov A.A., Philippova I.B., Shur D.Yu., 2010. Deep Structure, Evolution and Mineral Deposits of the Early Precambrian Basement of the East European Platform: An Interpretation of the Data from 1-EU Geotraverse, the 4B and TATSEIS Profiles. GEOKART, GEOS, Moscow, vol. 1, 408 p.; vol. 2, 400 p. (in Russian) [Минц М.В., Сулейманов А.К., Бабаянц П.С., Белоусова Е.А., Блох Ю.И., Богина М.М., Буш В.А., Докукина К.А., Заможняя Н.Г., Злобин В.Л., Каулина Т.В., Конилов А.Н., Михайлов В.О., Натапов Л.М., Пийп В.Б., Ступак В.М., Тихоцкий С.А., Трусов А.А., Филиппова И.Б., Шур Д.Ю. Глубинное строение, эволюция и полезные ископаемые раннедокембрийского фундамента Восточно-Европейской платформы: Интерпретация материалов по опорному профилю 1-ЕВ, профилям 4В и ТАТСЕЙС. М.: ГЕОКАРТ; ГЕОС, 2010. Т. 1, 408 с., Т. 2, 400 с.].

Mitchell R.H., 2005. Carbonatites and carbonatites and carbonatites. The Canadian Mineralogist 43 (6), 2049-2068. https://doi.org/10.2113/gscanmin.43.6.2049.

Pesonen L.J., Elming S.-A., Mertanen S., Pisarevsky S., D'Agrella-Filho M.S., Meert J.G., Schmidt P.W., Abrahamsen N., Bylund G., 2003. Palaeomagnetic configuration of continents during the Proterozoic. Tectonophysics 375 (1-4), 289-324. https://doi.org/10.1016/S0040-1951(03)00343-3.

Pisarevsky S.A., Elming S.-A., Pesonen L.J., Li, Z.-X., 2014. Mesoproterozoic paleogeography: Supercontinent and beyond. Precambrian Research 244, 207-225. https://doi.org/10.1016/j.precamres.2013.05.014.

Poller U., Huth J., Hoppe P., Williams I.S., 2001. REE, U, Th, and Hf distribution in zircon from Western Carpathian Variscian granitoids: a combined cathodeluminescence and ion microprobe study. American Journal of Science 301 (10), 858-867. https://doi.org/10.2475/ajs.301.10.858.

Puchkov V.N., 2010. Geology of the Urals and the Ural Region. DesignPoligraphService, Ufa, 280 p. (in Russian) [Пучков В.Н. Геология Урала и Приуралья. Уфа: ДизайнПолиграфСервис, 2010. 280 с.].

Roger J.W., Santosh M., 2002. Configuration of Columbia, a Mesoproterozoic supercontinent. Gondwana Research 5 (1), 5-22. https://doi.org/10.1016/S1342-937X(05)70883-2.

Romanyuk T.V., Kuznetsov N.B., Maslov A.V., Belousova E.A., Krupenin M.T., Ronkin Yu.L., Gorozhanin V.M., Gorozhanina E.N., 2014. Geochemical and Lu/Hf isotopic (LA-ICP-MS) signature of detrital zircons from sandstones of the basal levels of the Riphean stratotype. Doklady Earth Sciences 459 (1), 1356-1360. https://doi.org/10.1134/S1028334 X14110257.

Romanyuk T.V., Kuznetsov N.B., Maslov A.V., Belousova E.A., Ronkin Yu.L., Goroganin V.M., Goroganina E.N., 2013. Geochemical and Lu-Hf (LA-ICP-MS) systematic of detrital zircons from lower neoproterozoic Lemeza Sandstones, Southern Urals. Doklady Earth Sciences 453 (2), 1200-1204. https://doi.org/10.1134/S1028334X13120222.

Ronkin Y.L., Sindern S., Lepikhina O.P., 2012. Isotope geology of the oldest Southern Urals formations. Litosfera (Lithosphere) (5), 50-76 (in Russian) [Ронкин Ю.Л., Синдер С., Лепихина О.П. Изотопная геология древнейших образований Южного Урала // Литосфера. 2012. № 5. С. 50-76].

Rubatto D., 2002. Zircon trace element geochemistry: partitioning with garnet and the link between U-Pb ages and metamorphism. Chemical Geology 184 (1-2), 123-138. https://doi.org/10.1016/S0009-2541(01)00355-2.

Rubatto D., Hermann J., 2007. Experimental zircon/melt and zircon/garnet trace element partitioning and implication for the geochronology of crustal rocks. Chemical Geology 241 (1-2), 38-61. https://doi.org/10.1016/j.chemgeo. 2007.01.027.

Rukhlov A.S., Bell K. Amelin Y., 2015. Carbonatites, isotopes and evolution of the subcontinental mantle: an overview. In: G.J. Simandl, M. Neetz (Eds.), Symposium on strategic and critical materials proceedings (November 13-14, 2015, Victoria, British Columbia). British Columbia Ministry of Energy and Mines, British Columbia Geological Survey Paper 2015-3, p. 39-64.

Savva E.V., Belyatsky B.V., Antonov A.V., 2010. Carbonatitic zircon. Acta Mineralogica-Petrographica, Abstract series 6, 576.

Scherer E., Münker C., Mezger K., 2001. Calibration of the Lutetium-Hafnium clock. Science 293 (5530), 683-687. https://doi.org/10.1126/science.1061372.

Semikhatov M.A. (Ed.), 1989. Lower Riphean of the Southern Urals. Nauka, Moscow, 208 p. (in Russian) [Нижний рифей Южного Урала / Ред. М.А. Семихатов. М.: Наука, 1989. 208 с.]. 
Semikhatov M.A., Kuznetsov A.B., Maslov A.V., Gorokhov I.M., Ovchinnikova G.V., 2009. Stratotype of the Lower Riphean, the Burzyan Group of the Southern Urals: Lithostratigraphy, paleontology, geochronology, Sr-and C-isotopic characteristics of its carbonate rocks. Stratigraphy and Geological Correlation 17 (6), 574-601. https://doi.org/ 10.1134/S0869593809060021.

Sklyarov E.V., Fedorovsky V.S., Kotov A.B., Lavrenchuk A.V., Mazukabzov A.M., Levitsky V.I., Sal'nikova E.B., Starikova A.E., Yakovleva S.Z., Anisimova I.V., Fedoseenko A.M., 2009. Carbonatites in collisional settings and pseudo-carbonatites of the Early Paleozoic Ol'khon collisional system. Russian Geology and Geophysics 50 (12), 1091-1106. https:// doi.org/10.1016/j.rgg.2009.11.008.

Sokolov B.S., Zhamoida A.I. (Eds.), 2002. General Stratigraphic Scale. Resolution of the MSC and Its Standing Commissions. Issue 33. VSEGEI, St. Petersburg, 51 p. (in Russian) [Общая стратиграфическая шкала. Постановление МСК и его постоянных комиссий. Вып. 33 / Ред. Б.С. Соколов, А.И. Жамойда СПб.: ВСЕГЕИ, 2002. 51 с.].

Stratigraphic Schemes of the Urals (Precambrian, and Paleozoic), 1993. Interdepartmental Stratigraphic Committee of Russia, Ekaterinburg, 151 diagrams (in Russian) [Стратиграфические схемы Урала (докембрий, палеозой). Екатеринбург: Межведомственный стратиграфический комитет России, 1993. 151 схема.].

Teipel U., Eichhorn R., Loth G., Rohrmuller J., Holl R., Kennedy A., 2004. U-Pb SHRIMP and Nd isotopic data from the western Bohemian Massif (Bayerischer Wald, Germany): implications for Upper Vendian and Lower Ordovician magmatism. International Journal of Earth Sciences 93 (5), 782-801. https://doi.org/10.1007/s00531-0040419-2.

Terentiev R.A., Savko K.A., Santosh M., 2016. Paleoproterozoic crustal evolution in the East Sarmatian Orogen: Petrology, geochemistry, $\mathrm{Sr}-\mathrm{Nd}$ isotopes and zircon $\mathrm{U}-\mathrm{Pb}$ geochronology of andesites from the Voronezh massif, Western Russia. Lithos 246-247, 61-80. https://doi.org/10.1016/j.lithos.2015.12.025.

Tevelev A.V., Kosheleva I.A., Khotylev A.O., Tevelev A.V., Prudnikov I.A., 2014. Peculiarities of the structure and evolution of the Riphean Ai volcanic complex, South Urals. Moscow University Geology Bulletin 69 (5), 289-298. https:// doi.org/10.3103/S0145875214050111.

Tevelev A.V., Kosheleva I.A., Tevelev A.V., Khotylev A.O., Moseichuk V.M., Petrov V.I., 2015. New data on the isotope ages of the Taratash and Aleksandrovka metamorphic complexes. Moscow University Geology Bulletin 70 (1), 24-40. https://doi.org/10.3103/S0145875215010081.

Tevelev A.V., Mosejchuk V.M., Tevelev A.V., Shkursky B.B., 2017. The zircon-age distribution in metamorphic rocks of the Taratash block, Southern Urals (an initial provenance signal). Moscow University Geology Bulletin 72 (5), 314-319. https://doi.org/10.3103/S0145875217050106.

Tichomirowa M., Whitehouse M.J., Gerdes A., Götze J., Schulz B., Belyatsky B.V., 2012. Different zircon recrystallization types in carbonatites caused by magma mixing: Evidence from $\mathrm{U}-\mathrm{Pb}$ dating, trace element and isotope composition (Hf and O) of zircons from two Precambrian carbonatites from Fennoscandia. Chemical Geology 353, 173-198. https://doi.org/10.1016/j.chemgeo.2012.11.004.

Vavra G., 1990. On the kinematics of zircon growth and its petrogenetic significance: a cathodoluminescence study. Contributions to Mineralogy and Petrology 106 (1), 90-99. https://doi.org/10.1007/BF00306410.

Veevers J.J., Belousova E.A., Saeed A., Sicombe K., Griffin W.L., Cooper A.F., Read S.E., 2006. Pan-Gondwanaland detrital zircons from Australia analysed for Hf-isotopes and trace elements reflect an ice-covered Antarctic provenance of 700-500 Ma age, T⿰м of 2.0-1.0 Ga, and alkaline affinity. Earth Science Reviews 76 (3-4), 135-174. https:// doi.org/10.1016/j.earscirev.2005.11.001.

Veevers J.J., Saeed A., Belousova E.A., Griffin W.L., 2005. U-Pb ages and source composition by Hf-isotope and traceelement analysis of detrital zircons in Permian sandstone and modern sand from southwestern Australia and a review of the paleogeographical and denudational history of the Yilgarn Craton. Earth Science Reviews 68 (3-4), 245-279. https://doi.org/10.1016/j.earscirev.2004.05.005.

Vermeesch P., 2004. How many grains are needed for a provenance study? Earth and Planetary Science Letters 224 (3-4), 351-441. https://doi.org/10.1016/j.epsl.2004.05.037.

Vermeesch P., 2012. On the visualisation of detrital age distributions? Chemical Geology 312-313, 190-194. https:// doi.org/10.1016/j.chemgeo.2012.04.021.

Villeneuve M.E., Relf C., 1998. Tectonic setting of 2.6 Ga carbonatites in the Slave Province, NW Canada. Journal of Petrology 39 (11-12), 1975-1986. https://doi.org/10.1093/petroj/39.11-12.1975.

Wanless V.D., Perfit M.R., Ridley W.I., Wallace P.J., Grimes C.B., Klein E.M., 2011. Volatile abundances and oxygen isotopes in basaltic to dacitic lavas on mid-ocean ridges: the role of assimilation at spreading centers. Chemical Geology 287 (1-2), 54-65. https://doi.org/10.1016/j.chemgeo.2011.05.017.

Watson E.B., 1996. Dissolution, growth and survival of zircons during crustal fusion: Kinetic principles, geological models and implications for isotopic inheritance. Transactions of the Royal Society of Edinburgh: Earth Sciences 87 (1-2), 43-56. https://doi.org/10.1017/S0263593300006465.

Watson E.B., Wark D.A., Thomas J.B., 2006. Crystallization thermometers for zircon and rutile. Contributions to Mineralogy and Petrology 151 (4), 413-433. https://doi.org/10.1007/s00410-006-0068-5.

Woolley A.R., 2003. Igneous silicate rocks associated with carbonatites: their diversity, relative abundances and implication for carbonatite genesis. Periodico di Mineralogia 72 (1), 9-17.

Woolley A.R., Church A.A., 2005. Extrusive carbonatites: A brief review. Lithos 85 (1-4), 1-14. https://doi.org/ 10.1016/j.lithos.2005.03.018. 
Woolley A.R., Kjarsgaard B.A., 2008. Paragenetic types of carbonatite as indicated by the diversity and relative abundances of associated silicate rocks: evidence from a global database. Geochmica et Cosmochimica Acta 46 (4), 741-752. https://doi.org/10.3749/canmin.46.4.741.

Wu F., Yang Y., Li Q., Mitchell R.H., Dawson J.B., Brandl G., Yuhara M., 2011. In situ determination of U-Pb ages and Sr-Nd-Hf isotopic constraints on the petrogenesis of the Phalaborwa carbonatite Complex, South Africa. Lithos 127 (1-2), 309-322. https://doi.org/10.1016/j.lithos.2011.09.005.

Yuan H.-L., Gao S., Dai M.-N., Zong C.-L., Gunther D., Fontaine G.H., Liu X.-M., Diwu C.-R., 2008. Simultaneous determinations of $\mathrm{U}-\mathrm{Pb}$ age, $\mathrm{Hf}$ isotopes and trace element compositions of zircon by excimer laser-ablation quadrupole and multiple-collector ICP-MS. Chemical Geology 247 (1-2), 100-118. https://doi.org/10.1016/j.chemgeo.2007.10. 003.

Zhang Sh., Li Z.-X., Evans D.A.D., Wu H., Li H., Dong J., 2012. Pre-Rodinia supercontinent Nuna shaping up: A global synthesis with new paleomagnetic results from North China. Earth and Planetary Science Letters 353-354, 145-155. https://doi.org/10.1016/j.epsl.2012.07.034.

Zhao G., Cawood P.A., Wilde S.A., Sun M., 2002. Review of global 2.1-1.8 Ga orogens: Implications for a pre-Rodinia supercontinent. Earth-Science Reviews 59 (1-4), 125-162. https://doi.org/10.1016/S0012-8252(02)00073-9.

Zhao G., Suna M., Wilde S.A., Li S., 2004. A Paleo-Mesoproterozoic supercontinent: assembly, growth and breakup. Earth-Science Reviews 67 (1-2), 91-123. https://doi.org/10.1016/j.earscirev.2004.02.003.

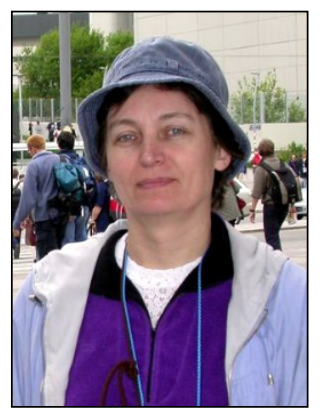

Татьяна Валентиновна Романюк, докт. физ.-мат. наук, г.н.с.

Институт физики Земли им. О.Ю. Шмидта РАН

123242, ГСП-5, Москва Д-242, ул. Большая Грузинская, 10, Россия

Российский государственный университет нефти и газа (национальный исследовательский университет) им. И.М. Губкина

119991, Москва, Ленинский проспект, 65, корпус 1, Россия

Университет Маквори / центр CCFS/GEMOK, Сидней, Австралия

12 Wally's Walk, Sydney, NSW 2109, Australia

Тел.: (499)2542327; \ e-mail: t.romanyuk@mail.ru

Tatiana V. Romanyuk, Doctor of Physics and Mathematics, Chief Researcher

O.Yu. Schmidt Institute of Physics of the Earth of RAS

10 Bol'shaya Gruzinskaya street, Moscow D-242 123242, GSP-5, Russia

I.M. Gubkin Russian State University of Oil and Gas (National Research University)

Building 1, 65 Leninsky Ave., Moscow 119991, Russia

Australian Research Council Centre of Excellence for Core to Crust Fluid Systems/GEMOC,

Department of Earth and Planetary Sciences, Macquarie University

12 Wally's Walk, Sydney, NSW 2109, Australia

Tel.: (499)2542327; \ e-mail: t.romanyuk@mail.ru

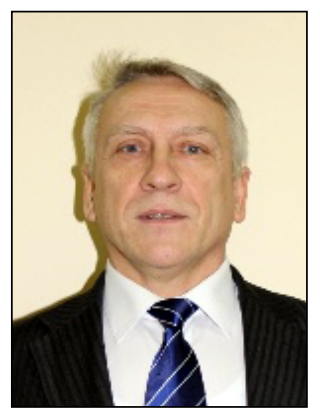

Николай Борисович Кузнецов, докт. геол.-мин. наук, заместитель директора

Геологический институт РАН

119017, Москва, Пыжевский пер., 7, Россия

Институт физики Земли им. О.Ю. Шмидта РАН

123242, ГСП-5, Москва Д-242, ул. Большая Грузинская, 10, Россия

Российский государственный университет нефти и газа (национальный

исследовательский университет) им. И.М. Губкина

119991, Москва, Ленинский проспект, 65, корпус 1, Россия

Университет Маквори / центр CCFS/GEMOK, Сидней, Австралия

12 Wally's Walk, Sydney, NSW 2109, Australia

Тел.: (495)9533951; e-mail: kouznikbor@mail.ru

Nikolai B. Kuznetsov, Doctor of Geology and Mineralogy, Deputy Director

Geological Institute of RAS

7 Pyzhevsky Lane 7, Moscow 119017, Russia

O.Yu. Schmidt Institute of Physics of the Earth of RAS

10 Bol'shaya Gruzinskaya street, Moscow D-242 123242, GSP-5, Russia

I.M. Gubkin Russian State University of Oil and Gas (National Research University)

Building 1, 65 Leninsky Ave., Moscow 119991, Russia

Australian Research Council Centre of Excellence for Core to Crust Fluid Systems/GEMOC,

Department of Earth and Planetary Sciences, Macquarie University

12 Wally's Walk, Sydney, NSW 2109, Australia

Tel.: (495)9533951; e-mail: kouznikbor@mail.ru 

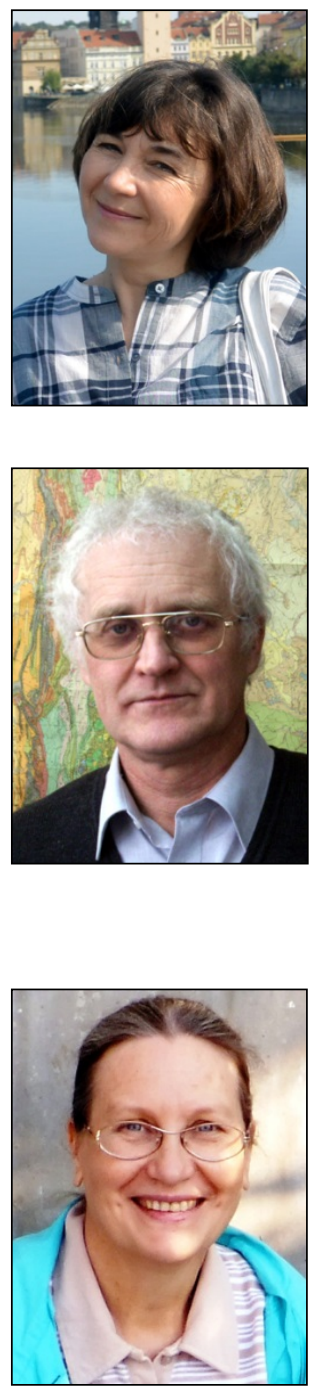

Елена Алимовна Белоусова, $\mathrm{PhD}$

Университет Маквори / центр CCFS/GEMOK, Сидней, Австралия

Room 224, 12 Wally's Walk, Sydney, NSW 2109, Australia

Тел.: +61 29850 6126; e-mail: elena.belousova@mq.edu.au

Elena A. Belousova, $\mathrm{PhD}$

Australian Research Council Centre of Excellence for Core to Crust Fluid Systems/GEMOC, Department of Earth and Planetary Sciences, Macquarie University

Room 224, 12 Wally's Walk, Sydney, NSW 2109, Australia

Tel.: +61 29850 6126; e-mail: elena.belousova@mq.edu.au

Валерий Михайлович Горожанин, канд. геол.-мин. наук, заведующий лабораторией Институт геологии Уфимского научного центра РАН

450077, Уфа, ул. Карла Маркса, 16/2, Россия

Башкирский государственный университет

450076, Уфа, ул. Заки Валиди, 32, Россия

Тел.: (347)2728256; e-mail: gorozhanin@ufaras.ru

Valery M. Gorozhanin, Candidate of Geology and Mineralogy, Head of Laboratory

Institute of Geology of the Ufa Federal Research Centre of RAS

16/2 Karl Marx street, Ufa 450077, Russia

Bashkir State University

32 Zaki Validy Street, Ufa 450076, Russia

Tel.: (347)2728256; e-mail: gorozhanin@ufaras.ru

Елена Николаевна Горожанина, канд. геол.-мин. наук, с.н.с.

Институт геологии Уфимского научного центра РАН

450077, Уфа, ул. Карла Маркса, 16/2, Россия

Тел.: (347)2728256; e-mail: ygorozhanina@yandex.ru

Elena N. Gorozhanina, Candidate of Geology and Mineralogy, Senior Researcher Institute of Geology of the Ufa Federal Research Centre of RAS

16/2 Karl Marx street, Ufa 450077, Russia

Tel.: (347)2728256; e-mail: ygorozhanina@yandex.ru 